Kelly Regina Torres

\title{
DISTRIBUIÇÃO DA TENEURINA-1 (TEN 1) E DO PEPTÍDEO ASSOCIADO AO TERMINAL CARBOXILA DA TENEURINA-1 (TCAP- 1) NOS NEURÔNIOS DO SISTEMA NERVOSO CENTRAL DE PRIMATA NÃO-HUMANO (Cebus apella)
}

Dissertação apresentada ao Programa de PósGraduação em Ciências Morfofuncionais do Instituto de Ciências Biomédicas da Universidade de São Paulo para obtenção do Título de Mestre em Ciências.

São Paulo

2012 
Kelly Regina Torres

\section{DISTRIBUIÇÃO DA TENEURINA-1 (TEN 1) E DO PEPTÍDEO ASSOCIADO AO TERMINAL CARBOXILA DA TENEURINA-1 (TCAP-1) NOS NEURÔNIOS DO SISTEMA NERVOSO CENTRAL DE PRIMATA NÃO-HUMANO (Cebus apella)}

Dissertação apresentada ao Programa de PósGraduação em Ciências Morfofuncionais do Instituto de Ciências Biomédicas da Universidade de São Paulo para obtenção do Título de Mestre em Ciências.

Área de concentração: Ciências Morfofuncionais.

Orientador: Prof. Dr. Cláudio Aparecido Casatti

Versão original

São Paulo

2012 
DADOS DE CATALOGAÇĀO NA PUBLICAÇĀO (CIP)

Serviço de Biblioteca e Informação Biomédica do

Instituto de Ciências Biomédicas da Universidade de São Paulo

(C) reproduçāo total

Torres, Kelly Regina.

Distribuiçāo da teneurina-1 (TEN 1) e do peptídeo associado ao terminal carboxila da teneurina-1 (TCAP-1) nos neurônios do sistema nervoso central de primata não-humano (Cebus apella) / Kelly Regina Torres. -- São Paulo, 2012.

Orientador: Cláudio Aparecido Casatti.

Dissertação (Mestrado) - Universidade de São Paulo. Instituto de Ciências Biomédicas. Departamento de Anatomia. Área de concentração: Ciências Morfofuncionais. Linha de pesquisa: Neuroanatomia.

Versão do título para o inglês: Distribution of teneurin (TEN 1) and teneurin-1 C-terminal associated peptide (TCAP-1) in neurons of the central nervous system of non-human primates (Cebus apella)

Descritores: 1. Macaco 2. Fator liberador da corticotropina 3. Estresse 4. Neuropeptídeos I. Casatti, Cláudio Aparecido II. Universidade de São Paulo. Instituto de Ciências Biomédicas. Programa de Pós-Graduação em Ciências Morfofuncionais III. Título. 
Candidato(a):

Título da Dissertação:

Orientador(a):
Kelly Regina Torres.

Distribuição da teneurina-1 (TEN 1) e do peptídeo associado ao terminal carboxila da teneurina-1 (TCAP-1) nos neurônios do sistema nervoso central de primata nãohumano (Cebus apella).

Cláudio Aparecido Casatti.

A Comissão Julgadora dos trabalhos de Defesa da Dissertação de Mestrado, em sessão pública realizada a ...................................,
( ) Aprovado(a)
( ) Reprovado(a)

Examinador(a): Assinatura:

Nome completo:

Instituição:

Examinador(a): Assinatura:

Nome completo:

Instituição:

Presidente: Assinatura:

Nome completo:

Instituição: 


\section{Certificado}

Certificamos que o protocolo registrado sob $\mathrm{n}^{\circ} 109$ nas fls. 75 do livro 02 para uso de animais em experimentação, sob a responsabilidade do Prof(a) Dr(a) Jackson Cioni Bittencourt, Coordenador(a) da Linha de pesquisa Distribuiçâo dos neurônios que expressam a teneurina 1 (TEN-1) e o peptideo associado ao terminal carboxila da teneurina1 (TCAP-1) no sistema nervoso central de primata do qual participou(aram) o(s) alunos Kelly Regina Torres, está de acordo com os Principios Etícos de Experimentaçăo Animal adotado pela Sociedade Brasileira de Ciência de Animais de Laboratório (SBCAL) e foi aprovado pela COMISSÁO DE ÉTICA NO USO DE ANIMAIS (CEUA) em 02.12.09, com validade de 3 anos.
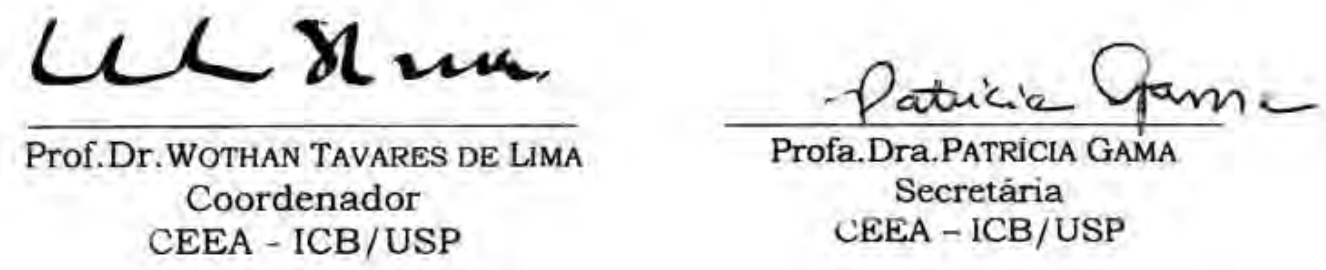


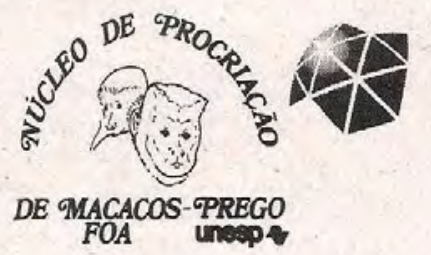

NÚCLEO DE PROCRIAÇÃO DE MACACOS-PREGO

Faculdade de Odontologia do Campus de Araçatuba Departamento de Clência Básicas

\section{DECLARAÇÃO}

Declaro, para todos os fins, que o Núcleo de Procriação de Macacos-Prego do Departamento de Ciências Básicas desta Faculdade, analisou e autorizou o desenvolvimento do projeto de pesquisa "Distribuição das teneurinas e dos peptídeos associados ao terminal carboxila das teneurinas (TCAP) em macacos-prego (Cebus apella)", sob a responsabilidade do Professor Doutor Claudio A Casatti, por estar de acordo com as normas de cessão de macacos, de que trata a Portaria FOA 087/95. Acrescento que os encéfalos foram removidos de animais já utilizados em pesquisa desenvolvida anteriormente, cujo parecer favorável foi emitido por este Núcleo.

A manipulação dos animais seguiu o protocolo de rotina empregado neste Núcleo, com os seguintes procedimentos:

1) Captura e Anestesia: os macacos foram capturados das gaiolas individuais, pré-anestesiados com injeção intramuscular de cloridrato de cetamina $(10 \mathrm{mg} / \mathrm{Kg}$ peso corporal) e anestesiados através de uma injeção intraperitoneal de tiopental sódico (30 $\mathrm{mg} /$ quilograma de peso corporal). Injeção in ramuscular de diazepínico, na dosagem de 0,3 $\mathrm{mg} /$ quilograma de peso corporal, compleme itou os procedimentos de anestesia.

2) Sacrifício e perfusão: os mesmos procedimentos para captura e anestesia e perfusão via intracardíaca de líquidos fixadores por meio de uma bomba peristáltica.

Informamos que este Núcleo atende às disposições básicas contidas no "Guide to the Care and Use of Experimental Animals", vols 1 e 2, do Canadian Council on Animal Care, bem como a normativas dispostas na Portaria 016/94 do IBAMA.

Araçatuba, 01 de julho de 2008.

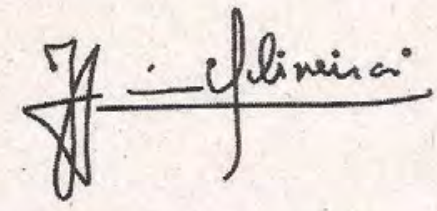

José Américo de Oliveira

Responsável pelo

Núcleo de Procriação de Macacos-Prego do

Departamento de Ciências Básicas da

Facu 'dade de Odontologia do Campus de Araçatuba

UNESP 


\title{
À Deus...
}

Suas bênçãos e o Sew amor por mim é que me sustenta a cada dia para ter $\sigma$ ânimo de enfrentar, com muita felicidade, as tristezas e desafios de cada día.

\author{
Aos mens pais...
}

Osmar Torres e Sônia A. F. Torres dedico todo $\sigma$ mew carinho e amor. Obrigada por estarem sempre ao meu lado e por terem construido nossa familia tão linda que é sempre mew maior exemplo e orgutho.

\section{Ao mew irmão, cunhada e sobrinha...}

Cléber R. Torres e María Lúcia C. Torres que sempre me apoiarame orientaram nas minhas decisóes. À minha querida sobrinha Isabella, lindo anjinho que enche de alegria a toda familia.

\section{Ao meu amado noivo...}

André $V$. da Silva que sempre está ar meu lado dedicando sew amor. Obrigada pela sua preciosa paciência, compreensão e incentivo. Dedico a você essa nossa conquista e o mew amor. 


\section{AGRADECIMENTOS}

Ao meu orientador Prof. Dr. Cláudio Aparecido Casatti por ter acreditado e incentivado o meu trabalho desde a iniciação científica;

Ao Prof. Dr. Jackson Cioni Bittencourt por ter oferecido a mim seus conhecimentos bem como toda a infra-estrutura de seu laboratório (Laboratório de Neuroanatomia Química);

Ao Dr. David Lovejoy da Universidade de Toronto que, gentilmente, concedeu os anticorpos e peptídeos utilizados para TCAP-1, além de sempre debater e auxiliar no esclarecimento dos nossos resultados;

Aos colegas do Laboratório de Neuroanatomia Química: Profa. Dra. Luciane V. Sita pela colaboração científica; Joelcimar Martins da Silva e Amanda Ribeiro de Oliveira pelo suporte técnico e pós-graduandos pela discussões científicas;

Ao programa de pós-graduação em Ciências Morfofuncionais que nesta gestão é coordenado pela Profa Dra. Maria Luiza M. B. de Chaves; Prof. Dr. Newton S. Canteras e Profa. Dra. Maria Inês Nogueira;

Ao prof. Dr. José Américo de Oliveira da Faculdade de Odontologia de Araçatuba - UNESP, pela amizade e contribuição neste trabalho e ao núcleo de procriação de macacos prego, competentemente dirigido por este mestre;

Aos professores e aos técnicos do departamento de Ciências Básicas da Faculdade de Odontologia de Araçatuba - UNESP que sempre me acompanham ao longo da minha vida acadêmica e que fazem a nossa convivência ser muito prazerosa;

Aos funcionários da segurança do Departamento de Anatomia do Instituto de Ciências Biomédicas da Universidade de São Paulo - USP que além de garantirem a segurança pública esbanjam alegria e prazer em realizar sua profissão; 
Aos funcionários da secretaria de pós-graduação do Departamento de Anatomia do Instituto de Ciências Biomédicas da Universidade de São Paulo - USP, em especial à Patrícia Rodrigues de Campos, pela excelente dedicação ao trabalho e paciência em atender;

Aos funcionários da Biblioteca do Instituto de Ciências Biomédicas da Universidade de São Paulo - USP pela rapidez e dedicação na prestação de auxílios;

À senhora Terezinha Faquin e ao senhor Sebastião Corrêa agradeço muito o carinho e acolhida que sempre é dado a mim e que me fazem ter a certeza de que ganhei mais uma família;

À minha amiga Daniella Sabino Batagello que em muitos momentos me amparou e me deu coragem em seguir em frente; e aos amigos de laboratório Carlos Alexandre e Sílvia Honda por todo o conhecimento oferecido e acima de tudo pela verdade e amizade a mim dedicada;

À Fundação de Amparo a Pesquisa do Estado de São Paulo - FAPESP - por ter financiado este projeto: 2009/11026-5 e à Coordenação de Aperfeiçoamento de Pessoal de nível Superior - CAPES - por financiar o programa de pós-graduação em Ciências Morfofuncionais. 
"Enquanto houver vontade de lutar haverá esperança de vencer" (Santo Agostinho) 


\section{RESUMO}

Torres KR. Distribuição da teneurina-1 (TEN 1) e do peptídeo associado ao terminal carboxila da teneurina-1 (TCAP-1) nos neurônios do sistema nervoso central de primata nãohumano (Cebus apella). [Dissertação (Mestrado em Ciências Morfofuncionais)]. São Paulo: Instituto de Ciências Biomédicas da Universidade de São Paulo; 2012.

As teneurinas (TENs) são uma família de proteínas de transmembrana constituídas de quatro homólogos nos vertebrados e com significante expressão no sistema nervoso central (SNC). A análise do último éxon dos genes de cada teneurina exibe uma sequência que codifica um peptídeo com elevada identidade com a família de peptídeos do fator liberador de corticotropina (CRF). Estes peptídeos são nomeados de peptídeos associado ao terminal carboxila das teneurinas (TCAP-1 a 4). Estudos in vivo e in vitro têm mostrado que os TCAPs, em especial TCAP-1, exibe potente ação sobre o controle comportamental associado ao estresse, possivelmente por modular as ações mediadas pelo (CRF). A análise da distribuição deste peptídeo no SNC de primatas não-humanos poderia subsidiar o entendimento de seus efeitos funcionais, assim como de suas possíveis aplicações terapêuticas. Portanto, o presente trabalho visou analisar a imunorreatividade (ir) da TEN 1 e do TCAP-1 bem como a expressão do RNA mensageiro (RNAm) do TCAP-1 no encéfalo de primatas não-humanos (Cebus apella). Cortes histológicos frontais do neuroeixo de macacos da espécie Cebus apella $(\mathrm{n}=3)$ foram selecionados e utilizados nas técnicas de hibridização in situ e de imuno-histoquímica. Os neurônios imunorreativos ao TCAP-1 estavam principalmente distribuídos no córtex cerebral (motor e sensorial), cerebelo (células de Purkinje e núcleos cerebelares), hipocampo (CA1-CA4), amígdala, núcleo basal (Meynert), núcleo supra-óptico, além de outras regiões diencefálicas e do tronco encefálico. Os resultados de hibridização in situ confirmaram a expressão do TCAP-1 nas regiões citadas. Os resultados da imunorreatividade para TEN 1 mostram que a diferença entre TCAP-1 e TEN 1 , aparentemente, se encontra no padrão de marcação e não na distribuição neuroanatômica que mostra-se correspondente em muitas regiões encefálicas. Estes resultados demonstraram que TEN 1 e TCAP-1 está conservada nos primatas, sendo que TCAP-1 encontra-se principalmente em áreas que estão direta ou indiretamente envolvidas na modulação da resposta ao estresse e ansiedade.

Palavras-chaves: Macaco, Fator liberador da corticotropina, Estresse, Neuropeptídeos. 


\begin{abstract}
Torres KR. Distribution of teneurin-1 (TEN 1) and teneurin-1 c-terminal associated peptide (TCAP-1) in neurons of the central nervous system of non-human primates (Cebus apella). [Master Thesis]. São Paulo: Instituto de Ciências Biomédicas da Universidade de São Paulo; 2012.
\end{abstract}

Teneurins are transmembrane proteins constituted by four homologous in vertebrates, expressed mainly in the central nervous system (CNS). The last exon of the teneurins exhibits a peptide sequence with high homology to corticotrophin-releasing factor (CRF), named teneurin c-terminal associated peptide (TCAP-1 to 4). TCAP-1 effectively modulates stress induced by CRF. In vivo and in vitro studies have pointed tha TCAP-1 could have important therapeutic applications in stress disorders. The analysis of TCAP-1 distribution in the primate brain could also give anatomical support to the understanding of its functional effects and possible therapeutic use. Thus, the present study focused on the distribution of neurons exhibiting immunoreactivity to TEN 1 and TCAP-1 and mRNA expression to TCAP-1 in the monkey brain (Cebus apella). Frontal brain sections of three young male Cebus apella monkeys were sectioned in freezing microtome and one series was submitted to immunohistochemistry and other series to in situ hybridization. The results of immunohistochemistry revealed neurons immunoreactive to TCAP-1 mainly distributed in the cerebral cortex (motor and sensorial), cerebellum (Purkinje cells and cerebelar nuclei), hippocampus (CA1-CA4), amygdala, basal nucleus (Meynert), supraoptic nucleus, besides several other diencephalic and brainstem regions. The in situ hybridization confirmed the TCAP-1 expression in those regions of the central nervous system. The results of immunoreactivity to TEN 1 showed difference with TCAP-1 in labeling pattern and not in neuroanatomical distribution. Our results demonstrated that the distribution of TEN 1 and TCAP-1 is preserved in the non-human primate brain. In addition, most areas tha express TCAP-1 are directly or indirectly involved in stress and anxiety modulation.

Keywords: Monkey, Corticotrophin-releasing factor, Stress, Neuropeptides. 


\section{LISTA DE ILUSTRAÇÕES}

Figura 1 - Análise do modelo estrutural e da organização gênica da TEN 1

Figura 2 - Análise filogenética entre a família de peptídeos do CRF e TCAPs

Figura 3 - Análise da identidade entre as sequências de TCAP-1 do Cebus apella com primatas não humanos e humanos, aves, roedores e anfíbios, através do software BLAST

Figura 4 - Representação esquemática da sequência da fita de DNA do plasmídeo juntamente com a representação da fita do inserto de DNA para TCAP-1 do Cebus

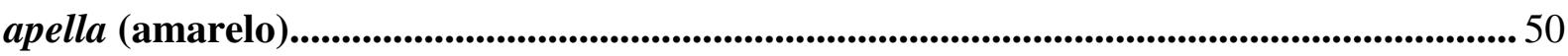

Figura 5 - Teste de titulação do anticorpo primário para TCAP-1. ................................ 52

Figura 6 - Teste de titulação do anticorpo primário para TEN 1................................... 53

Figura 7 - Teste de adsorção do anticorpo primário para TCAP-1................................... 55

Figura 8 - Fotografias macroscópicas do encéfalo do Cebus apella ...................................... 64

Figura 9 - Análise dos filmes radiográficos após hibridização in situ para TCAP-1 ....... 65

Figura 10 - Distribuição dos neurônios TCAP-1 imunorreativos em regiões telencefálica

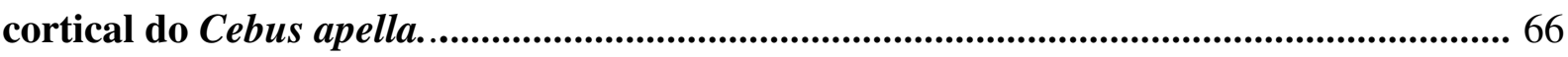

Figura 11 - Distribuição dos neurônios TCAP-1 imunorreativos em regiões telencefálica

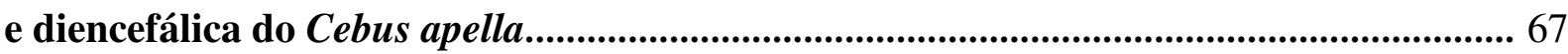

Figura 12 - Imunorreatividade e expressão do RNAm para TCAP-1 no núcleo horizontal da banda diagonal (HDB) ........................................................................................................ 68

Figura 13 - Imunorreatividade e expressão do RNAm para TCAP-1 no núcleo geniculado lateral dorsal (DLG) ..................................................................................................................... 69

Figura 14 - Imunorreatividade e expressão do RNAm para TCAP-1 no núcleo supra-

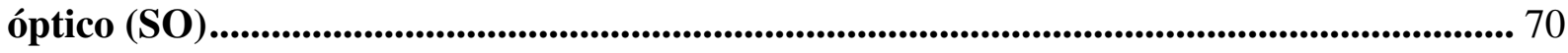


Figura 15 - Distribuição dos neurônios TCAP-1 imunorreativos em regiões do tronco encefálico do Cebus apella ........................................................................................................... 71

Figura 16 - Imunorreatividade e expressão do RNAm para TCAP-1 na substância

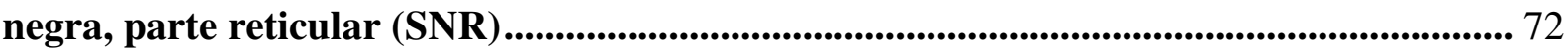

Figura 17 - Distribuição dos neurônios TCAP-1 imunorreativos em regiões do cerebelo

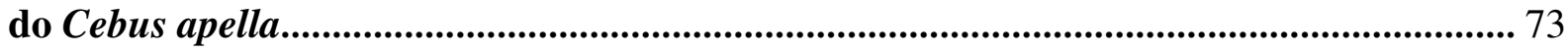

Figura 18 - Desenho representativo da distribuição do TCAP-1 em algumas regiões do sistema nervoso central (SNC) do Cebus apella .................................................................. 74

Figura 19 - Padrão de imunorreatividade e co-localização da TEN 1 e TCAP-1............ 76 


\section{LISTA DE TABELAS}

Tabela 1 - Análise dos aminoácidos que compõe os peptídeos das famílias do CRF e dos TCAPs em humanos

Tabela 2 - Característica da competição do peptídeo TCAP-1 no SNC do Cebus apella através do teste de adsorção ..........................................................................................................56

Tabela 3 - Distribuição do peptídeo e RNAm para TCAP-1 no SNC do Cebus apella .... 62 


\section{LISTA DE ABREVIATURAS E SIGLAS} "RNase free" - ausência de
enzimas ribonucleases

$\triangle \mathrm{NTP}$ - mistura de CTP, GTP,

ATP e água

$\mu \mathrm{Ci}-$ microcurie

$\mu \mathrm{g}-$ micrograma

$\mu \mathrm{L}$ - microlitro

$\mu \mathrm{m}$-micrômetro

${ }^{35} \mathrm{~S}$ - enxofre radioativo 35

3a - área 3a do córtex

somatossensorial

3b - área 3b do córtex

somatossensorial

$3 \mathrm{~V}$ - terceiro ventrículo

4 (F1) - área 4 do córtex (motor primário)

$6 \mathrm{~N}$ - núcleo do nervo abducente

9L - área 9 do córtex, parte lateral

9M - área 9 do córtex, parte medial

AA - área amigdalóide anterior

ABC- complexo avidina

biotina

acp - comissura anterior, pós límbica

AHi -área amigdalohipocampal

AMPc - adenosina monofosfato cíclico

B - núcleo basal (Meynert)
CA1 - camada CA1 do hipocampo

CA2 - camada CA2 do hipocampo

CA3 - camada CA3 do hipocampo

CA4 - camada CA4 do hipocampo

Cb6 - lóbulo cerebelar 6

cc - corpo caloso

cDNA -ácido

desoxirribonucleico

complementar

Ce - núcle central da amígdala

cgs - sulco cingulado

CNEN - comissão nacional de energia nuclear

cp- pendúnculo cerebral

$\mathrm{cpm} / \mathrm{ml}$ - contagem por minuto por $\mathrm{ml}$

CRF- fator liberador de corticotropina

cRNA - ácido ribonucléico mensageiro complementar

Crus 1- crus 1 do lóbulo ansiforme

Crus 2- crus 2 do lóbulo ansiforme

cs - sulco central

ctg- trato tegmental central

DAB - tetracloreto de diaminobenzidina
DC - núcleo coclear dorsal

DEPC- dietilpirocarbonato

DLG - núcleo geniculado lateral dorsal

DMSO - dimetilsulfóxido

DNA - ácido

desoxirribonucléico

DNase- enzimas

desoxirribonuclease

DPFl - lóbulo paraflocular dorsal

DTT - ditiotreitol

E. coli-Escherichia coli

ecal- sulco calcarino externo

EDTA - ácido etilenodiamino tetra-acético

EGF_-"epidermal growth factor-like"

EGP - globo pálido externo

F. Hip.- formação hipocampal

fos - "sarcoma finkel osteogenic"

Gr - núcleo grácil

$\mathrm{GrCb}$ - camada granular do cerebelo

$\mathrm{H}_{2} \mathrm{O}_{2}$ - peróxido de hidrogêneo

HDB - núcleo horizontal da banda diagonal

HIS- hibridização in situ

i.c.v. - intracerebroventricular 
iar- sulco arqueado inferior

IBAMA- instituto brasileiro do meio ambiente

If - fissura lateral

IGP - globo pálido interno

IntA - núcleo interpósito anterior do cerebelo

IntP - núcleo interpósito posterior do cerebelo

IOC. - complexo olivar inferior

IOD- núcleo olivar inferior

dorsal

IOPr - núcleo principal inferior da oliva

ios - sulco occipital inferior

ir - imunorreatividade

kDa - kilodalton

KPBS - tampão fosfato potássio de sódio

Lat - núcleo lateral do cerebelo

LB - meio de cultura LuriaBroth

LH- área hipotalâmica lateral

LM - núcleo mamilar lateral

LRt - núcleo reticular lateral

LV- ventrículo lateral

MAO - núcleo olivar acessório medial

Me - núcleo medial da amígdala

Med - núcleo cerebelar medial

Mesenc.- mesencéfalo
MoCb - camada molecular do cerebelo

$\mathrm{mV}$ - milivolts

N. base - núcleos da base

N. cerebelo - núcleos do cerebelo

NAS - sulfato níquel amônia

NC - núcleos cocleares

opt -trato óptico

pbs - pares de bases

PBS - tampão fostafo de sódio

PCR- reação da polimerase em cadeia

pH - potencial hidrogeniônico

PH- área hipotalâmica posterior

Pk - camada de Purkinje do cerebelo

Pn - núcleo pontino

PnR - núcleo pontino da rafe

pos - parietooccipital

PPFI - lóbulo paraflocular posterior

Pr5 - núcleo principal do trigêmio

PrG- núcleo pré-geniculado

ps -sulco principal

RNAm - ácido ribonucléico mensageiro

RNases - enzimas

ribonucleases

RNasin - inibidor de RNase

$\mathrm{ROb}$ - núcleo obscuro da rafe rpm - rotação por minuto

RRF- campo retrorubral

RT-PCR - reação em cadeia da polimerase via transcriptase reversa

sar- sulco arqueado superior

Sept.- área septal

SIB - substância inominata, parte basal

Sim - lóbulo simples

SN - substância negra

SNC - sistema nervoso central

snc- subtancia negra, parte

compacta

SNL - substância negra, parte lateral

SNR - substância negra, parte reticular

SO - núcleo supra-óptico

Sp5 - núcleo espinal do trigêmio

Sp5i - núcleo espinal do trigêmio, parte interpolar

SSC - tampão citrato de sódio

STh- núcleo subtalâmico

sts - sulco temporal superior

TAE - tris-acetato EDTA

Tal.- núcleos talâmicos

TCAP-1- peptídeo associado ao terminal carboxila da teneurina-1

TCAP-1-ir - imunorreativo ao TCAP-1 
TCAPs - peptídeos associados ao terminal carboxila das teneurinas

TEA-HCL - trietanolaminaácido clorídrico

Telu- tampão de eluição

TEN 1 - teneurina-1

TEN 1-ir - imunorreativo a teneurina-1

TEN 2 - teneurina-2

TEN 3 - teneurina-3

TEN 4 - teneurina-4

Ten-a - "tenascin-like protein accessory"
Ten-m- "tenascin-like protein major"

TENs - teneurinas

Teq - tampão de equilíbrio

TH - tampão de hibridização

Tlav - tampão de lavagem

Tlise - tampão de lise

Tneutr - tampão de neutralização

Tsusp - tampão de suspensão celular

$\mathrm{U} / \mu \mathrm{l}$ - unidade por microlitro

UCN 1 - urocortina-1

UCN 2 - urocortina-2
UCN 3- urocortina-3

UTP - trifosfato de uracila

VCA - núcleo coclear, parte anterior

VCP - núcleo coclear, parte posterior

VDB - núcleo vertical da banda diagonal

VP - pálido ventral

ZI- zona incerta 


\section{LISTA DE SÍMBOLOS}

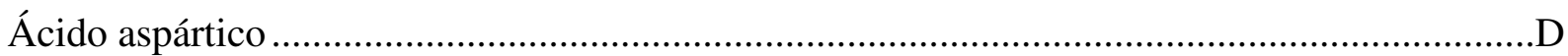

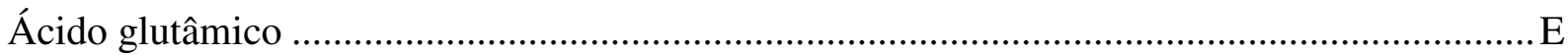

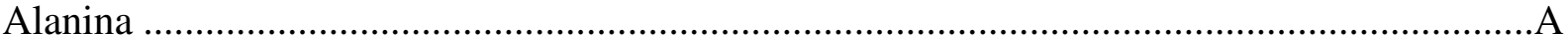

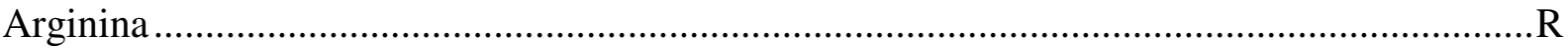

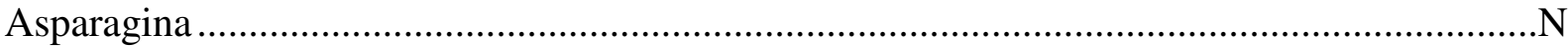

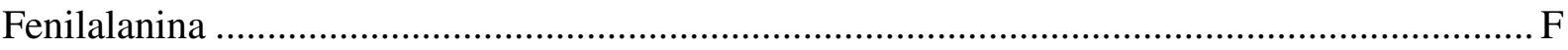

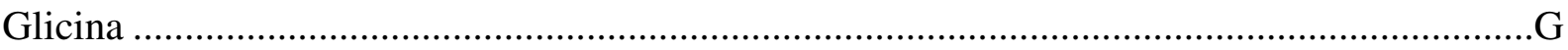

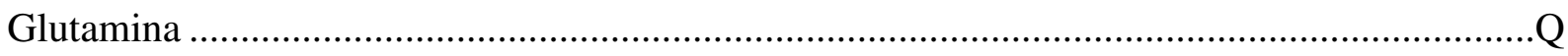

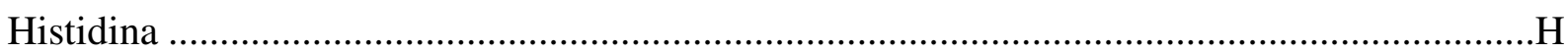

Isoleucina

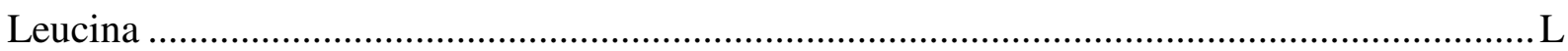

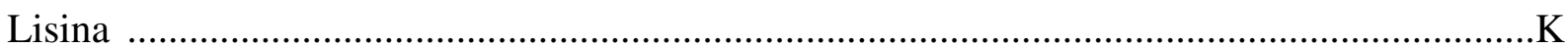

Metionina

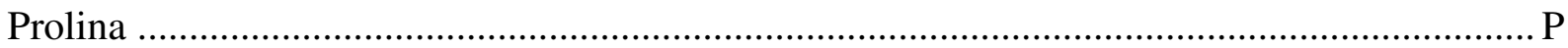

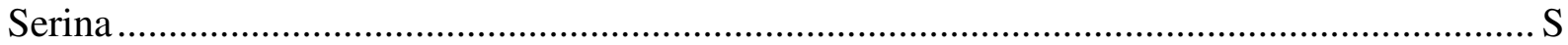

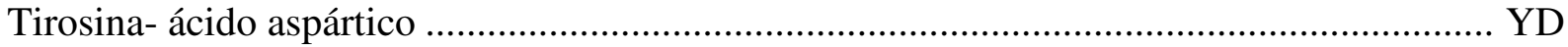

Tirosina

Treonina

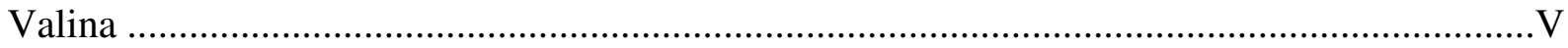




\section{SUMÁRIO}

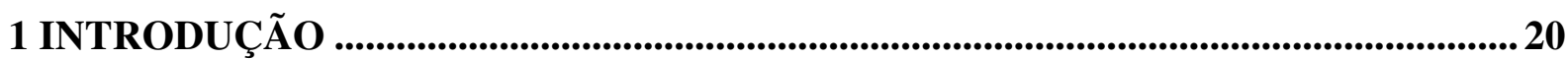

2 JUSTIFICATIVA ……................................................................................................................. 28

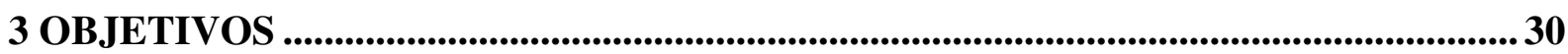

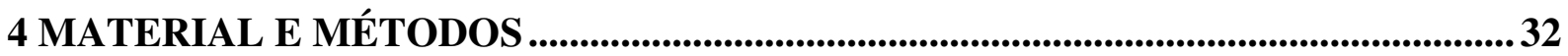

4.1 Cebus apella .........................................................................................................................................33

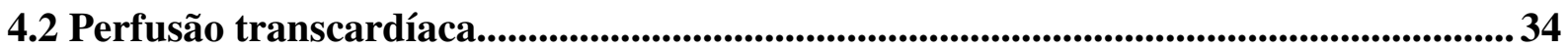

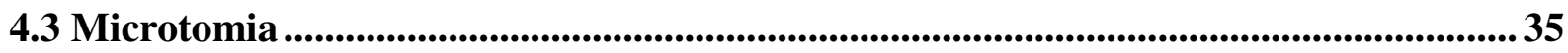

4.4 Hibridização in situ .......................................................................................................................36

4.4.1 Análise das sequências do TCAP-1 do Cebus apella .................................................. 36

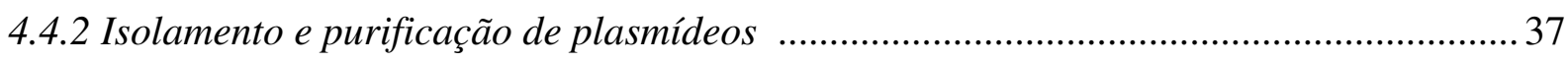

4.4.3 Linearização do plasmídeo e transcrição in vitro............................................................ 38

4.4.4 Pré-tratamento (desproteinização e neutralização dos tecidos)...................................... 40

4.4.5 Hibridização e pós-hibridização .............................................................................. 41

4.5 Coloração pela técnica de Nissl (tionina $0,25 \%$ )................................................................. 42

4.6 Técnica de imuno-histoquímica pelo método de imunoperoxidase indireta................. 42

4.7 Técnica de imuno-histoquímica pelo método de dupla imuno-fluorescência ............... 45

4.8 Forma de análise dos resultados, aquisiçãa e edição das imagens .....................................46

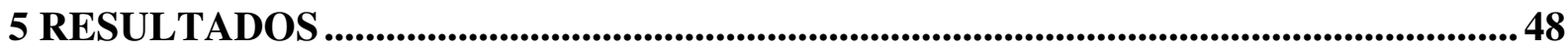

5.1 Procedimentos controles .............................................................................................................. 49

5.1.1 Hibridização in situ: análise das sequências do TCAP-1 do Cebus apella ..................... 49

5.1.2 Imuno-histoquímica: teste de titulação ……………………………………….......... 51 
5.2 Análise dos cortes histológicos submetidos à hibridização in situ e imuno-

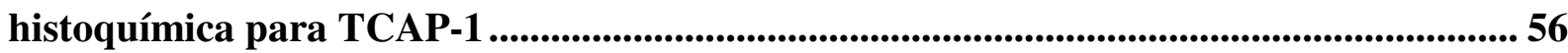

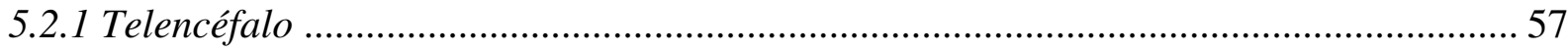

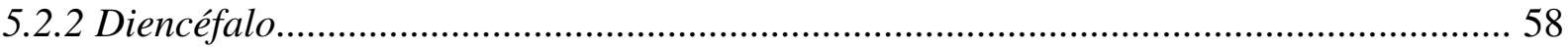

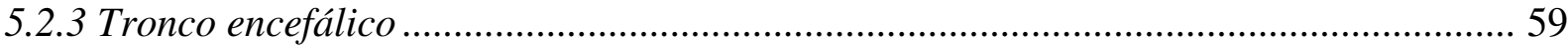

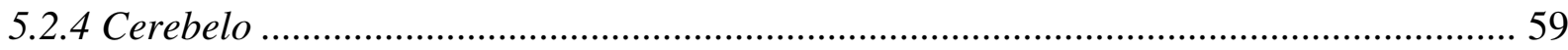

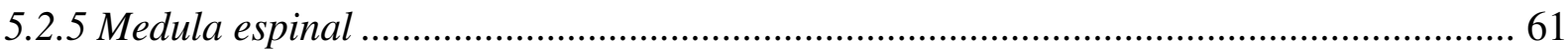

5.3 Distribuição do TCAP-1 e TEN 1 no SNC do Cebus apella .........................................75

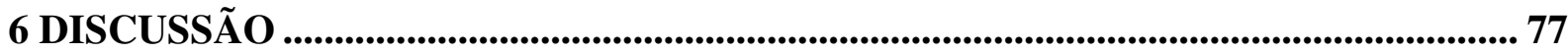

6.1 Considerações sobre o controle da técnica de imuno-histoquímica................................ 78

6.2 Considerações sobre o padrão de marcação ............................................................................. 79

6.3 Considerações a especificidade da sonda ...................................................................................... 79

6.4 Considerações comparativas: neuroanatômicas e funcionais do TCAP-1 em roedores

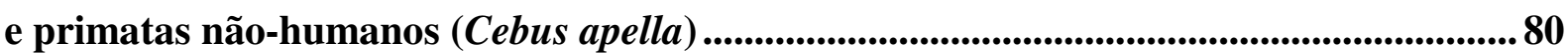

6.5 Considerações neuroanatômicas e funcionais da distribuição de TCAP-1 em primatas não-humanos (Cebus apella $)$.......................................................................................................8 82

6.6 Considerações sobre a distribuição de TEN 1/TCAP-1 em primatas não-humanos

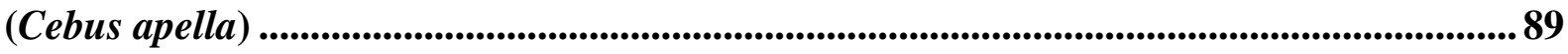

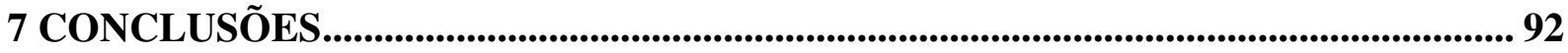
REFERÊNCIAS 
As teneurinas (TENs) são uma nova família de proteínas transmembrana, descritas inicialmente em Drosophila melanogaster como Ten-a ("tenascin-like protein accessory") e Ten-m (“tenascin-like protein major”) (Baumgartner e Chiquet-Ehrismann, 1993; Baumgartner et al., 1994) apresentando estas identidade estrutural com as tenascinas que são proteínas da matriz extracelular de vertebrados. Posteriormente, foi verificado que essa família de proteínas é composta por quatro membros nos cordados sendo estes denominados de teneurina-1 a 4 (TEN 1-4) e por um membro em nematelmintos denominado de ten-1 (Oohashi et al., 1999; Minet e Chiquet-Ehrismann, 2000; Zhou et al., 2003; Drabikowski, Trzebiatowska e Chiquet-Ehrismann, 2005). Além da expressão conservada entre as espécies, as teneurinas estão presentes principalmente nos neurônios do sistema nervoso central (SNC) dessas mesmas espécies (Minet et al., 1999; Oohashi et al., 1999; Minet e Chiquet-Ehrismann, 2000; Tucker e Chiquet-Ehrismann, 2006; Tucker et al., 2007). Com base nessas interessantes características foi que Minet et al. (1999) sugeriram o nome a essa família de proteínas transmembrana de "teneurinas" (ten: tenascinas; neurina: neurônios).

Estruturalmente, todos os membros da família das TENs compartilham de características comuns, exibindo peso molecular de aproximadamente $300 \mathrm{kDa}$ e constituição entre 2500 a 2800 aminoácidos. A análise da identidade mostra que entre os vertebrados as TENs apresentam de $60 \%$ a $98 \%$ de sequências de aminoácidos idênticos; enquanto que as TENs de vertebrados e invertebrados apresentam 33\% a $41 \%$ de sequências de aminoácidos idênticos, revelando a consistente conservação dessa família de proteínas. As TENs são classificadas como proteínas transmembrana do tipo II, pois apresentam seu terminal carboxila (região C-terminal) com orientação extracelular e o terminal amino (região Nterminal) orientado para o meio intracelular (figura 1A) (Oohashi et al., 1999; Tucker e Chiquet-Ehrismann, 2006). A região C-terminal apresenta oito domínios semelhantes ao fator de crescimento epidermal ("epidermal growth factor-like"- EGF) análogo as tenascinas, seguido por uma região rica em cisteínas e sequências repetidas de aminoácidos tirosina e ácido aspártico (região YD) (figura 1A) (Tucker e Chiquet-Ehrismann, 2006). Esta região apresenta significante identidade tanto em tamanho quanto em estrutura quando comparada às TENs de vertebrados e invertebrados (Oohashi et al., 1999; Tucker e Chiquet-Ehrismann, 2006; Kenzelmann et al., 2008). Além disso, é verificado nesta região carboxi-terminal há 
possibilidade das TENs formarem dímeros logo após serem transportadas para a membrana plasmática através de interações entre o segundo e o quinto domínio semelhante ao EGF (figura 1A) (Lovejoy et al., 2006).

Figura 1 - Análise do modelo estrutural e da organização gênica da TEN 1.
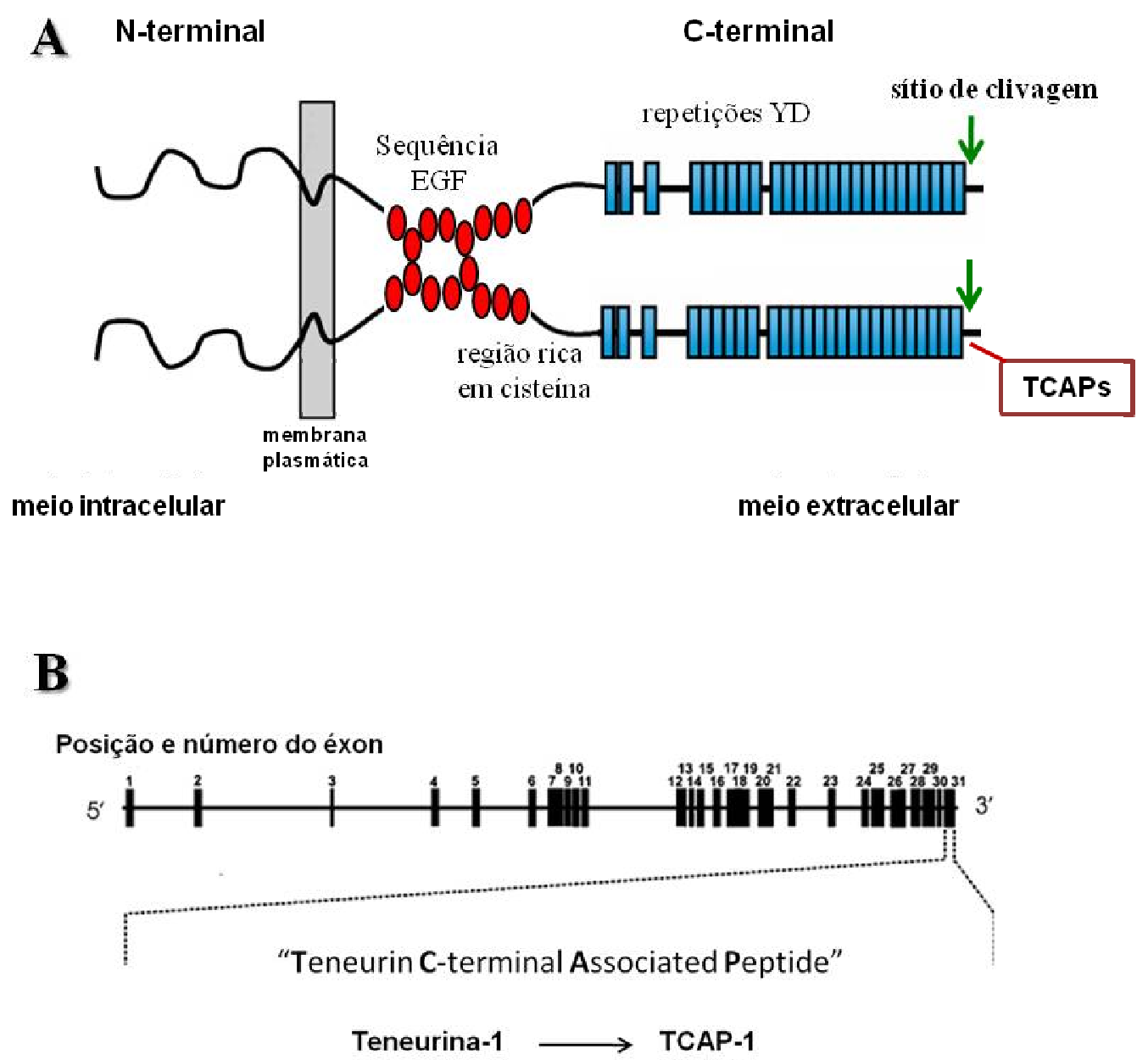

LEGENDA: Em (A) modelo esquemático ilustrando a constituição e a organização dimérica das TENs. A seta mostra o sítio de clivagem localizado na região c-terminal que poderia resultar na liberação dos TCAPs. Em (B) Esquema demonstrando a organização do gene da TEN 1 e a localização da porção gênica do TCAP-1 que poderia ser transcrito independente da TEN1. Esse modelo é similar aos outros membros das TENs e dos TCAPs que possuem localização de sua porção gênica no último éxon de cada TENs.

FONTE: Ilustração extraída e adaptada de Lovejoy et al., 2006.

Estudos pioneiros verificaram que as TENs possuem papel fundamental no desenvolvimento de embriões de Drosophila melanogaster, Mus musculus e Caenorhabditis elegans sendo notado nestes estudos que animais mutantes para TENs apresentam defeitos no desenvolvimento e diferenciação embrionária, principalmente no SNC, que podem resultar na 
letalidade embrionária. Estes dados sugerem que essa família de proteínas possui alguma função indispensável na embriogênese, sem mecanismos compensatórios para minimizar sua ausência (Baumgartner et al., 1994; Levine et al., 1994; Lossie et al., 2005; Drabikowski, Trzebiatowska e Chiquet-Ehrismann, 2005). Outras funções têm sido atribuídas para essa família de proteínas, tais como interação homofílica entre células neuronais (Rubin et al., 2002; Tucker e Chiquet-Ehrismann, 2006; Leamey et al., 2008), orientação axonal (Young e Leamey, 2009), proliferação celular (Kinel-Tahan et al., 2007) e como um cofator na transcrição gênica (Bagutti et al., 2003; Nunes et al., 2005). Essa diversidade funcional é atribuída aos vários domínios de interação molecular, bem como aos sítios de clivagens presentes na porção carboxi-terminal que poderiam liberar peptídeos bioativos (Qian et al., 2004; Kenzelmann et al., 2008).

Devido a interessante participação das TENs no desenvolvimento embrionário, principalmente na neurogênese, estudos verificaram a distribuição da teneurina-1 (TEN 1) no SNC de aves e camundongos. Em embriões de aves, a TEN 1 apresenta padrão de expressão em vias do sistema visual como retina, teto óptico e núcleo rotundo do tálamo e em outras regiões como hipocampo, bulbo olfatório, córtex do cerebelo e tronco encefálico (Rubin et al., 1999; Kenzelmann et al., 2008). Em camundongos adultos, a TEN 1 está presente na retina, córtex cerebral, tálamo, hipocampo, cerebelo (córtex e núcleos cerebelares) e tronco encefálico (Oohashi et al., 1999; Zhou et al., 2003). Estes estudos têm mostrado que as TENs são expressas em vias de processamento sensorial e motor, contudo sem um extensivo detalhamento neuroanatômico.

Um aspecto interessante foi a descoberta que na região c-terminal das TENs há sequências de aminoácidos com identidade com a família de peptídeos do fator liberador da corticotropina (CRF) (Qian et al., 2004; Lovejoy, Rotzinger e Lovejoy-Barsyte, 2009a). Isto foi observado durante o escaneamento da biblioteca genômica de peixe (Oncorhynchus mykiss) com sonda de urocortina-1 de hamster, como intuito de localizar sequências homólogas ao CRF. Além disso, foi constatado que esta sequência c-terminal das TENs podem ser liberadas na forma de peptídeos bioativos devido a existência de potenciais domínios de clivagem. Também é proposto que estes peptídeos possam ser transcritos separadamente a partir do último éxon do gene de cada TENs (figura 1B) (Lovejoy, Rotzinger e Lovejoy-Barsyte, 2009a). Independente da forma de obtenção desses novos peptídeos bioativos, através da clivagem da região c-terminal das proteínas TENs ou transcrição do 
RNAm de parte do gene das TENs (“splice variants”) sugerindo ser um sistema independente das TENs, esses são denominados de TCAPs (Teneurin C-terminal-Associated Peptides). Desta forma, em vertebrados os TCAPs constituem uma família de quatro peptídeos com 40 a 41 aminoácidos, de peso molecular aproximado de $35 \mathrm{kDa}$, com $20 \%$ de identidade estrutural com os peptídeos da família do CRF (tabela 1) e considerados como uma nova família de neuropeptídeos endógenos bioativos (Qian et al., 2004; Wang et al., 2005; Lovejoy, Al Chawaf e Cadinouche, 2006a; Lovejoy, 2009b)

Estudos advindos do grupo de pesquisa do Dr. David A. Lovejoy (Universidade de Toronto, Canadá) reforçam que os TCAPs sejam um sistema independente das TENs (comunicação pessoal) devido: a) os dois últimos éxons do gene da teneurina, que supostamente geram o transcrito do TCAP, apresentam o mesmo tamanho e organização do gene do CRF; b) alguns neurônios em cultura expressam teneurina e não TCAP, através da análise pela reação em cadeia da polimerase via transcriptase reversa (RT-PCR); c) anticorpos policlonais anti-TCAP identificam em "western blotting" uma proteína com 35kDa, aproximadamente do mesmo peso molecular de um transcrito gerado por aqueles éxons; d) os anticorpos anti-TCAP não têm identificado proteínas que corresponderiam ao peso molecular da molécula de teneurina, ou seja, com $300 \mathrm{kDa}$; e) "splice variants" têm sido identificados para o TCAP, enquanto que, até agora "splice variants" não têm sido identificado para as teneurinas; f) a urocortina-2, que pertence a família do CRF e que também apresenta similaridade estrutural com TCAP, tem sido identificado como parte final do gene da glicoproteína colágeno tipo VII $\alpha$ em aves, mas em mamíferos é transcrito por um gene em separado; g) se o TCAP faz parte da proteína teneurina, então a imunorreatividade ao TCAP deveria ser visível na membrana plasmática das células que a expressam, similarmente a imunorreatividade da teneurina, porém sua imunorreatividade não está associada a membrana plasmática; h) estudos em "northen blotting" têm revelado que TCAP-1 e 3 apresentam RNAm com peso molecular correspondente aos dois últimos éxons do RNAm da teneurina.

A análise filogenética entre a família de peptídeos do CRF e dos TCAPs sugere que a família dos TCAPs seja uma linhagem correlata da família de peptídeos do CRF. Ambas as famílias apresentaram um gene ancestral comum que divergiram a partir dos eventos de duplicação genômica, gerando um gene dos TCAPs associado às TENs, e outro gene relacionado com a família de peptídeos do CRF (figura 2) (Lovejoy, Al Chawaf e Cadinouche, 2006a; Lovejoy e Jahan, 2006b; Lovejoy, Rotzinger e Lovejoy-Barsyte, 2009a). 
Tabela 1 - Análise da composição de aminoácidos dos peptídeos das famílias do CRF e dos TCAPs em humanos.

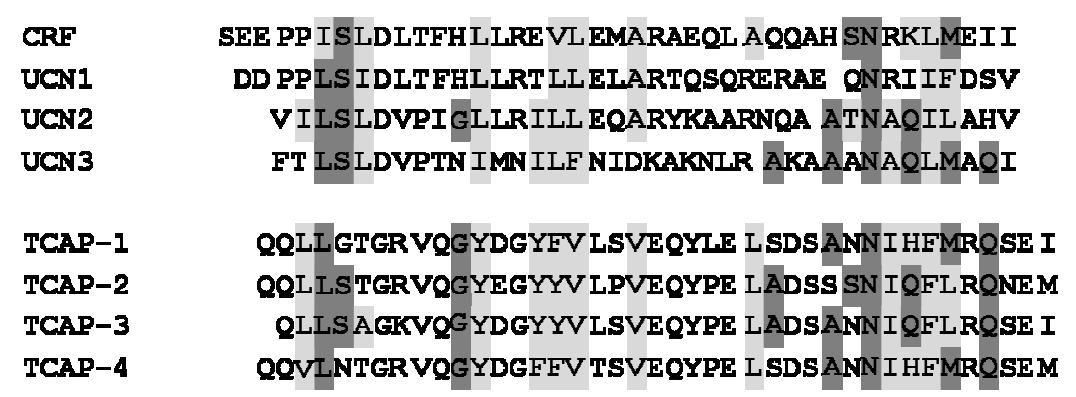

LEGENDA: As caixas em cinza escuro representam os aminoácidos idênticos e as caixas em cinza claro representam os aminoácidos substituídos. Ver lista de símbolos para cada letra que compõe a sequência de aminoácidos.

FONTE: Tabela extraída e adaptada de Wang et al., 2005 e Lovejoy et al., 2006a,b.

Figura 2 - Análise filogenética entre a família de peptídeos do CRF e TCAPs.

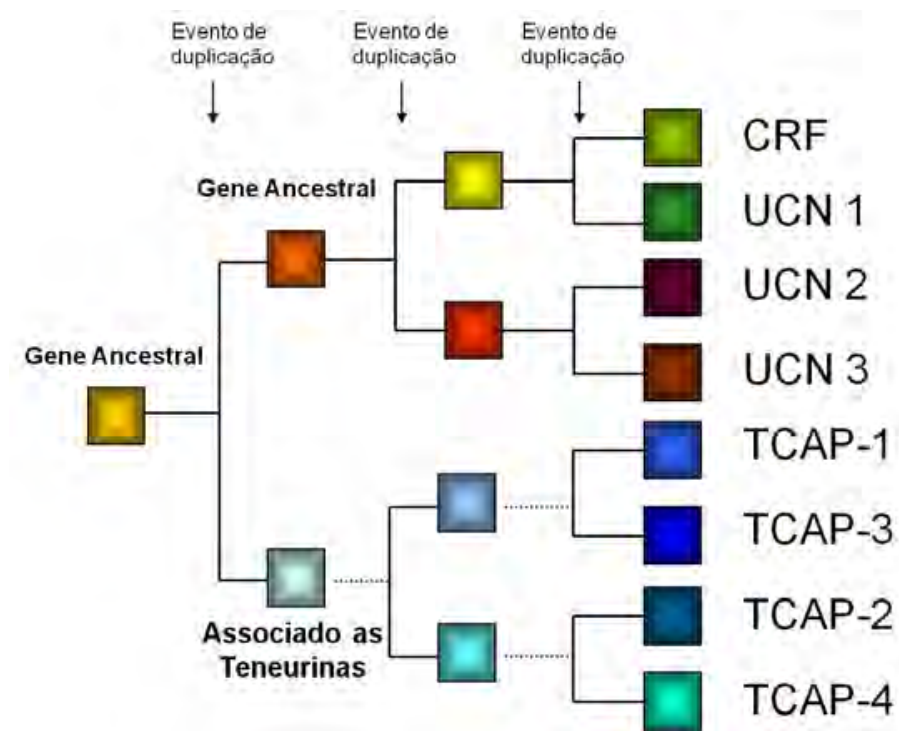

LEGENDA: Nota-se que ao longo da evolução houve um gene ancestral comum a essas duas famílias e que devido a vários processos de duplicação resultou em duas linhagens irmãs codificadas por genes distintos, um para o CRF e um para os TCAPs (associado às teneurinas).

FONTE: Modificado de Tan (2010). Com permissão.

Devido a essas interessantes características descritas para os TCAPs, principalmente no que se refere a sua identidade com a família de peptídeos do CRF, estudos funcionais in vitro e in vivo foram realizados com o propósito de verificar se os TCAPs exercem alguma atividade biológica. A administração in vitro de versões sintéticas de TCAP1 em cultura de células neuronais evidenciaram que esse peptídeo induz a produção de 
adenosina monofosfato cíclico (AMPc) e regula a proliferação e morfologia de neurônios imortalizados (Qian et al., 2004; Wang et al., 2005; Al Chawaf et al., 2007a; Trubiani et al., 2007; Rotzinger, Lovejoy e Tan, 2010). Outros ensaios in vitro revelaram que este peptídeo também atua na sinaptogênese, aumentando a interação tanto em neurônios hipotalâmicos imortalizados como em cultura primária de neurônios hipocampais (Qian et al., 2004; Wang et al., 2005; Al Chawaf et al., 2007a). Este processo possivelmente é mediado através do estímulo do TCAP-1 na transcrição de moléculas chaves do citoesqueleto ( $\beta$-tubulina, $\alpha$ actinina e actina). Estudos também verificaram o papel neuroprotetor do TCAP-1 em situações de estresse celular induzida por mudanças de pH através da indução de superóxido dismutase em cultura de células neuronais (Trubiani et al., 2007).

Estudos in vivo verificaram a capacidade do TCAP-1 em regular estresse comportamental induzido ou não pela administração de CRF (Wang et al., 2005; Al Chawaf et al., 2007b; Tan et al., 2008). A administração intracerebroventricular (i.c.v.) prévia de TCAP-1, seguida da administração i.c.v. de CRF em ratos adultos, revelou um potente papel do TCAP-1 na modulação do comportamento emocional, sugerindo que seus efeitos ansiolíticos ocorrem devido a modulação dos efeitos ansiogênicos induzidos pelo CRF (Arborelius et al., 1999; Tan et al., 2008). Os efeitos resultantes no SNC da administração i.c.v. de TCAP-1 e posteriormente de CRF em ratos adultos foram notados em regiões encefálicas associada ao controle do comportamento emocional. Isto foi constatado devido à redução da expressão de fos ("finkel osteogenic sarcoma"), que é um marcador da atividade neuronal, em regiões límbicas como amígdala e hipocampo quando comparado com animais que receberam somente administração de CRF e apresentaram elevada expressão desse marcador nessas regiões encefálicas (Tan et al., 2009).

Devido aos resultados funcionais obtidos com o TCAP-1, tem sido proposto para um possível emprego terapêutico uma vez que estudos de desordens de humor têm correlacionado o CRF como um dos principais mediadores da resposta ao estresse e, o TCAP1 tem se apresentado como um potente modulador dos efeitos do CRF como verificado nos estudos in vivo (Arborelius et al., 1999; Wasserman, Wasserman e Sokolowski, 2010). Os efeitos ansiogênicos do CRF são bem descritos em estudos experimentais feitos em ratos, os quais apresentam diminuição do apetite, aumento da frequência cardíaca e da pressão sanguínea e maior incidência de comportamentos associados à ansiedade após receberem administração intracerebral de CRF (Rothwell, 1990; Buwalda et al., 1997). Deste modo, o 
TCAP-1 além de compartilhar identidade estrutural com peptídeos da família do CRF, possivelmente apresenta propriedades fisiológicas antagônicas sendo considerado um modulador promissor para atenuar as ações do CRF principalmente no que se refere ao controle comportamental associado à ansiedade (Lovejoy, Al Chawaf e Cadinouche, 2006a; Lovejoy e Jahan, 2006b; Al Chawaf et al., 2007b; Kupferschmidt et al., 2011).

Com relação ao mecanismo de ação do TCAP-1, este ainda é incerto, pois, embora apresente similaridade com os peptídeos da família do CRF há possibilidade de apresentar um receptor distinto dessa família. Essa hipótese foi confirmada por estudos que verificaram que o TCAP-1 alterou as concentrações de AMPc em neurônios que não expressavam receptores de CRF, ou quando era aplicado antagonista específico para receptores de CRF em neurônios responsivos ao CRF (Wang et al., 2005). Estudos sugerem que como o TCAP-1 é capaz de ocasionar mudanças em componentes do citoesqueleto (Al Chawaf et al., 2007a) isso resultaria na alteração estrutural das células neuronais e assim redução da ativação dos receptores do CRF e inibição dos efeitos desse neuropeptídeo a nível celular e comportamental (Kupferschmidt et al., 2011).

Apesar dos estudos para o TCAP-1 apresentarem interessantes papéis funcionais, nota-se que há uma carência de estudos de distribuição neuroanatômica do TCAP-1 que poderiam justificar seus efeitos funcionais assim como a possível aplicação terapêutica em humanos. Até o momento a distribuição neuroanatômica de TCAP-1 foi somente descrita em ratos adultos por Wang et al. (2005). Neste estudo foi verificado que a expressão do RNAm de TCAP-1 no SNC encontra-se em regiões associadas com comportamento emocional, aprendizado, ansiedade e mecanismos de compensação sendo muita destas regiões distintas daquelas que expressam TEN 1 (Wang et al., 2005). Os resultados de distribuição de TCAP-1 no hipocampo de rato, previamente descrito por Wang, et al. (2005), estão sendo confirmados por Chand, 2011 (em fase de elaboração) ${ }^{1}$ que ainda relata que a distribuição desse peptídeo mostra-se difusa no SNC porém, particularmente pronunciada no sistema límbico e em regiões do córtex pré-frontal.

\footnotetext{
${ }^{1}$ Chand D, Al Chawaf A, Tan LA, Ng T, Casatti C, Song L, Kollara A, Brown T, Rotzinger S, Belsham DD, Boutros P, Vaccarino FJ, Barsyte-Lovejoy D, Lovejoy DA. C-terminal region of teneurin-1 in mouse hippocampus: Cellular and tissue locations, binding site and regulation of dendritic arborization. Journal of Neuroscience.
} 
O estudo da distribuição neuroanatômica do TCAP-1 no encéfalo de primata nãohumano (Cebus apella) visa: suprir a ausência de um mapeamento detalhado deste sistema peptidérgico no SNC e verificar se o mesmo encontra-se preservado ao longo das espécies. Consideramos que os resultados obtidos neste estudo podem fornecer maiores subsídios neuroanatômicos ao possível emprego terapêutico proposto para o TCAP-1 no tratamento de desordens de humor como depressão e ansiedade. Vale ser ressaltado que esta análise se restringiu a apenas um dos membros da família dos TCAPs, uma vez que a maior parte dos dados funcionais advém do TCAP-1. Além disso, será verificado se há correspondência de distribuição da TEN 1 e TCAP-1 em algumas regiões encefálicas para confirmar se ambos os sistemas se encontram em regiões encefálicas distintas como descrito na literatura. 


\subsection{Geral}

Mapear a distribuição dos neurônios imunorreativos e que expressam o RNAm para o TCAP-1 no SNC de Cebus apella.

\subsection{Específico}

Analisar a distribuição do peptídeo TCAP-1 no encéfalo do primata não-humano (Cebus apella) por meio da técnica de imuno-histoquímica (método imunoperoxidase indireta) e hibridização in situ (com sonda marcada $\operatorname{com}^{35} \mathrm{~S}$ ). Verificar, em algumas regiões encefálicas Cebus apella, se há correspondência de distribuição de corpos neuronais imunorreativos para TEN 1 e TCAP-1em uma mesma espécie por meio da técnica de imunohistoquímica (método imunoperoxidase e dupla imunofluorescência). 


\subsection{Cebus apella}

Os primatas não-humanos do gênero Cebus apella, conhecidos popularmente como macacos-prego, são classificados como primatas do Novo Mundo embora apresentem certa similaridade com alguns primatas do Velho Mundo sendo muitas vezes comparados com a Macaca fascicularis e Macaca mulatta (conhecido como macaco-rhesus).

O macaco Cebus apella possui hábitos diurnos, porte médio (aproximadamente 60 cm de comprimento) com constituição robusta e cauda preênsil que lhes confere agilidade para correr e saltar entre as árvores em busca de alimentos. A alimentação é variada sendo composta por folhas, sementes, frutos, ovos, insetos e eventualmente filhotes de aves. Possuem elevada sociabilidade sendo frequientemente vistos em grandes grupos e mantendo hábitos familiares. A maturidade sexual pode ser estimada pelo estágio de erupção dos dentes caninos e pelo peso aproximado de $2,5 \mathrm{~kg}$ para machos e de 1,8 $\mathrm{kg}$ para as fêmeas (Nagle e Denari, 1982) sendo constatado que a vida média desses animais está por volta dos 45 anos. A reprodução dessa espécie ocorre uma vez ao ano, com uma única cria, cujo período de gestação é de cerca de seis meses. Essa espécie é habitante típico de matas do continente sulamericano estando distribuído por quase todo o Brasil além do leste da Colômbia, Peru e Bolívia (Hill, 1960).

Apresentam elevada destreza manual sendo conhecidos como um dos macacos mais inteligentes do Novo Mundo. Estes animais frequentemente utilizam ferramentas da natureza com tamanha habilidade que até então só era verificada em hominóides. As ferramentas mais comuns são as pedras utilizadas para quebra de frutos encapsulados (cocos) e para cavar o solo em busca de raízes comestíveis. Também utilizam varetas para capturar larvas de insetos e mel de ocos de árvores.

A anatomia macroscópica do encéfalo do Cebus apella revela organização geral semelhante à de outras espécies de primata incluindo principalmente a espécie humana. Entretanto, estudos comparativos entre as espécies têm verificado peculiaridades em algumas estruturas do SNC, sendo isso considerado como um indicador de evolução e adaptação (Crosby, Humphrey e Lauer, 1962).

Em conjunto com a análise macroscópica do encéfalo desse primata não-humano, na qual tem sido verificada grande semelhança neuroanatômica com o encéfalo humano, a análise comportamental também tem mostrado semelhanças entre primatas não-humanos e 
humanos atraindo dessa forma grande interesse em pesquisas para avaliar as semelhanças e diferenças ao longo da evolução. O uso crescente desses animais em pesquisa também se deve ao pequeno porte, boa adaptação em cativeiro, e fácil manuseio (Carvalho-Barros, 2002).

Desta forma, para a realização deste projeto de pesquisa foram utilizados macacos machos adultos jovens da espécie Cebus apella $(\mathrm{n}=3$ ), em condições normais (sem indução de qualquer estímulo estressor ou de dependência), com peso de aproximadamente $2.200 \mathrm{a}$ 2.700 g, que pertenciam ao Núcleo de Procriação de macacos-prego associado ao Departamento de Ciências Básicas da Faculdade de Odontologia de Araçatuba - UNESP. O fornecimento e o uso para pesquisa desses animais foram fiscalizados e orientados segundo normas e procedimentos do próprio Núcleo de Procriação de Macacos-prego, da portaria 016/94 do Instituto Brasileiro do Meio Ambiente (IBAMA) de 04 de abril de 1995 e do Comitê de Ética em Experimentação Animal do Instituto de Ciências Biomédicas-USP/SP.

\subsection{Perfusão transcardíaca}

A fixação histológica transcardíaca é um método preconizado devido à alta capacidade de fixação e preservação dos tecidos, principalmente no que se refere ao SNC. Os procedimentos de fixação e preparo histológico do tecido nervoso seguiram os protocolos estabelecidos para o SNC de macacos (Rosene, Roy e Davis, 1986; St John, Rosene e Luebke, 1997). Inicialmente, os animais foram tranquilizados com injeção intramuscular de cloridrato de cetamina (10 mg/kg de peso corporal) e logo após anestesiados com injeção intraperitoneal de tiopental sódico (30mg/kg de peso corporal, Thionembutal ${ }^{\circledR}$ - Fontoveter, Brasil) e injeção intramuscular de benzodiazepínico $\left(0,3 \mathrm{mg} / \mathrm{kg}\right.$ de peso corporal, Diazepan ${ }^{\circledR}$ - União Química Farmácia Nacional S.A., Brasil). Em seguida, iniciaram-se os procedimentos de perfusão transcardíaca através da exposição da cavidade torácica por meio de um corte sagital mediano que se estendeu da região do manúbrio do esterno até o nível da sínfise púbica. Em seguida as costelas foram rebatidas expondo assim os átrios e ventrículos cardíacos e a injeção de $1 \mathrm{ml}$ de anticoagulante (Heparina sódica, 5000UI- Sigma Chemical, St. Louis, MO, USA) foi feita intraventricular para evitar a coagulação e posterior obstrução dos vasos sanguíneos que impediria o sucesso da perfusão transcardíaca. O ventrículo esquerdo foi seccionado e puncionado até a aorta ascendente com uma cânula acoplada a um sistema de perfusão com bomba peristáltica (Masterflex® LS). Em prosseguimento, o átrio direito foi seccionado para 
que todas as soluções infusionadas fossem drenadas. Inicialmente foi perfundido, na velocidade de $80 \mathrm{ml} / \mathrm{min}, 500 \mathrm{ml}$ de solução salina $(0,9 \%)$, seguido de 2 litros de solução fixadora de formaldeído a $4 \%$ em tampão acetato $0,1 \mathrm{M}(\mathrm{pH}$ 6.5) importante para a difusão do formaldeído no tecido e, finalmente com 2 litros de solução fixadora de formaldeído a $4 \%$ em tampão tetraborato de sódio $0,1 \mathrm{M}(\mathrm{pH}$ 9.5) que permite maior interação das moléculas do formaldeído com os constituintes do tecido. Ressaltamos que todas as soluções empregadas na perfusão transcardíaca foram mantidas em refrigerador até o momento da utilização. Ao final deste procedimento o animal estava totalmente enrijecido, confirmando o sucesso da perfusão transcardíaca com soluções fixadoras histológicas. Vale ser ressaltado que todos os animais utilizados foram submetidos ao procedimento de perfusão transcardíaca no período da manhã (entre 09h00min as 12h00min horas).

Após a perfusão o crânio foi fixado em aparelho estereotáxico (David Kopf, Alemanha) e o neuroeixo foi cuidadosamente dissecado e seccionado em blocos de cortes frontais em níveis estereotáxicos pré-estabelecidos. Após, os blocos encefálicos foram lavados rapidamente em solução fisiológica estéril e crioprotegido em solução de $10 \%$ de glicerol (Labsynth produtos para laboratórios Ltda, Brasil) e 2\% de dimetilsulfóxido (DMSO) em tampão tetraborato de sódio $0,1 \mathrm{M}$ (pH 9.5) em água tratada com DEPC (dietilpiracarbonato, necessário para manter o tecido "RNAse free") por 3 dias a $4^{\circ} \mathrm{C}$. Decorrido o tempo anteriormente citado, os blocos encefálicos foram transferidos para uma segunda solução crioprotetora constituída de $20 \%$ glicerol (Labsynth Ltda, Brasil) e $2 \%$ de DMSO em tampão tetraborato de sódio $0,1 \mathrm{M}(\mathrm{pH} 9.5)$ a $4^{\circ} \mathrm{C}$. O tempo de permanência nessa solução foi de 7 a 10 dias até a realização da microtomia.

Durante todo os procedimentos houve precauções e cuidados, como a utilização de luvas e soluções tratadas com DEPC, para evitar contaminação por enzimas ribonucleases (RNases) que interferem na preservação do RNAm e, consequentemente, no sucesso da técnica de hibridização in situ (HIS).

\subsection{Microtomia}

Para a realização da microtomia os blocos encefálicos foram removidos da solução de crioproteção e acondicionados em base metálica $(18,7 \mathrm{~cm}$ x 8,3 cm) adaptada para uso em micrótomo de congelamento (SM 2000R, Leica®, Alemanha). As secções foram 
realizadas em plano frontal com obtenção de cortes de $40 \mu \mathrm{m}$ de espessura. Os cortes foram armazenados em caixas contendo 8 séries, sendo que cada série é constituída de 6 poços. $\mathrm{O}$ armazenamento dos cortes foi feito a $-20{ }^{\circ} \mathrm{C}$ em solução tamponada de anticongelante "RNase-free" constituída de 0,5x PBS, 30\% etilenoglicol (Labsynth produtos para laboratórios Ltda, Brasil) e 20\% glicerol (Synth, SP, Brasil).

Após a microtomia e armazenamento dos cortes histológicos, foi selecionado algumas séries de cortes de cada animal para a técnica de HIS, imuno-histoquímica e coloração histoquímica pela técnica de Nissl de forma a obter cortes representativos de toda a extensão rostro-caudal do neuroeixo. Todos os procedimentos de microtomia, armazenamento, seleção e montagem dos cortes histológicos foram realizados sob os mesmos cuidados "RNase-free" descritos acima, com cuidado adicional de manipulação dos cortes histológicos com pincéis livres de RNases. Para isso precedeu-se a uma lavagem inicial dos pincéis utilizados em $\mathrm{H}_{2} \mathrm{O}-\mathrm{DEPC}$ não autoclavada (15 min) e manutenção desses em solução tamponada de formalina a $10 \%$ para inativação de possíveis RNases.

\subsection{Hibridização in situ}

A hibridização in situ (HIS) é uma técnica da biologia molecular de alta especificidade e que permite identificação e localização de um gene de interesse ou de seu transcrito in locus em um dado tecido. Neste trabalho foi utilizada a técnica de HIS com sonda de RNA complementar (cRNA), específica para TCAP-1e para a espécie Cebus apella, marcadas com radioativo $\left({ }^{35} \mathrm{~S}\right)$. Estas sondas ligam-se as fitas de RNAm do TCAP-1 presente no tecido nervoso permitindo posteriormente a visualização, em microscopia de luz, das regiões encefálicas que expressam o RNAm para TCAP-1. As etapas para a realização dessa técnica foi desenvolvida no Laboratório de Neuroanatomia Química sob co-orientação do Prof. Dr. Jackson C. Bittencourt (Departamento de Anatomia, ICB-USP).

\subsubsection{Análise das sequências do TCAP-1 do Cebus apella}

Previamente a confecção da sonda a ser usada na técnica de HIS tivemos o cuidado em avaliar se a sequiência espécie-específica por nós desenhada seria capaz de transcrever a sequiência de TCAP-1 do Cebus apella. Para isso os plasmídeos que 
apresentavam o inserto de DNA do Cebus apella para a seqüência do TCAP-1 foram encaminhados para seqüenciamento comercial (ATCG Corp., Toronto, ON). As sequências encaminhadas pela empresa foram analisadas e traduzidas usando programa de acesso público Expasy (URL: http://expasy.org/). A análise da identidade entre os aminoácidos que compõe o TCAP-1 do Cebus apella e de outras espécies foi verificada empregando-se software Blast (URL: http://web.expasy.org/blast/) e após, os mapas dos plasmídeos foram desenhados. Para manutenção do plasmídeo com o inserto de DNA foi realizado a transfecção química em bactérias Escherichia coli (E. Coli) (OneShot@ Chemically Competent E. Coli, Invitrogen) e armazenamento destas a $-80^{\circ} \mathrm{C}$.

\subsubsection{Isolamento e purificação de plasmídeos}

Após a estocagem das bactérias transfectadas estas foram multiplicadas em 500 $\mathrm{ml}$ do meio de cultura LB (Luria Broth ) com ampicilina a $37^{\circ} \mathrm{C}$ "overnight" em agitador orbital a $225 \mathrm{rpm}$ e posterior purificação dos plasmídeos empregando-se kits comerciais QIAprep Spin Miniprep kit (27104, Qiagen). Esses kits empregam o método da lise bacteriana por meio de várias soluções tampão, adsorção do plasmídeo em membranas de sílica disposta em colunas, lavagem e eluição do plasmídeo.

Inicialmente foi realizado o equilíbrio das colunas pela adição de $10 \mathrm{ml}$ do tampão de equilíbrio (Teq). Após, 1,5 $\mathrm{ml}$ das bactérias transformadas e multiplicadas no meio de cultura LB foram transferidas para tubos estéreis de $2 \mathrm{ml}$, enquanto o restante da solução bacteriana foi estocada a $-80{ }^{\circ} \mathrm{C}$. As bactérias transformadas foram centrifugadas a 5000rpm por 15 minutos a $4{ }^{\circ} \mathrm{C}$. O sobrenadante formado foi descartado e as bactérias transformadas foram ressuspendidas com adição de $10 \mathrm{ml}$ de tampão de suspensão celular (Tsusp) até a solução se tornar homogênea. Foram adicionados $10 \mathrm{ml}$ do tampão de lise (Tlise) e misturado delicadamente por inversão e após incubado a temperatura ambiente por 5 minutos. Em seguida, adicionou-se $10 \mathrm{ml}$ do tampão de neutralização (Tneutr) e misturou-se por inversão (5 vezes). As células já lisadas foram então centrifugadas a $11000 \mathrm{rpm}$ por 10 minutos a $4{ }^{\circ} \mathrm{C} \mathrm{e}$ posteriormente passada nas colunas previamente equilibradas para separação do plasmídeo dos restos celulares. A coluna foi então lavada com $30 \mathrm{ml}$ de tampão de lavagem (Tlav) e o eluato foi descartado. Após foi adicionado tampão de eluição (Telu) e 10,5ml de isopropanol ao eluato seguido de centrifugação a $11000 \mathrm{rpm}$ por 30 minutos a $4{ }^{\circ} \mathrm{C}$. O pellet formado, que 
contém somente os plasmídeos com o inserto, foi lavado com $5 \mathrm{ml}$ de álcool $70 \%$, centrifugado a $9000 \mathrm{rpm}$ por 10 minutos a $4{ }^{\circ} \mathrm{C}$ e seco a temperatura ambiente. Após o pellet foi ressuspendido com tampão Tris-EDTA para verificar a integridade e a quantidade do DNA em eletroforese em gel de agarose e espectrofotômetro, respectivamente. O comprimento de onda utilizado no espectrofotômetro foi de $280 \mathrm{~nm}$, sendo que 1 representa $50 \mu \mathrm{g}$ de DNA/ml. Após as soluções de plasmídeos foram estocadas a $-20{ }^{\circ} \mathrm{C}$. Para a realização da eletroforese em gel de agarose foi realizado as seguintes etapas: a) preparo do gel de agarose $(0,5 \%)$ em um béquer, acrescentando $50 \mathrm{ml}$ de 1 xTAE e $0,25 \mathrm{~g}$ de agarose, após essa mistura foi agitada e aquecida até dissolver por completo (aproximadamente 40 segundos em microondas); b) acrescentou-se a mistura $1 \mu \mathrm{l}$ de brometo de etídio; c) o gel foi colocado no aparelho de eletroforese junto com o pente de larga quantidade até que ocorresse o endurecimento ( após 20 minutos); d) após o gel adquirir consistência o pente foi removido delicadamente e em seguida o gel de agarose foi coberto $200 \mathrm{ml}$ de 1xTAE; e) as amostras de DNA foram preparados com $4 \mu 1$ de $\mathrm{H}_{2} \mathrm{O}$ estéril, $1 \mu \mathrm{l}$ do DNA circular (inserto + plasmídeo) e $1 \mu \mathrm{l}$ do blue juice (corante) (Invitrogen, Califórnia, USA) sendo depositadas na cavidade do gel de agarose; f) em seguida aplicou-se corrente de 60 a $80 \mathrm{mV}$ por 30 minutos e a integridade dos plasmídeos com o inserto foi avaliado no gel de agarose através de uma câmara de análise de imagens iluminada com luz ultravioleta (Epi-chemi II-Darkroom, UVP Laboratory Products) acoplada com câmara CCD, cuja imagem obtida foi transferida para um computador com o software Labworks (Labworks Image Acquisition and Analysis software, UVP Bioimaging Systems) e gravadas como arquivos de imagem.

\subsubsection{Linearização do plasmídeo e transcrição in vitro}

Para a confecção da sonda o plasmídeo com inserto foi inicialmente linearizado, utilizando enzimas de restrições adequadas para não clivar o inserto, e em seguida adicionado polimerases para a síntese da sonda. Em nossas amostras utilizou-se a enzima de restrição Apa I seguindo as seguintes etapas para a linearização de $20 \mu \mathrm{g}$ do DNA plasmidial: a) $5 \mu \mathrm{l}$ de 10x tampão (específico para a enzima utilizada) adicionado em um tubo Eppendorf estéril com capacidade para $1,5 \mathrm{ml}$; b) adição de $20 \mu \mathrm{g}$ de DNA plasmidial; c) adição da enzima de

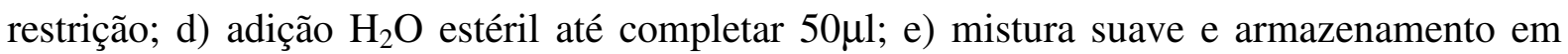
tubo Eppendorf em banho-maria a $37{ }^{\circ} \mathrm{C}$ “overnight”. Para fazer o isolamento (limpeza) do 
template após a linearização realizou-se: f) elevação do conteúdo do tubo de Eppendorf para $100 \mu 1$ com $\mathrm{H}_{2} \mathrm{O}$ estéril e mistura por inversão; g) adição de $100 \mu 1$ de fenol-clorofórmio-álcool isoamílico e mistura da solução em vórtex por 1 min e à centrífuga por 3 min a $4^{\circ} \mathrm{C}$ em velocidade de $5000 \mathrm{rpm}$; h) remoção cuidadosa do sobrenadante e transferência para outro tubo estéril; i) adição $10 \mu \mathrm{l}$ de acetato de sódio $3 \mathrm{M}$ e $200 \mu \mathrm{l}$ de álcool etílico absoluto (armazenado a $-20^{\circ} \mathrm{C}$ ), mistura por inversão; j) remoção do líquido formado, tomando-se cuidado para não desprezar o pellet; 1) lavagem do pellet com $200 \mu 1$ de álcool etílico $70 \%$ e centrifugação por 5 min a $4{ }^{\circ} \mathrm{C}$ em velocidade de $15000 \mathrm{rpm}$; m) remoção do líquido e secagem do pellet em temperatura ambiente (30 a 60 min); n) adição de $20 \mu 1$ de $\mathrm{H}_{2} \mathrm{O}$ estéril, homogeneização e armazenamento a $-20^{\circ} \mathrm{C}$. A quantidade de DNA foi estimada por meio de espectrofotômetro e a linearização e a integridade do DNA foram avaliadas por eletroforese em gel de agarose, protocolo já descrito acima.

A transcrição in vitro das sondas anti-sense de cRNA foi realizada em um tubo de Eppendorf de 1,5 ml, em banho-maria a $40{ }^{\circ} \mathrm{C}$ por $1 \mathrm{~h} 30 \mathrm{~min}$, contendo: $1 \mathrm{x}$ tampão de transcrição; 10 mM DTT; $1 \mathrm{u} / \mu \mathrm{L}$ Rnasin; $500 \mu \mathrm{M} \Delta \mathrm{NTP} ; 0,05 \mu \mathrm{g} / \mu \mathrm{l}$ de cDNA linearizado; $100 \mu \mathrm{Ci} \mathrm{UTP}{ }^{35} \mathrm{~S} ; 0,75 \mathrm{u} / \mu \mathrm{L}$ RNA polimerase (SP6). Após esse período, adicionou-se mais $1 \mu \mathrm{l}$ da RNA polimerase e incubação a $37^{\circ} \mathrm{C}$ por mais $30 \mathrm{~min} . \mathrm{O}$ volume da solução foi então elevado para $50 \mu \mathrm{L}$ com $\mathrm{H}_{2} \mathrm{O}$ estéril seguindo a seguinte etapa de purificação da sonda com adição de $1 \mu \mathrm{L}$ de inibidor de Rnase (Rnasin) e $1 \mu \mathrm{L}$ de desoxirribonuclease (DNase) para clivar o cDNA (template), por 10 min a $37{ }^{\circ} \mathrm{C}$. Os nucleotídeos não incorporados e os derivados da clivagem do cDNA foram removidos através de microcolunas de resina, respeitando a orientação do laboratório de acordo com os seguintes passos: a) resuspensão da coluna de resina por meio de agitação em vórtex por 5 segundos; b) quebra da parte inferior da coluna e abertura parcial da tampa (meio giro); c) a coluna foi colocada em um tubo Eppendorf vazio e estéril de $1,5 \mathrm{ml}$ e centrifugado a $4{ }^{\circ} \mathrm{C}$ em velocidade de $3500 \mathrm{rpm}$ por 2 min; d) após a coluna foi colocada em um novo Eppendorf e aplicado a sonda no centro da coluna; d) centrifugação a $4{ }^{\circ} \mathrm{C}$ em velocidade de $3500 \mathrm{rpm}$ por $2 \mathrm{~min}$; e) transferência da sonda para um tubo com tampa de rosca; f) adição de $1 \mu \mathrm{L}$ de $5 \mathrm{M}$ ditiotreitol (DTT) e contagem da incorporação do radioisótopo em aparelho de cintilação (contador $\beta$ ). Para isso adicionou-se $1 \mu \mathrm{L}$ da sonda marcada em $4 \mathrm{ml}$ de líquido de cintilação. O cálculo da quantidade de sonda necessária para a hibridização se baseou na incorporação do 
radioisótopo, com utilização da sonda na concentração aproximada de $10^{6} \mathrm{cpm} / \mathrm{ml}$. Vale ser ressaltado que durante a transcrição das sondas as mesmas foram associadas a moléculas radioativas (radioisótopo ${ }^{35} \mathrm{~S}$ ) para permitir posterior visualização das áreas hibridizadas. Esse radioisótopo mostra-se eficiente quando comparado a outros radioisótopos devido à resolução celular, estabilidade da sonda e segurança. Devido sua baixa capacidade de propagação é efetivamente bloqueada com uso de jalecos e luvas e sua detecção pode ser registrada com o uso de um contador Geiger que auxilia no monitoramento das áreas caso estas sejam contaminadas com o radioativo. Todos os procedimentos e equipamentos laboratoriais seguem as normas para a utilização de material radioativo e estão autorizados pela Comissão Nacional de Energia Nuclear (CNEN).

\subsubsection{Pré-tratamento (desproteinização e neutralização dos tecidos)}

Previamente a aplicação das sondas transcritas sobre o tecido nervoso é necessário o preparo deste tecido a fim de eliminar proteínas que estejam associadas ao RNA através do ataque enzimático proteolítico (desproteinização) e ataques ácidos (neutralização) para permitir melhor penetração das sondas. Desta maneira após a microtomia do neuroeixo os cortes destinados à técnica de HIS foram montados em lâminas de vidro carregadas eletricamente (Brain Research Laboratories ${ }^{\circledR}$ microscope slides 50x75x1.0mm adhesion superfrost plus) e secas a temperatura ambiente durante 12 horas. Posteriormente, o armazenamento das mesmas foi feito em caixas com cápsulas de sílica e mantidas a $-20^{\circ} \mathrm{C}$ até a realização do pré-tratamento para a HIS. Para o pré-tratamento foi utilizado a enzima proteolítica proteinase $\mathrm{K}$ e o processo de acetilação para a neutralização do tecido de acordo com as seguintes etapas: a) acondicionamento das lâminas em racks histológicos; b) incubação das lâminas em solução de formaldeído $4 \%$ em 1x PBS por 5 min; c) duas lavagens em 1x PBS (sendo que a primeira lavagem foi rápida para retirar o excesso da solução empregada anteriormente e a segunda lavagem feita por $10 \mathrm{~min}$ ); d) incubação em solução de $0,5 \mu \mathrm{g} / \mathrm{ml}$ de proteinase $\mathrm{K}$ por 30 min à temperatura ambiente de $37^{\circ} \mathrm{C}$; e) lavagem das lâminas em $\mathrm{H}_{2} \mathrm{O}$-DEPC; f) lavagem das lâminas com trietanolamina-ácido clorídrico (TEA-HCL) 0,1M por 10 min; g) Incubação das lâminas em TEA-HCL + anidrido acético em temperatura ambiente, por $10 \mathrm{~min}$; h) lavagem das lâminas em 2x tampão citrato de sódio (SSC). Após estas etapas o tecido foi desidratado em álcool etílico (álcool 70\% - 1 min; 
álcool 80\% - 1 min; álcool 95\% - 2 min; álcool 100\% - 1 min); deslipidificado em xilol (xilol - 15 min) e reidratado brevemente em álcool (álcool 100\% - 1 min; álcool 95\% - 1 min). Após a secagem das lâminas em temperatura ambiente foi feita a hibridização.

\subsubsection{Hibridização e pós-hibridização}

Após o pré-tratamento do tecido e confecção das sondas foi realizado a HIS. Esta etapa compreende na adição das sondas que foram transcritas em um tampão de hibridização (TH) e então aplicação destas às lâminas histológicas pré-tratadas. Para tanto, inicialmente as lâminas foram acondicionadas em uma bandeja forrada com papel filtro umidificada com solução tampão $4 \mathrm{x}$ de citrato de sódio (4 x SSC) e $50 \%$ de formamida. Seguiram-se as seguintes etapas: a) em um tubo contendo $750 \mu \mathrm{L}$ de $2 \mathrm{x}$ de $\mathrm{TH}$, adicionou-se a sonda marcada com ${ }^{35} \mathrm{~S}$ e deixou em banho-maria por 5 min a $90{ }^{\circ} \mathrm{C}$ e depois em gelo por $5 \mathrm{~min}$; b) acrescentou-se $750 \mu \mathrm{L}$ de formamida, homogeneizando bem; c) acrescentou-se $15 \mu \mathrm{L}$ de lauril sulfato de sódio a $10 \%, 15 \mu \mathrm{L}$ de tiossulfato de sódio a $10 \%, 30 \mu \mathrm{L}$ de $5 \mathrm{M}$ DTT e misturou-se por inversão. Seguiu a aplicação dessa solução (aproximadamente $200 \mu \mathrm{L}$ ) no tecido sendo posteriormente protegido com lamínula plástica estéril e incubado "overnight" em estufa à $57^{\circ} \mathrm{C}$. Para a manutenção de um meio úmido no interior da estufa foi colocado placas de petri com água para assim evitar o ressecamento do tecido que poderia prejudicar o processo de hibridização.

Na etapa de pós-hibridização, as lamínulas plásticas foram retiradas e procederam-se os banhos de estringência, para diminuir hibridizações inespecíficas, seguidos de desidratação do tecido de acordo com os seguintes passos: a) remoção das lamínulas plásticas mergulhando-as em solução de 2x SSC e acomodação das lâminas em racks com 2x SSC; b) adicionou-se a $250 \mathrm{ml}$ do tampão de RNAse $20 \mu \mathrm{g} / \mathrm{ml}$ de RNase A seguida da adição dessa solução nas cubetas com o rack contendo as lâminas; c) secagem em temperatura ambiente por $30 \mathrm{~min}$; d) lavagem em tampão de RNAse por 30 min em temperatura ambiente; e) transferência do tecido para um rack contendo 2x SSC seguindo os banhos de estringência; f) lavagem por 1 hora em $2 \mathrm{x} \mathrm{SSC} \mathrm{a} 50^{\circ} \mathrm{C}(+50 \mu \mathrm{l}$ de $5 \mathrm{M}$ DTT); g) alguns mergulhos em 0,2x $\mathrm{SSC}$ a $55^{\circ} \mathrm{C}(+50 \mu \mathrm{l}$ de $5 \mathrm{M} \mathrm{DTT})$; h) lavagem por 1 hora em $0,2 \mathrm{x}$ SSC a $55^{\circ} \mathrm{C}(+50 \mu \mathrm{l}$ de $5 \mathrm{M}$ DTT); i) lavagem por 1 hora em 0,2x SSC a $60^{\circ} \mathrm{C}(+50 \mu l$ de $5 \mathrm{M}$ DTT). A adição do DTT aos banhos de estrigências tem por finalidade auxiliar na estabilização do ${ }^{35} \mathrm{~S}$ utilizado; j) 
desidratação em álcool etílico 70\% acrescido de $0,25 \mathrm{ml}$ de 20x SSC e 50 $\mu 1$ de DTT por 10 min. Após as lâminas foram secas ao ar livre e posteriormente detectou-se o sinal da sondas em filme radiográfico durante exposição de aproximadamente quatro dias.

Após a detecção do sinal de hibridização em filme radiográfico, as lâminas foram mergulhadas individualmente em emulsão radiográfica, armazenadas em caixas histológicas e mantidas em câmera fria por aproximadamente 30 dias. Posteriormente as lâminas foram reveladas e fixadas para garantir a visualização em microscopia de luz dos grânulos de prata nas regiões hibridizadas. Todos esses procedimentos foram realizados em câmera escura, tendo cuidado adicional de proteger a caixa histológica da luminosidade. Após a revelação e fixação das lâminas, estas foram lavadas em água corrente por 15 minutos e em seguida submetidas a contra-coloração através da histoquímica pela técnica de Nissl com tionina a 0,25\%. Após a passagem das lâminas neste corante realizou-se 10 banhos em água destilada e desidratação em álcool 50\% e álcool 70\% (apenas banho das lâminas); álcool 95\% por 2 minutos; álcool $100 \%$ por 2 minutos. A deslipidificação foi realizada em xilol por aproximadamente 6 minutos e após iniciou-se a cobertura das lâminas com DPX (Sigma Chemical, St. Louis, MO, USA) e lamínulas de vidro.

\subsection{Coloração pela técnica de Nissl (tionina $0,25 \%$ )}

Para referência citoarquitetônica dos grupamentos neuronais que apresentam tanto sinal da HIS ou imunorreatividade para TCAP-1 foi submetido uma série de cortes histológicos do SNC ao método de coloração de Nissl. Esse método consiste na utilização de um corante básico que possui afinidade aos ácidos ribonucléicos (RNA) que estão abundantes no citoplasma dos neurônios. Para esta técnica utilizamos as seguintes etapas: a) banhos de desidratação das lâminas com os cortes histológicos em álcool 95\% por 6 minutos, álcool $100 \%$ por 9 minutos e deslipidificação em xilol por 40 minutos; b) reidratação com banhos de 6 minutos em álcool 100\%, 6 minutos em álcool 95\%, 3 minutos em álcool 70\% e 3 minutos em álcool 50\%; c) mergulho das lâminas em tionina a $0,25 \%$ por 1 minuto; d) banhos em água destilada (10 banhos); e) desidratação das lâminas como mencionado acima sendo que o tempo de cada banho nessa etapa é de 2 minutos; f) após banho em xilol as lâminas foram cobertas com DPX (Sigma Chemical, MO, USA) e lamínulas de vidro.

\subsection{Técnica de imuno-histoquímica pelo método de imunoperoxidase indireta}


A técnica de imuno-histoquímica no tecido nervoso é indicada para localizar, in situ, células gliais ou neuronais produtoras de determinados peptídeos ou proteínas estando estes localizados no corpo celular ou nas suas ramificações (dendritos e axônios). A técnica de imuno-histoquímica pelo método de imunoperoxidase indireta está baseada na utilização de um anticorpo específico (primário) que reconhece o antígeno (peptídeo ou proteína estudada) e posterior ligação de um anticorpo secundário ao anticorpo primário. Este anticorpo secundário apresenta um marcador (enzima) que na presença de seu substrato $\left(\mathrm{H}_{2} \mathrm{O}_{2}\right)$ e cromógeno (tetracloreto de diaminobenzidina- DAB) resulta na formação de um complexo colorido visível em microscopia de luz. Para tanto, foi utilizado o complexo avidina-biotina (ABC) (Vector Laboratories, CA, USA) para amplificação da marcação e intensificação da mesma através do uso da solução de sulfato-níquel-amônia (NAS) (Fisher Scientific, NJ, USA).

Para a técnica de imuno-histoquímica do TCAP-1 foi utilizado o anticorpo primário policlonal de coelho anti-TCAP-1 de camundongo (1:1700) gentilmente fornecido pelo Dr. David A. Lovejoy da Universidade de Toronto, Canadá. Para a imuno-histoquímica da TEN 1 foi utilizado o anticorpo policlonal obtido em camundongo anti-TEN 1 de humanos (1:500, H00010178-A01, Abnova, CA, USA).

A técnica de imuno-histoquímica foi utilizada inicialmente em duas etapas: teste de titulação e teste de adsorção. O teste de titulação teve por objetivo determinar a concentração ideal de anticorpo primário tanto para TCAP-1 quanto para TEN 1. Este teste seguiu protocolo padronizado pelo Laboratório de Neuroanatomia Química do Prof. Dr. Jackson, que será descrito a seguir, utilizando concentrações crescentes do anticorpo primário durante a incubação no tecido nervoso (anti-TCAP-1 - 1:500; 1:1000; 1:1500; 1:1700; 1:2000; 1:3000 e anti-TEN 1- 1:500, 1:1000 e 1:1500). O protocolo padronizado para a reação imunohistoquímica seguiu os seguintes passos: a) 6 lavagens de 5 minutos em KPBS 0,02M; b) inibição da peroxidase endógena por 30 minutos com solução de $\mathrm{H}_{2} \mathrm{O}_{2} \quad 0,3 \%$ obtida pela diluição de $0,5 \mathrm{ml}$ de $\mathrm{H}_{2} \mathrm{O}_{2}$ a $30 \%$ em $50 \mathrm{ml}$ de KBPS; c) 6 lavagens de 5 minutos em KPBS 0,02M até que não haja mais bolhas no tecido; d) preparo da solução contendo KPBS "loaded" (KPBS 0,02M + 0,03\% triton X-100), soro normal de burro (Jackson ImmunoReserch, PA, USA) e anticorpo primário anti-TCAP-1 ou anti-TEN 1 na 
concentração desejada e incubação dos cortes histológicos por 48h; e) Após as 48h, segue em 6 lavagens de 5 minutos em KPBS $0,02 \mathrm{M}$; f) preparo da solução de anticorpo secundário biotinilado anti-coelho (para TCAP-1) ou anti-camundongo (para TEN 1) na concentração de 1:800 e incubação dos cortes por $1 \mathrm{~h}$; g) 6 lavagens de 5 minutos em KPBS 0,02M; h) incubação em solução do complexo avidina-biotina, ambas na concentração de 1:100, em solução de KPBS 0,02M por 1h; i) 3 lavagens de 5 minutos em KPBS 0,02M; j) 3 lavagens de 5 minutos em tampão acetato ( $\mathrm{pH}$ 6,5) ;k) Revelação da reação de imuno-histoquímica através da solução de tampão acetato e NAS a 5\% diluído em tampão acetato e tetracloreto de diaminobenzidina (DAB) (0,02\%) (Sigma Chemical, MO, USA) acrescida de $\mathrm{H}_{2} \mathrm{O}_{2}$ a $30 \%$ $(0,003 \%) ; \mathrm{h})$ após, os cortes foram montados em lâminas gelatinizadas e secos a temperatura ambiente por 3 dias ou em estufa a $37^{\circ} \mathrm{C}$ por aproximadamente $18 \mathrm{~h}$, sendo posteriormente submetidos a bateria de desidratação que iniciou-se com 10 mergulhos em álcool 50\% e 70\%; banhos de 4 minutos em álcool 95\%; banhos de 6 minutos em álcool 100\%; banhos de 3 minutos em xilol, sendo logo após as lâminas cobertas com DPX (Sigma Chemical, MO, USA) e lamínulas de vidro.

O teste de adsorção foi utilizado para verificar a especificidade do anticorpo primário anti-TCAP-1. Este teste foi realizado em cortes histológicos que apresentaram corpos neuronais TCAP-1 imunorreativas (TCAP-1-ir) ao teste de titulação. O teste de adsorção consiste na realização da técnica imuno-histoquímica descrita acima com utilização de concentração fixa e ideal do anticorpo anti-TCAP-1, previamente determinado pelo teste de titulação, e concentrações crescentes do peptídeo TCAP-1 (concentração inicial de $1 \mathrm{mg} / \mathrm{ml}$ ) gentilmente fornecido pelo Dr. David A. Lovejoy. A etapa inicial do teste de adsorção constitui na diluição do peptídeo TCAP-1 que se encontrava liofilizado. O peptídeo liofilizado foi diluído em PBS $1 X$ com auxílio de vapor de peróxido de amônia, obtendo uma solução final de $1 \mathrm{mg} / \mathrm{ml}$ do referido peptídeo. Em prosseguimento, foi realizado a préadsorção entre o peptídeo TCAP-1 e o anticorpo TCAP-1 (titulação adequada, 1:1700) conforme especificado abaixo sendo $\mathrm{P}$ a concentração de peptídeo e A do anticorpo:

1) P: $1 \mathrm{mg} / \mathrm{ml}=200 \mu 1$ de peptídeo TCAP- $1+\mathrm{A}=1,8 \mu 1$ anti-TCAP-1

2) P: $0,5 \mathrm{mg} / \mathrm{ml}=100 \mu 1$ de peptídeo TCAP-1 + A = 1,8 $\mu 1$ anti-TCAP-1 + 98,2 $\mu 1 \mathrm{KPBS}$ $0,02 \mathrm{M} \mathrm{pH} \mathrm{7,4}$

3) P: $0,1 \mathrm{mg} / \mathrm{ml}=25 \mu \mathrm{l}$ de peptídeo TCAP-1 $+\mathrm{A}=1,8 \mu \mathrm{l}$ anti-TCAP-1 $+\quad$ 173,2 $\mu 1$ KPBS 0,02M pH 7,4 
4) P: $0,05 \mathrm{mg} / \mathrm{ml}=10 \mu 1$ de peptídeo TCAP-1 + A = 1,8 $\mu 1$ anti-TCAP-1 + 188,2 $\mu 1$ KPBS 0,02M pH 7,4

5) $\mathrm{P}: 0,01 \mathrm{mg} / \mathrm{ml}=2 \mu \mathrm{l}$ de peptídeo TCAP-1 $+\mathrm{A}=1,8 \mu \mathrm{l}$ anti-TCAP-1 + 196,2 $\mu 1$ KPBS 0,02M pH 7,4

6) Controle: $\mathrm{A}=1,8 \mu \mathrm{l}$ anti-TCAP-1 + $200 \mu \mathrm{KPBS}$ 0,02M pH 7,4

Após a pré-adsorção de cada concentração, as soluções permaneceram aproximadamente $18 \mathrm{~h}$ em mesa agitadora a $4{ }^{\circ} \mathrm{C}$, sendo posteriormente completadas com KPBS "loaded" e soro normal de burro (Jackson ImmunoReserch, PA, USA) para volume final de $3000 \mu$ l. Em seguida realizou-se o protocolo de imuno-histoquímica já descrito acima se iniciando nas lavagens em KPBS 0,02M, inibição da peroxidase endógena e incubação do anticorpo primário utilizando a solução de anticorpo + peptídeo completada para o volume de $3000 \mu 1$. Além do teste de adsorção vale ser ressaltado que foi realizado a omissão do anticorpo primário para controle da técnica de imuno-histoquímica tanto para TCAP-1 quanto para TEN 1.

Após os procedimentos controles iniciais, séries de cortes histológicos do SNC de três primatas não-humanos da espécie Cebus apella foi submetida ao método de imunoperoxidase para o mapeamento da distribuição do TCAP-1 no neuroeixo. A imunohistoquímica, por meio deste método, também foi realizada para TEN 1 em alguns cortes histológicos de séries adjacentes das utilizadas para TCAP-1 afim de observamos se os locais de imunorreatividade correspondem entre TCAP-1 e TEN-1.

\subsection{Técnica de imuno-histoquímica pelo método de dupla imuno-fluorescência}

Para melhor visualização das regiões que apresentaram co-localização de TEN 1 e TCAP-1 foi empregada a técnica de imuno-histoquímica pelo método de dupla imunofluorescência. Esta técnica baseia-se nos mesmos princípios da técnica de imuno-histoquímica descrita acima, porém com evidência da região imunomarcada através da ligação do anticorpo secundário, conjugado a um fluoróforo, ao anticorpo primário. O protocolo utilizado seguiu as seguintes etapas: a) 6 lavagens dos cortes histológicos em KPBS 0,02M por 10 minutos; b) 
bloqueio das ligações inespecíficas com solução contendo KPBS “loaded” (KPBS 0,02M + 0,03\% triton X-100) e soro normal de burro (Jackson ImmunoResearch, PA, USA) por 1 hora; c) incubação no anticorpo primário anti-TCAP-1 (1:50) por 24horas; d) 3 lavagens de 5 minutos em KPBS 0,02M; e) preparo e incubação dos cortes em solução de anticorpo secundário biotinilado anti-coelho gerado em burro conjugado com Cy3 (1:200, Jackson ImmunoResearch, USA) por 1 hora; f) 3 lavagens de 5 minutos em KPBS 0,02M; g) incubação no anticorpo primário anti-TEN1 (1:50) por 24horas em solução de KPBS "loaded" e soro normal de burro; h) 3 lavagens de 5 minutos em KPBS 0,02M; i) e) incubação no anticorpo secundário biotinilado anti-camundongo gerado em burro (1:100, Jackson ImmunoResearch, USA) por 1 hora; j) 3 lavagens de 5 minutos em KPBS 0,02M; k) incubação em solução de KPBS "loaded" e estreptavidina conjugada com diclorotriazinolamino fluoresceína (DTAF) por 1 hora (1:200, Jackson ImmunoResearch, USA). Após lavagem em KPBS 0,02M os cortes foram montados em lâminas gelatinizada, secos em temperatura ambiente e cobertos com meio de montagem a base de glicerol e lamínula de vidro.

Todos os procedimentos das técnicas de imuno-histoquímica e de histoquímica pela técnica de Nissl foram realizados tanto no Laboratório de Neuroanatomia Química sob co-orientação do Prof. Dr. Jackson Cioni Bittencourt (Departamento de Anatomia, ICB IIIUSP) quanto no departamento de Ciências Básicas sob orientação do Prof. Dr. Cláudio A. Casatti (Faculdade de Odontologia de Araçatuba - UNESP/SP).

\subsection{Forma de análise dos resultados, aquisição e edição das imagens}

Os resultados obtidos pelos métodos de hibridização in situ e imuno-histoquímica pelo método de imunoperoxidase foram analisados em microscópio de luz (Leica DMR, Wetzlar, Alemanha) através da análise em campo claro para localização dos corpos celulares TCAP-1 imunorreativas (TCAP-1-ir) e em campo claro e escuro para verificação dos depósitos dos grânulos de prata após HIS para TCAP-1. Os dados de imunorreatividade e expressão do RNAm para TCAP-1 foram dispostos em tabela de maneira qualitativa. A análise da co-localização de TCAP-1/TEN 1 pelo método de dupla imuno-fluorescência foi feita em microscópio de epifluorescência (Optiphot-2, NIKON, Japão) com fonte de luz de 
mercúrio de alta pressão (HB 101001 AF-NIKON) ajustado com conjuntos de filtros específicos para visualização dos fluorocromos Cy3 e DTAF.

Para auxiliar no mapeamento e nomenclatura dos grupamentos neuronais imunorreativos e que expressam o RNAm para TCAP-1 utilizamos, além dos cortes histológicos corados em Nissl que nos auxiliam na referência citoarquitetônica, as seguintes referências : atlas "A Stereotaxic Atlas of the Brain of the Cebus Monkey (Cebus apella)" (Manocha, Shantha e Bourne, 1968), "The Rhesus Brain Monkey" (Paxinos, Petrides e Toga, 2009) , “A stereotaxic atlas for Cebus Monkey”(Eidelberg e Saldias, 1960), “Terminologia Anatômica" (Sociedade Brasileira de Anatomia, 2001) e "The human nervous system" (Paxinos e Mai, 2004).

Para a aquisição das imagens microscópicas foi utilizado câmera digital da marca Nikon - digital sight DS Ri1 (Nikon Corporation, Japão) acoplada ao microscópio da marca Leica DMR (Leica DMR, Wetzlar, Alemanha) utilizando-se o software de captura de imagens NIS - Elements BR 3.0 (Nikon Corporation, Japão). Também foi utilizado lupa da marca Zeiss AxioCam MRc5 (Carl Zeiss MicroImaging, Alemanha) e software de imagens Axio Vision 4.5 (Carl Zeiss MicroImaging, Alemanha) para captura das imagens macroscópicas. Todas as imagens capturadas foram editadas no programa Adobe Photoshop CS2 para melhor apresentação e organização dos resultados e somente ajustadas com relação ao brilho e contraste das mesmas. 


\subsection{Procedimentos controles}

5.1.1 Hibridização in situ: análise das sequências do TCAP-1 do Cebus apella

A seqüência subclonada do Cebus apella, empregada para obtenção da sonda utilizada na HIS, foi analisada através de "software" fornecido pelo site de acesso público Expasy (Translate e Blast, USA), como propósito de confirmar sua identidade com similares de primatas, aves, roedores e anfíbios. Nesta análise, foi realizada a conversão da seqüência exônica do DNA do Cebus apella em aminoácidos através de um processo computacional de transcrição. A identidade entre a seqüência do TCAP-1 do Cebus apella com outras espécies foi elevada, sendo notada uma correspondência entre 92-100\% (figura 3). Estes resultados reforçam a especificidade da sonda de TCAP-1 empregada no presente estudo. Através da análise da seqüência do TCAP-1 do Cebus apella também foi possível estabelecer um mapa com as possíveis enzimas de restrição que poderiam ser utilizadas para a linearização do plasmídeo durante a etapa de transcrição da sonda (figura 4).

Figura 3 - Análise da identidade entre as sequências de TCAP-1 do Cebus apella com primatas não humanos e humanos, aves, roedores e anfíbios através do software BLAST.

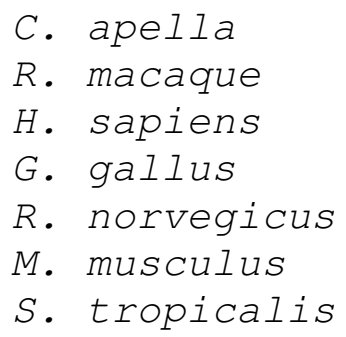

C. apella

QQLLSTGRVQGYDGYFVLSVEQYLELSDSANNIHF QQLLSTGRVQGYDGYFVLSVEQYLELSDSANNIHF QQLLSTGRVQGYDGYFVLSVEQYLELSDSANNIHF QQLLNTGRVQGYDGYFVLSVEQYLELSDSANNIHF QQLLGTGRVQGYDGYFVLSVEQYLELSDSANNIHF QQLLGTGRVQGYDGYFVLSVEQYLELSDSANNIHF QQLLNTGRVQGYDGYFVISVEQYPELSDSANNIHF

NOTA: Observar a elevada identidade entre essas espécies, mostrando uma alta conservação do TCAP-1. Em vermelho é evidenciado os aminoácidos que foram substituídos entre as espécies.

FONTE: Torres, KR (2012). 
Figura 4 - Representação esquemática da seqüência da fita de DNA do plasmídeo juntamente com a representação da fita do inserto de DNA para TCAP-1 do Cebus apella (amarelo).

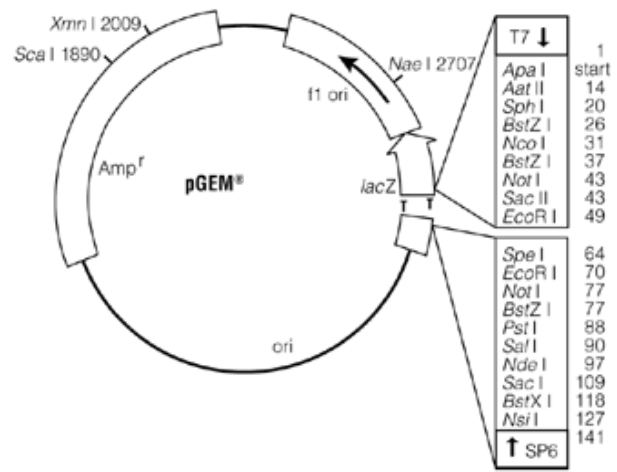

T7 início da transcrição.

5'...TGTAA TACGA CTCAC TATAG GGCGA ATTGG GCCCG ACGTC GCATG CTCCC GGCCG CCATG

3'... ACATT ATGCT GAGTG ATATC CCGCT TAACC CGGGC TGCAG CGTAC GAGGG CCGGC GGTAC

T7 Promoter

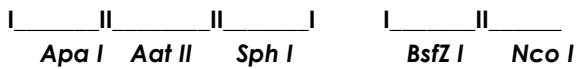

GCGGC CGCGG GAATT CGATT3'

Apa I Aat II Sph I

Bsfz I Nco I

CGCCG GCGCC CTTAA GCTA

$$
\frac{\text { III }}{\text { Not I I I I }}
$$

Not I

ACGTCAGTGITGAATGGGAGGACTAGACGGITTGCAGATATTCAGCTCCAGCACGGAGCACTGTGCTTCAACATCCGGTATGGGACAACTGTCGAAGAGGAAA AGAATCACGTGTTGGAAATTGCCAGACAGCGCGCCGTGGCCCAGGCCTGGACTAAGGAACAAAGAAGGCTGCAAGAGGGGGAAGAGGGGATTAGGGCAT GGACAGAGGGGGAAAAGCAGCAGCTTTTGAGCACTGGGCGGGTACAAGGTTACGATGGGTATTTGITTTGTTGITGAGCAGTATTTAGAACTTTCTGACAGTGCC AACAATATTCACTTATGAGACAGAGTGAAATAGGCAGGAGG

ATCAC TAGTG AATTC GCGGC CGCCT GCAGG TCGAC CATAT GGGA GAGCT CCCAA CGCGT TGGAT

\begin{tabular}{|c|c|c|c|c|c|c|c|}
\hline II & II & & II & II & 1 & II & III \\
\hline Spe I & ECOR I & Not I & Pst I & Sall & Nde I & Sac I & BstX I \\
\hline
\end{tabular}
3'TTAGTG ATCAC TTAAG CGCCG GCGGA CGTCC AGCTG GTATA CCCT CTCGA GGGTT GCGCA ACCTA

GCATA GCTTG AGTAT TCTAT AGTGT CACCT AAAT ....

CGTAT CGAAC TCATA AGATA TCACA GTGGA TTTA ....

$\overline{N s i}$

SP6 Promoter

LEGENDA: Em verde temos a seqüência do primer utilizado para a amplificação do DNA do TCAP-1 e em negrito as enzimas T7 e SP6 que são de leitura e as demais de restrição.

FONTE: Torres, KR (2012). 


\subsubsection{Imuno-histoquímica: teste de titulação}

A utilização da técnica de imuno-histoquímica pelo método de imunoperoxidase indireta possibilitou, inicialmente, a determinação da concentração ideal do anticorpo primário através do teste de titulação tanto para TCAP-1 (1:1700) quanto para TEN 1 (1:500). O teste de titulação para o anticorpo primário anti-TCAP-1 foi realizado em cortes histológicos do cerebelo e possibilitou, através da utilização de concentrações crescentes desse anticorpo na técnica de imuno-histoquímica $(1: 500 ; 1: 1000 ; 1: 1500 ; 1: 1700 ; 1: 2000$; 1:3000) a determinação da concentração ideal a ser utilizada. Foi considerada como ideal a concentração de 1:1700 devido a ausência de marcação de fundo e evidente marcação verificada nos corpos neuronais da camada de Purkinje do cerebelo (Pk) e dos núcleos do cerebelo (figura 5). Nas concentrações menores do que 1:1700 foi verificado redução gradativa do padrão de marcação enquanto que em concentrações maiores foi verificado ausência ou marcação neuronal parcial com intensa marcação de fundo. Além disso, tem-se notado que o padrão de marcação para TCAP-1 mostra-se amplamente difuso no corpo e prolongamentos neuronais. Através do teste de titulação também foi verificado a concentração ideal do anticorpo primário anti-TEN 1 (1:500, 1:1000 e 1:1500) em cortes histológicos do cerebelo. Os resultados obtidos demonstraram a presença de corpos neuronais TEN 1 imunorreativos (TEN 1-ir) em alguns perfis neuronais na camada de Purkinje do cerebelo (Pk) e nos núcleos do cerebelo na concentração do anticorpo primário de 1:500 (figura 6, dados mostrados para o núcleo cerebelar medial -Med). 


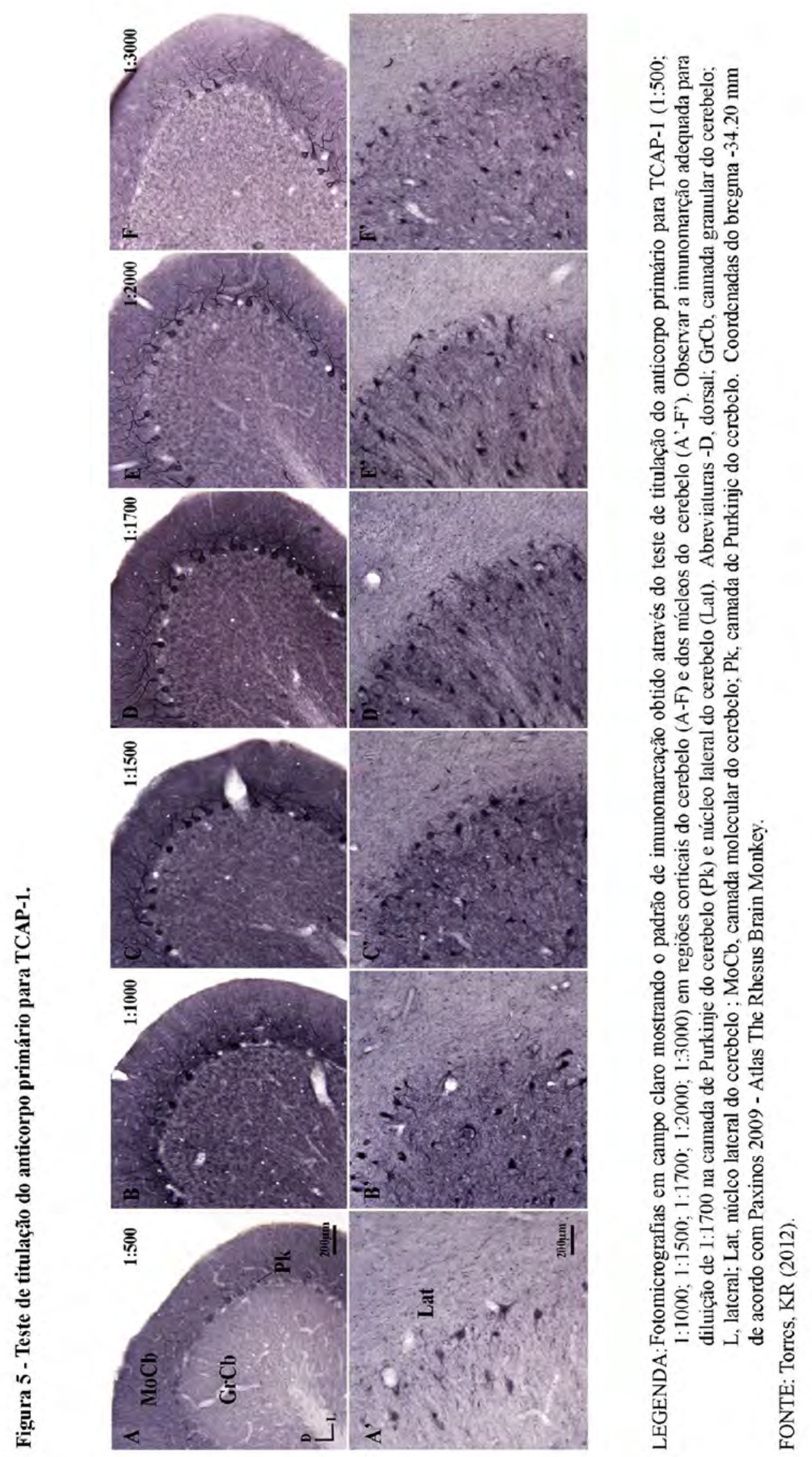


Figura 6 - Teste de titulação do anticorpo primário para TEN 1.
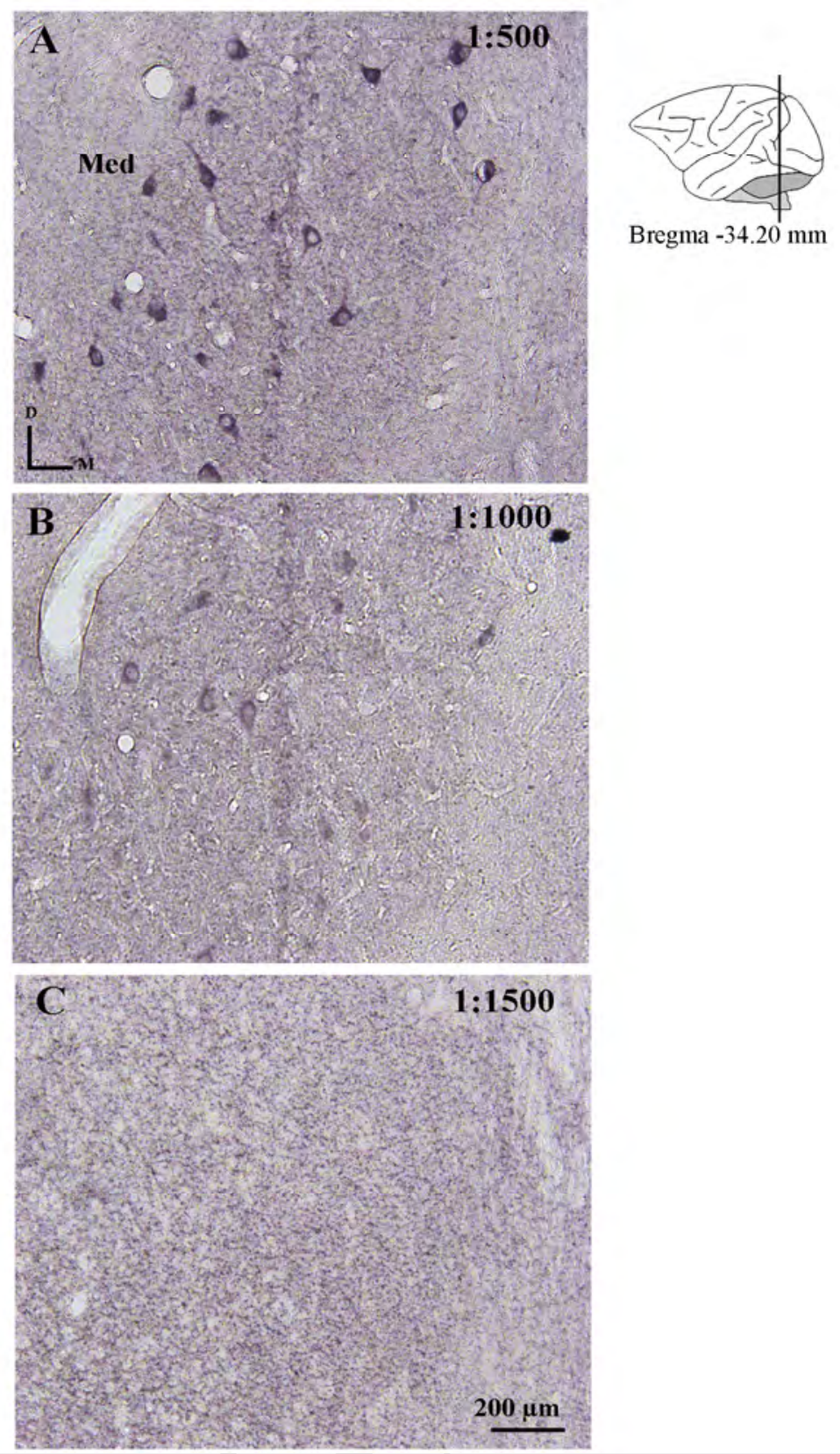

LEGENDA: Fotomicrografias em campo claro mostrando o padrâo de imunomarcaçào obtido através do leste de titulaçâo do anticorpo primário para TEN I (1:500: 1:1000: 1:1500) em regiōes dos múcleos do cerebelo. Observar a imunomarçẫo adequada para diluição de 1:500 no núcleo cerebelar medial (Med). Coordenadas do bregma $-34.20 \mathrm{~mm}$ de acordo com Paxinos 2009 - Atlas The Rhesus Brain Monkey.

FONTE: Torres, KR(2012). 


\subsubsection{Imuno-histoquímica: teste de adsorção e omissão do anticorpo primário}

O teste de adsorção para TCAP-1 foi realizado para verificar se as regiões imunorreativas ao anticorpo anti-TCAP-1 estavam sendo marcadas devido à especificidade do anticorpo no reconhecimento do peptídeo TCAP-1. Este teste foi feito com o peptídeo TCAP1 em diferentes concentrações.

Os resultados para este teste revelaram uma consistente especificidade do anticorpo empregado neste estudo, pois não houve imunomarcações nas soluções mais concentradas de peptídeo. A imunorreatividade foi verificada nos cortes histológicos incubados com menor concentração do peptídeo e com solução controle (presença do anticorpo primário e ausência do peptídeo) (figura 7 e tabela 2).

Um segundo controle da técnica imuno-histoquímica foi realizada com a omissão do anticorpo primário (TCAP-1 e TEN 1). Os resultados deste controle mostraram total ausência de marcação, revelando que os reagentes empregados na técnica de imunohistoquímica não induziram marcações inespecíficas.

Visto que os procedimentos controle da técnica de imuno-histoquímica mostraram-se favoráveis, séries completas de cortes histológicos do SNC do Cebus apella foram submetidas ao método de imunoperoxidase para TCAP-1 a fim de realizar o mapeamento detalhado da distribuição desse peptídeo. Além disso, alguns cortes histológicos adjacentes também foram submetidos à imunoperoxidase indireta para TEN 1 e a dupla imunofluorescência para TEN1/TCAP-1, com o intuito de verificar se há correspondência de distribuição entre TEN 1 e TCAP-1 e em algumas áreas encefálicas. 


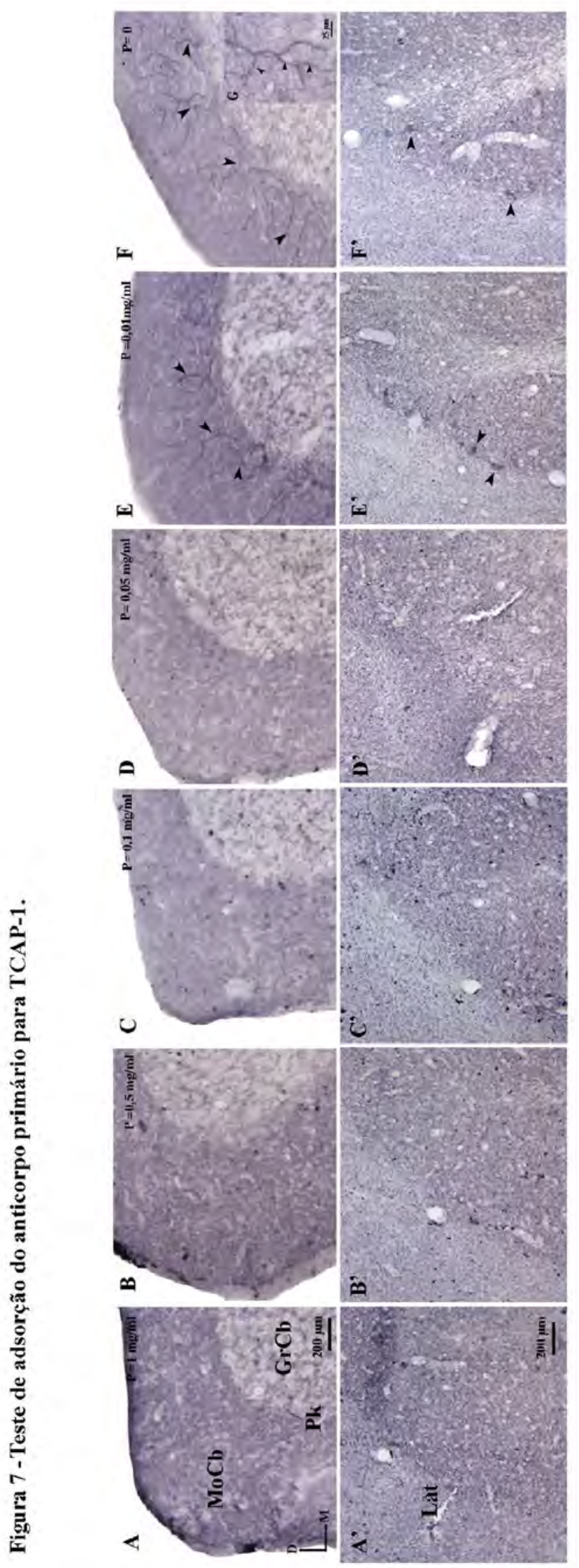

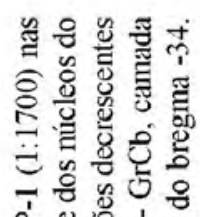

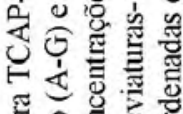

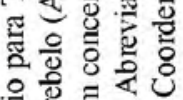

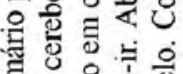

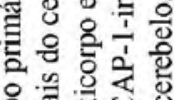

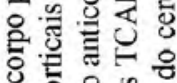

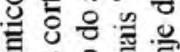
응 㣢 원용

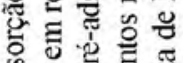

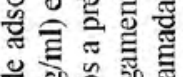

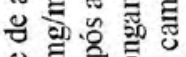

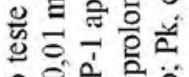
웡 进它 를 플

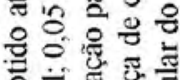

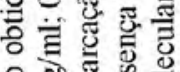

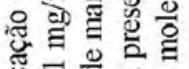

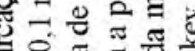

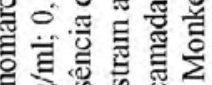

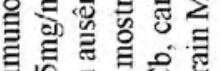

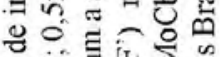

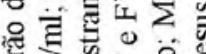

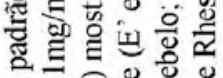

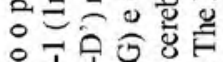

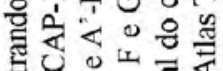
뭉

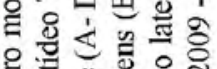

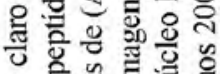

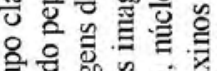

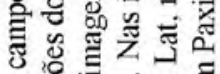

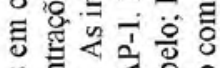

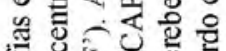

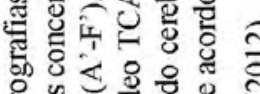

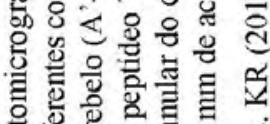

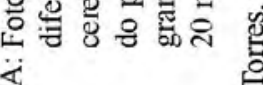
啰 望 
Tabela 2 - Característica da competição do peptídeo TCAP-1 no SNC do Cebus apella através do teste de adsorção

\begin{tabular}{|c|c|c|}
\hline \multirow{2}{*}{$\begin{array}{c}\text { Peptídeo } \\
\text { (mg/ml) }\end{array}$} & \multicolumn{2}{|c|}{ TCAP-1-ir (cerebelo) } \\
\hline & $\begin{array}{l}\text { camada de } \\
\text { Purkinje }\end{array}$ & $\begin{array}{l}\text { núcleos } \\
\text { cerebelares }\end{array}$ \\
\hline 1 & - & - \\
\hline 0,5 & - & - \\
\hline $\mathbf{0 , 1}$ & - & - \\
\hline $\mathbf{0 , 0 5}$ & - & - \\
\hline $\mathbf{0 , 0 1}$ & + & + \\
\hline Controle & + & + \\
\hline
\end{tabular}

LEGENDA: Sinal de (+) e (-) presença e ausência, respectivamente, de imunorreatividade em corpos neuronais das regiões cerebelares (córtex- camada de purkinje e núcleos cerebelares) usando como referência o grupo controle (anticorpo primário não preadsorvido com o peptídeo TCAP-1).

FONTE: Torres, KR (2012).

\subsection{Análise dos cortes histológicos submetidos à hibridização in situ e imuno- histoquímica para TCAP-1}

A análise dos resultados de hibridização in situ (HIS) e de imuno-histoquímica mostrou elevada correspondência de distribuição do RNAm e do peptídeo TCAP-1 nos diversos territórios encefálicos. Para melhor visualização dos resultados estes foram descritos por regiões encefálicas: telencéfalo, diencéfalo, tronco encefálico, cerebelo e medula espinal. 


\subsubsection{Telencéfalo}

O telencéfalo do Cebus apella é a região encefálica com maior área de tecido nervoso sendo composto por regiões corticais e subcorticais como córtex cerebral e amígdala, respectivamente. $\mathrm{O}$ telencéfalo é dividido em quatro lobos que são delimitados por sulcos e fissuras principais. O lobo frontal do Cebus apella, a semelhança do lobo frontal do macaco Rhesus, localiza-se anteriormente ao sulco central (cs) e é delimitado inferiormente pela fissura lateral (If); o lobo temporal localiza-se inferiormente a If; o lobo parietal estende-se posteriormente ao cs até o sulco parietooccipital (pos) e o lobo occipital localizado posteriormente ao sulco pos e é delimitado inferiormente pelo sulco occipital inferior (ios) (figura 8).

Os resultados observados para HIS nesta região encefálica apresentou sinal de hibridização tanto na análise do filme radiográfico (figura 9) quanto em microscopia de luz (campo claro e escuro). A imunorreatividade também foi constatada em corpos neuronais de várias áreas telencefálicas. Nas áreas corticais do telencéfalo, especificamente no isocórtex, a presença do RNAm para TCAP-1 foi discretamente notada enquanto que a imunorreatividade para o peptídeo TCAP-1 foi melhor observada sendo que ambos RNAm e peptídeo foram observados nos corpos neuronais da camada III e V. No lobo frontal, em particular no córtex pré-frontal (situado anteriormente ao sulco arqueado inferior - iar e arqueado superior - sar) (figura 8), foi observado corpos neuronais TCAP-1-imunorreativos (TCAP-1-ir) na camada III e V da área 9L e 9M (figura 10B, dados mostrados para área 9L). Na área do córtex motor primário, área 4(F1), nota-se corpos neuronais TCAP-1-ir na camada III e V (figura 10E, dados mostrados para área 4(F1)). No lobo parietal a imunomarcação também foi observada nas camadas III e V da área 3a e 3b do córtex somatosensorial. No arquicórtex foi notada que a formação hipocampal apresentou tanto RNAm quanto imunorreatividade na região do subículo e nas camadas CA1-4 e, apenas imunorreatividade restrita a terminações nervosas no giro denteado (figura 11D, dados mostrados para CA3).

Nas áreas subcorticais do telencéfalo foi observado expressão do RNAm para TCAP-1, devido a presença dos depósitos dos grânulos de prata no corpo neuronal, e imunorreatividade para TCAP-1 nos núcleos do complexo amigdalóide como o núcleo medial 
da amígdala (Me), núcleo central da amígdala (Ce), área amigdalóide anterior (AA) e área amigdalohipocampal (AHi) (figura 11C, dados mostrados para Me e AA).

Nos núcleos da base, como pálido ventral (VP), globo pálido interno e externo (IGP e EGP, respectivamente) houve corpos neuronais TCAP-1-ir e positivos para HIS. Nos núcleos da região septal como núcleo horizontal da banda diagonal (HDB), núcleo vertical da banda diagonal (VDB) e núcleo basal (Meynert) (B) apresentaram corpos neuronais TCAP-1ir e depósitos do grânulos de prata que correspondem ao RNAm para TCAP-1 (figura 12, dados mostrados para o HDB).

Outras regiões telencefálicas que exibiram RNAm e o peptídeo TCAP-1 estão apresentadas na tabela de distribuição (tabela 3).

\subsubsection{Diencéfalo}

O diencéfalo do Cebus apella é constituído pelo epitálamo, tálamo, subtálamo, metatálamo e hipotálamo. O mapeamento da distribuição do TCAP-1tem demonstrado imunorreatividade e HIS em praticamente todas as regiões diencefálicas com exceção do epitálamo.

O tálamo, situado ventralmente a cada hemisfério cerebral apresentou expressão do RNAm e corpos neuronais TCAP-1-ir em grupos nucleares anteriores, mediais, dorsais, ventrais e posteriores do tálamo. Com exceção do núcleo talâmico anterodorsal e anterior ventral magnocelular que foi verificado somente imunorreatividade para TCAP-1. No metatálamo foi constatado corpos neuronais TCAP-1-ir e expressão do RNAm no núcleo geniculado lateral dorsal (DLG) e núcleo pré-geniculado (PrG) (Figura 13, dados mostrados para DLG).

O hipotálamo, que está localizado anterior e inferiormente ao tálamo e forma parte da parede lateral e assoalho do terceiro ventrículo. No sentido medio-lateral a partir do terceiro ventrículo o hipotálamo é divido em zona periventricular, zona medial e zona lateral (Saper, Akil e Watson, 1986). Na zona periventricular notamos imunorreatividade para TCAP-1 com corpos neuronais TCAP-1-ir no núcleo supra-óptico (SO). Neste núcleo também verificamos o RNAm para TCAP-1 no compartimento citosólico dos neurônios do SO (figura 
14). Na zona lateral verificamos corpos neuronais com expressão do RNAm e TCAP-1-ir no núcleo mamilar lateral (LM), área hipotalâmica lateral (LH) e na área hipotalâmica posterior (PH) (figura 11B, dados mostrados para LM)

Na região subtalâmica foi verificado expressão do RNAm e imunomarcação para TCAP-1 corpos neuronais da zona incerta (ZI) e do núcleo subtalâmico (STh).Outras regiões diencéfalicas imunorreativas e que expressam o RNAm para TCAP-1 estão apresentadas na tabela de distribuição (tabela 3).

\subsubsection{Tronco encefálico}

O tronco encefálico está situado entre a medula espinal e o diencéfalo e é dividido anatomicamente em: mesencéfalo, ponte e bulbo (figura 8). No mesencéfalo muitas áreas apresentaram corpos neuronais imunorreativos e que expressam o RNAm para TCAP-1 entre elas: campo retrorubral (RRF), substância negra, parte reticular (SNR), substância negra, parte lateral (SNL) e substância negra, parte compacta (SNC) (figura 15B, dados mostrados para SNL e figura 16 dados mostrado para SNR).

Na região da ponte e bulbo foi verificado RNAm e imunorreatividade para TCAP-1-ir em corpos neuronais do núcleo pontino (Pn), no núcleo coclear ventral, parte anterior (VCA) e parte posterior (VCP). No núcleo coclear dorsal (DC) foi verificada apenas imunorreatividade para TCAP-1. As demais regiões do tronco encefálico que apresentaram correspondência de distribuição entre RNAm e peptídeo foram: núcleo espinal do nervo trigêmio, parte interpolar ( $\mathrm{Sp5i}$ ), núcleo obscuro da rafe ( $\mathrm{ROb}$ ), nos núcleos pertencentes ao complexo olivar inferior como núcleo principal inferior da oliva (IOPr), núcleo olivar inferior dorsal (IOD) e núcleo olivar acessório medial (MAO) entre outros (figura 15 dados mostrados para DC e ROb). A distribuição detalhada dos neurônios TCAP-1-ir e que expressam o RNAm para TCAP-1 em outras regiões do tronco encefálico são apresentados na tabela 3.

\subsubsection{Cerebelo}

O cerebelo do Cebus apella localiza-se na fossa craniana posterior, dorsalmente a ponte e ao bulbo e póstero-inferiormente aos hemisférios cerebrais. Macroscopicamente é dividido no sentido látero-lateral em dois hemisférios cerebelares 
denominados de hemisférios laterais do cerebelo e uma região mediana a esses hemisférios denominada de verme do cerebelo (figura 8). O cerebelo é recoberto por uma região cortical denominada de córtex cerebelar, composto por substância cinzenta e branca, que se apresenta com várias dobras, semelhante ao córtex cerebral, sendo essas dobras denominadas de lóbulos separados uns dos outros por fissuras. Duas fissuras mais profundas dividem grupos de lóbulos em lobos cerebelares, sendo essas a fissura prima que separa o lobo anterior do lobo posterior (figura 8) e a fissura póstero-lateral que separa o lobo posterior do lobo flóculonodular. No córtex cerebelar, através de análise microscópica, nota-se que a substância cinzenta é composta por três camadas: camada molecular do cerebelo ( $\mathrm{MoCb})$, camada de Purkinje do cerebelo (Pk) e camada granular do cerebelo $(\mathrm{GrCb})$. Abaixo da camada granular encontra-se a substância branca que é composta predominantemente por axônios mielinizados que levam as aferências e eferências do cerebelo. Imersas na substância branca do cerebelo há os núcleos do cerebelo. Esses núcleos em primata não-humano são denominados de núcleo lateral do cerebelo (Lat), núcleo interpósito anterior do cerebelo (IntA), núcleo interpósito posterior do cerebelo (IntP) e núcleo cerebelar medial (Med) que correspondem ao núcleo denteado, emboliforme, globoso e do fastígio em primatas humanos (Paxinos G, 2009).

A imunorreatividade e a distribuição do RNAm para TCAP-1 foi observada nas regiões corticais e dos núcleos do cerebelo. No córtex cerebelar foi constatado imunorreatividade por toda a $\mathrm{Pk}$, porém, mais predominante no lobo posterior dos hemisférios laterais do cerebelo especialmente no lóbulo cerebelar 6 (Cb6), lóbulo simples (Sim), crus 1 do lóbulo ansiforme (Crus1), crus 2 do lóbulo ansiforme (Crus 2), lóbulo paraflocular posterior (PPFI) e lóbulo paraflocular dorsal (DPFI) (figura 17B e C evidencia o Sim). Outra característica interessante constatada no córtex cerebelar foi a presença de corpos celulares neuronais TCAP-1-ir na GrCb próximas ou distantes da Pk (figura 17B e C). Nos núcleos do cerebelo foi constatado marcação para TCAP-1 nos corpos neuronais do núcleo interpósito posterior do cerebelo (IntP), núcleo interpósito anterior do cerebelo (IntA), núcleo cerebelar medial (Med) e núcleo lateral do cerebelo (Lat) (figura 17D e E dados mostrados para Med e Lat, respectivamente). Destacamos aqui que o padrão de marcação dos corpos neuronais TCAP-1-ir mostraram-se semelhante tanto na região cortical quanto subcortical do cerebelo, com imunorreatividade difusa por todo o citosol das células neuronais. A localização da distribuição do RNAm para TCAP-1 tanto na porção cortical quanto nos núcleos do cerebelo 
seguiu as mesmas localizações de imunorreatividade descrita acima. Os dados de distribuição do TCAP-1 nas regiões cerebelares são apresentados na tabela 3 .

Para melhor visualização da distribuição do TCAP-1 no encéfalo, no que se refere a regiões imunorreativas, foi realizado esquema representativo da distribuição desse peptídeo que pode ser observada na figura 18.

\subsubsection{Medula espinal}

A medula espinal encontra-se localizada imediatamente abaixo do tronco encefálico e compreende de quatro seguimentos: cervical, torácico, lombar e sacral. Em todos os seguimentos é verificada a existência de uma organização geral da substância cinzenta sendo esta dividida em três colunas e dez lâminas. A coluna posterior (também denominado de corno dorsal) apresenta as lâminas de I a VI enquanto que a coluna intermédia (corno lateral) a lâmina VII. A coluna anterior (ou corno ventral) apresenta as lâminas VIII e IX sendo que nos seguimentos cervicais e lombossacral as células que constituem a lâmina VII se estendem para dentro da coluna anterior fazendo parte desta. A lâmina X está ao redor do canal central da medula espinal.

A imunorreatividade para TCAP-1 na medula espinal apresentou, com exceção do seguimento cervical, neurônios TCAP-1-ir nas lâminas VII ,VIII e IX, porém, também foi observado a presença de escassas células neuronais TCAP-1-ir nas demais lâminas medulares. A distribuição do RNAm para TCAP-1 nos seguimentos da medula espinal, e em algumas regiões do tronco encefálico, infelizmente não foram analisados devido a ausência de cortes histológicos submetidos ao método de HIS (evidenciado pelo sinal de * na tabela 3 ). 
Tabela 3 - Distribuição do peptídeo e do RNAm para TCAP-1 no SNC do Cebus apella

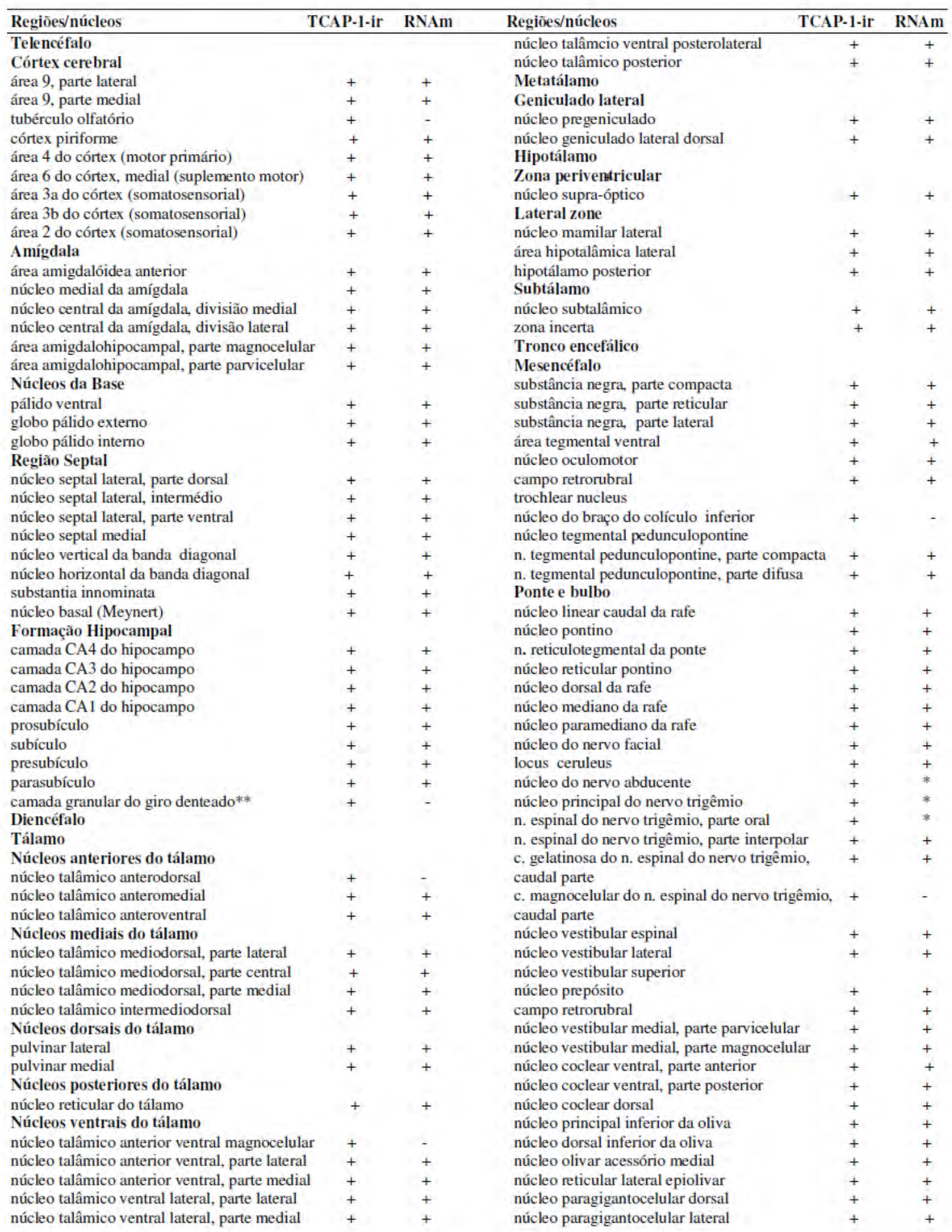

(continua) 
(continuação)

Ponte e bulbo

núcleo reticular gigantocelular

núcleo reticular gigantocelular, parte ventral

núcleo ambiguo

núcleo obscuro da rafe

núcleo reticular lateral, parte subtrigeminal

núcleo cuneato externo

núcleo reticular lateral

núcleo reticular dorsal

núcleo reticular intermédio

núcleo reticular ventral

núcleo motor dorsal do nervo vago

núcleo grácil

\author{
núcleo cuneiforme \\ núcleo do nervo acessório \\ Cerebelo \\ Córtex \\ camada de células de purkinje \\ Núcleos cerebelares \\ núcleo cerebelar medial \\ núcleo interpósito anterior \\ núcleo interpósito posterior \\ núcleo cerebelar lateral \\ Medula espinal \\ lâmina VII \\ lâmina VIII \\ lâmina IX
}

LEGENDA: Sinal de (+) presença de corpos neuronais imunorreativos (TCAP-1-ir) e que expressam o RNAm para TCAP-1. Sinal de (-) ausência de corpos neuronais imunorreativos (TCAP-1-ir) e que expressam o RNAm para TCAP-1. Sinal (*) ausência de cortes histológicos submetidos ao método de HIS. Sinal $(* *)$ imunorreatividade restrita a terminações nervosas.

FONTE: Torres, KR (2012). 
Figura 8 - Fotografias macroscópicas do encéfalo do Cebus apella.

A

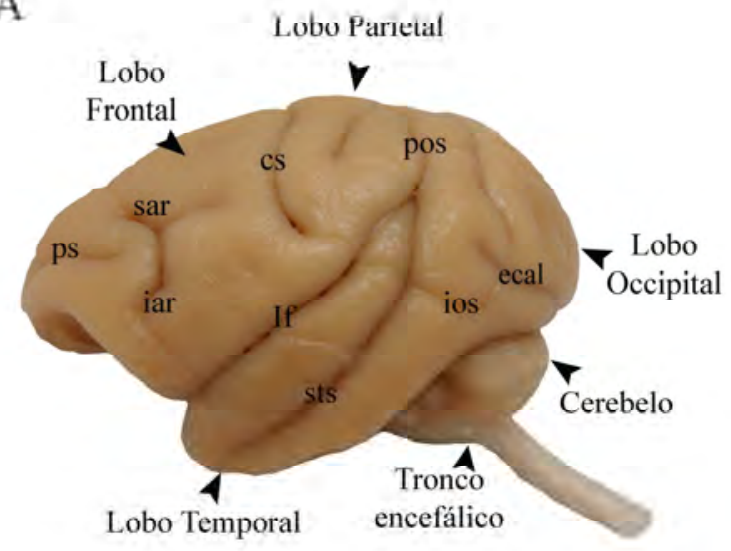

B

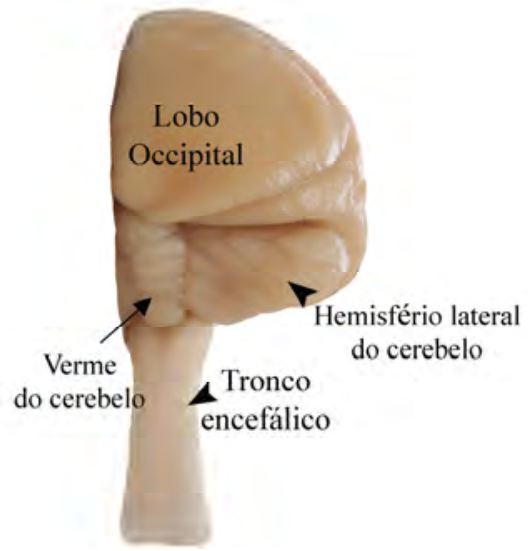

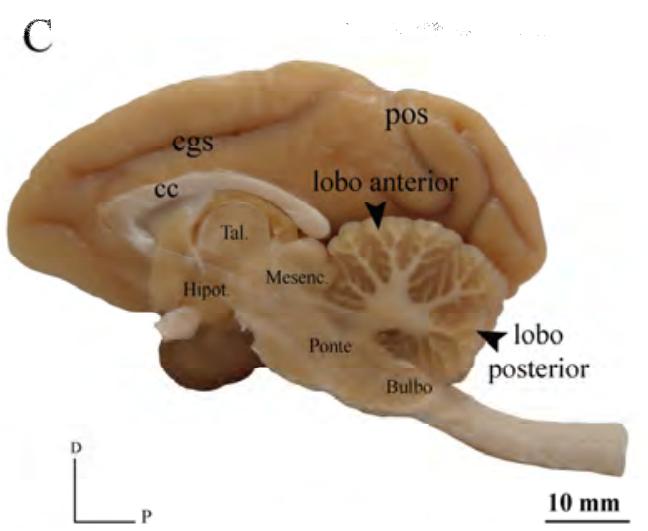

LEGINDA.Em (A) Vista lateral do encéfalo derionstrando os lobos encéfalicos, cabeças de setas, e os principais sulcos que os delimitam. Outras estruturas que compõe o encéfalo também sâo apontadas nessa figura como o cerebelo e o tronco encefálico. Em (B) vista posterior do encéfalo, mostrando o lobo occipital, tronco encefálico e a preșença dos hemisférios cerebelares: hemisférios lateral do cerebelo e verme do cerebelo. Em (C) vista medial em corte sagital mostrando a divisão dos lobos cerebelares anterior e posterior, cabeça de setas, observar tambèm algumas estruturas que compôe o diencéfalo e o tronco encefálico. Abreviaturas- cc, eorpo caloso; cgs, sulco cingulado; es, sulco central; D. dorsal; ecal. sulco calcarino externo; hipot., hipotálamo; iar. sulco arqueador inferior: If. fissura lateral; ios; sulco occipital inferior; mesenc, mesencéfalo; P, posterior; pos, sulco parietooccipital; ps, sulco principal; sar, sulco arqueado superior; sts, sulco temporal superior; tal., tálamo.

FWNTE: IOTE KR(2012). 
Figura 9 - Análise dos filmes radiográficos após hibridização in situ para TCAP-1.
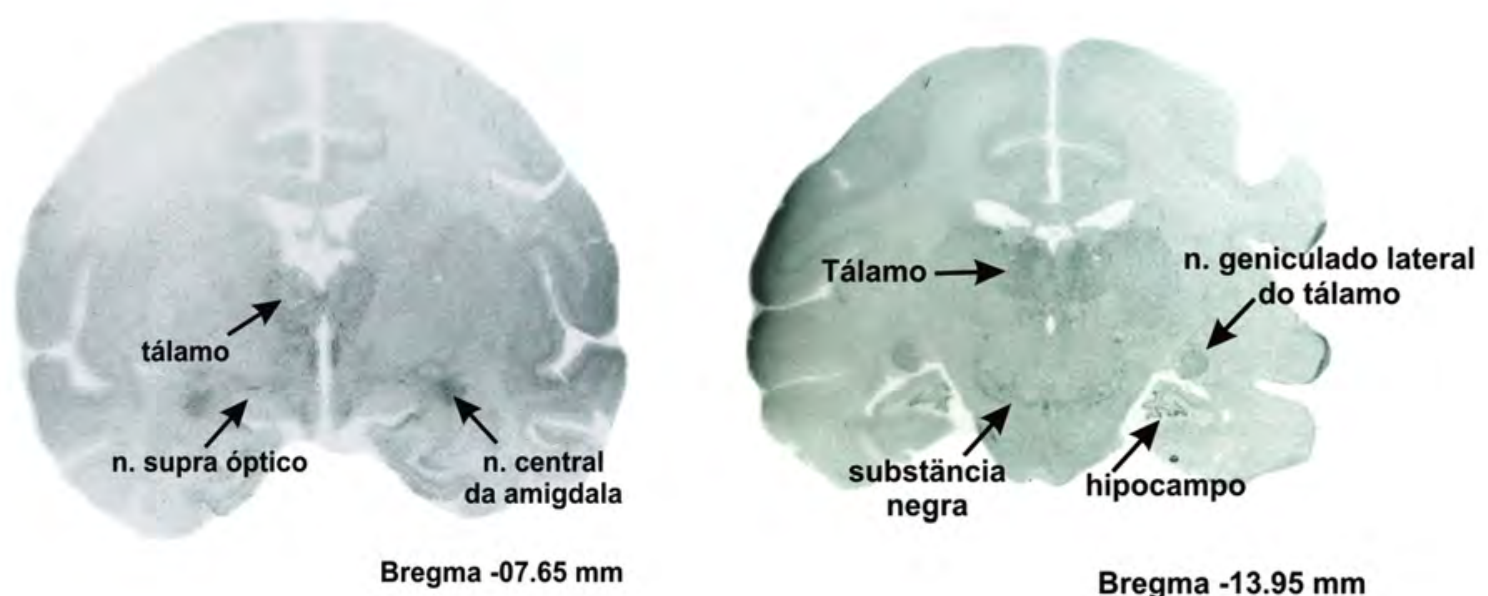

Bregma $-13.95 \mathrm{~mm}$

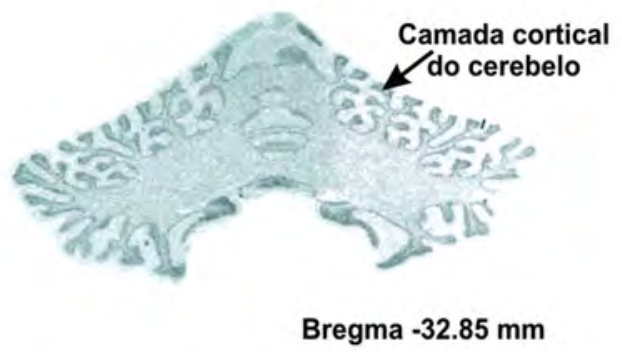

LEGENDA: As áreas indicadas pelas setas mostram as regiões do tecido nervoso com sinal de hibridização positivo devido hibridização com sondas espécie-específica marcadas com radioisótopo ${ }^{35} \mathrm{~S}$. Coordenadas do bregma de acordo com Paxinos, 2009- Atlas de Rhesus Brain Monkey.

FONTE: Torres, KR (2012). 
Figura 10 - Distribuição dos neurônios TCAP-1 imunorreativos em regiões telencefálica cortical do Cebus apella
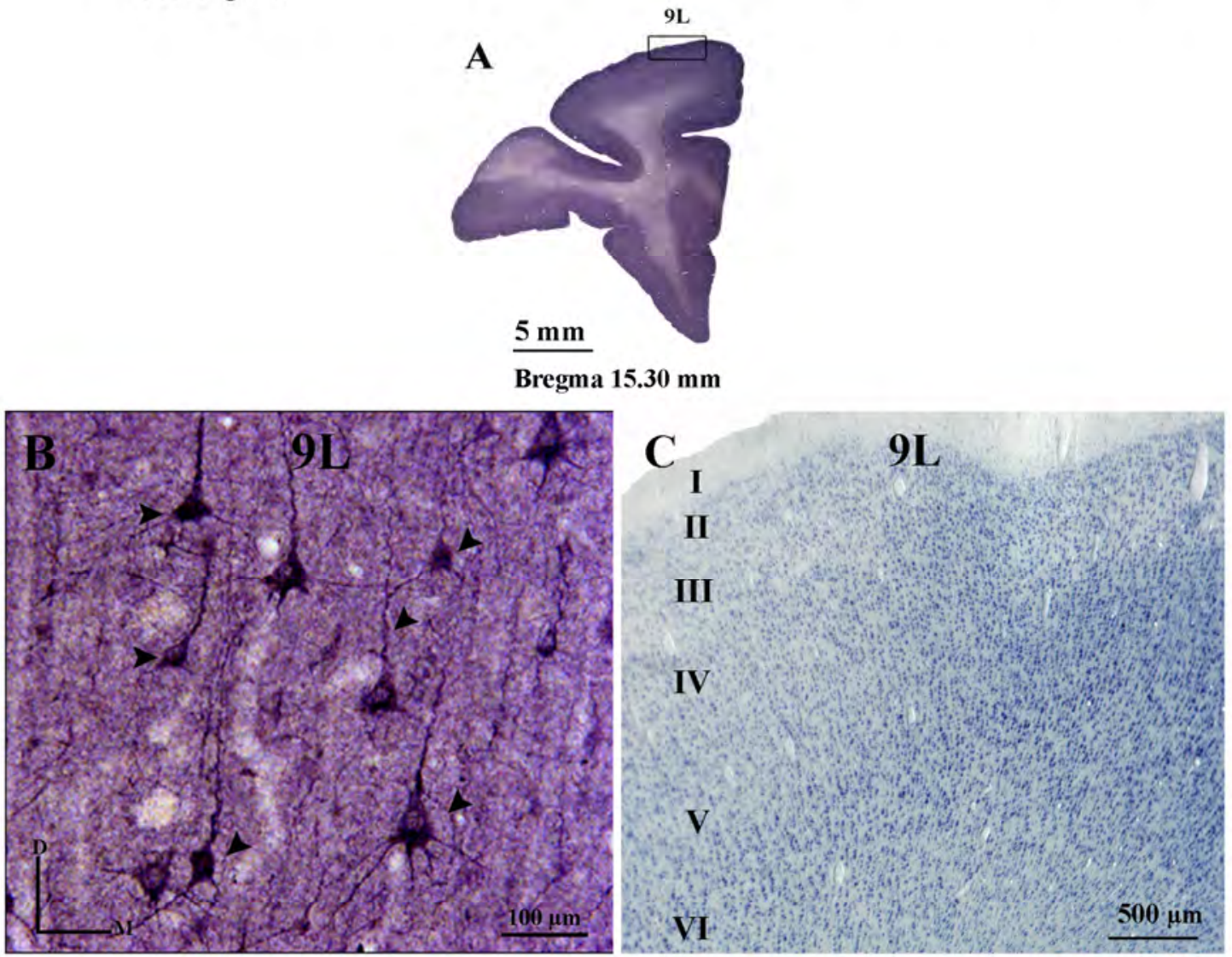

D

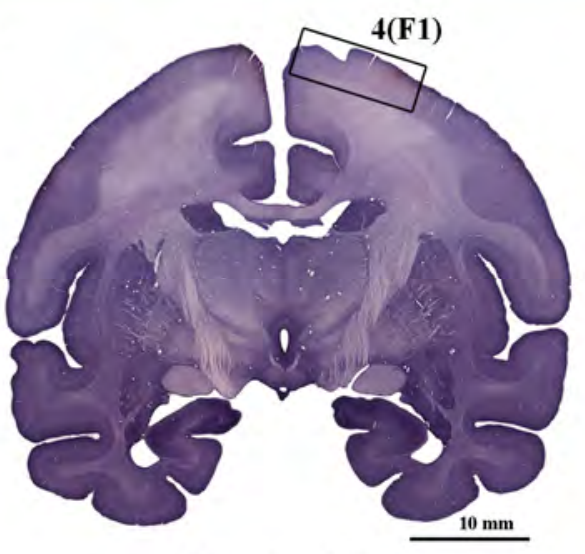

Bregma - $-07.20 \mathrm{~mm}$

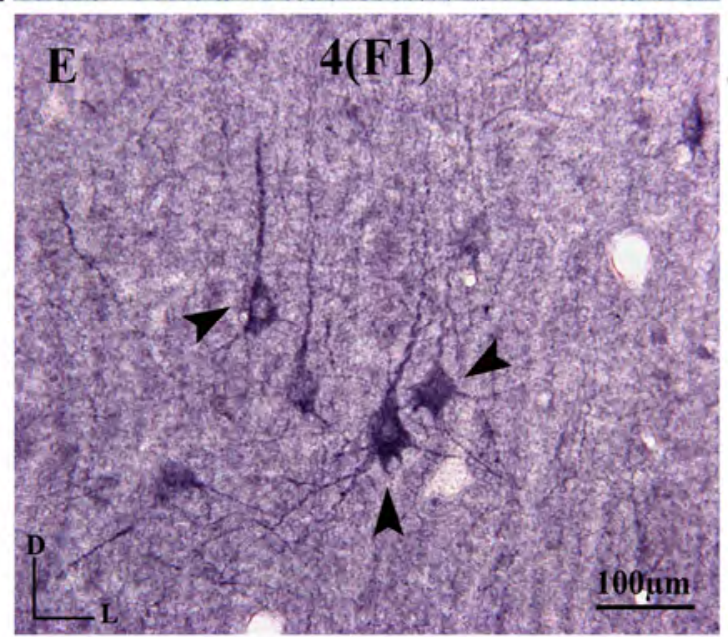

LEGENDA: Fotomicrografias em campo claro evidenciando algumas regiões imunorreativas (imagens B e E). As imagens A e D são imagens macroscópica do córlex pré-frontal e do córtex motor primário. respectivamente, que auxiliam na localizaçâo das regiōes imunomarcadas $\mathrm{B}$ : corpos neuronais TCAP-1-ir na camada III e IV da área 9L do córtex pré-frontal, cabeças de setas. C corte histológico do córtex pré-frontal corado pelo método de nissl (tionina $0.25 \%$ ) auxilia na localização citoarquitetônica das camadas que constituem este cortex. E: corpos neuronais TCAP-1-ir na camada de células piramidais da área 4 (F1) do contex motor primário, cabeças de setas. Abreviaturas- $4(\mathrm{~F} 1)$. área $4(\mathrm{~F} 1)$ do córtes molór primário: $9 \mathrm{~L}$, área 9 do córtex parte lateral; D, dorsal L, lateral.

FONTE: Torres, KR (2012). 
Figura 11- Distribuição dos neurônios TCAP-1 imunorreativos em regiões telencefálica e diencefálica do Cebus apella.

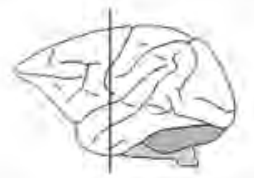

Bregma $-07.20 \mathrm{~mm}$
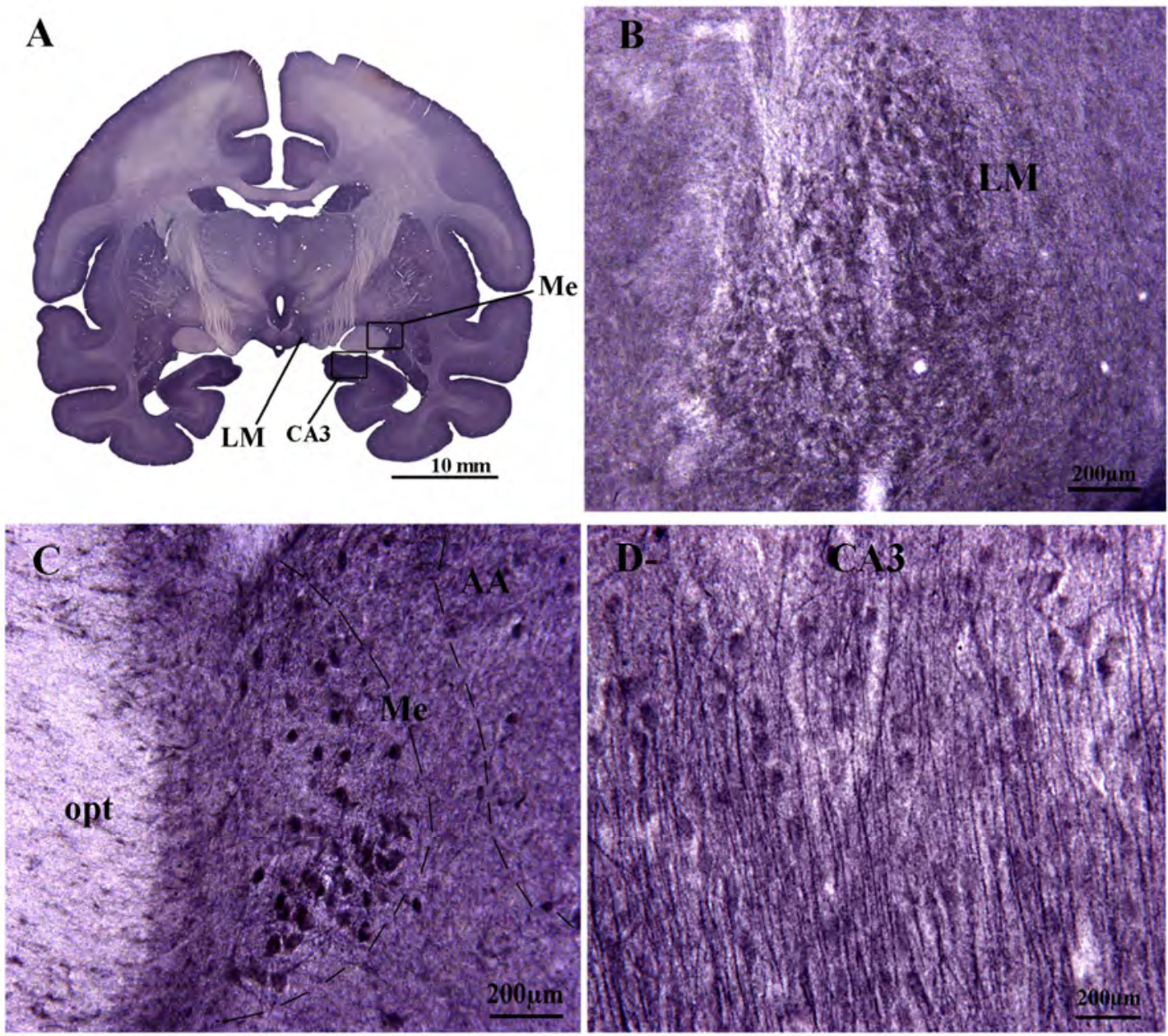

LEGENDA:Fotomicrografias em campo claro mostrando neurônios TCAP-1 imunorreativos em regiões telencefálicas e diencefálica do Cebus apella. Em (A) imagem macroscópica do encéfalo para localização das regiões imunomarcadas. As imagens em (B, C e D) mostram corpos neuronais TCAP1-ir no núcleo mamilar lateral (LM), núcleo medial da amigdala (Me) e na área amigdalóide anterior (AA) e camada CA3 do hipocampo, respectivamente. Abreviaturas: $\mathrm{AA}$, área amigdalóide anterior; CA3, camada $\mathrm{CA} 3$ do hipocampo; D, dorsal; L, lateral; Me, núcleo medial da amigdala; LM, núcleo mamilar lateral; opt, trato óptico. Coordenadas do bregma $-07.20 \mathrm{~mm}$ de acordo com Paxinos, 2009Atlas the Rhesus Brain Monkey.

FONTE: Torres, KR (2012). 
Figura 12 - Imunorreatividade e expressão do RNAm para TCAP-1 no núcleo horizontal da banda diagonal (HDB),

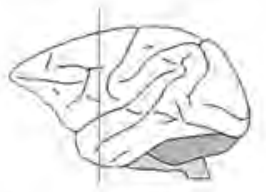

Bregma -04.05 mm
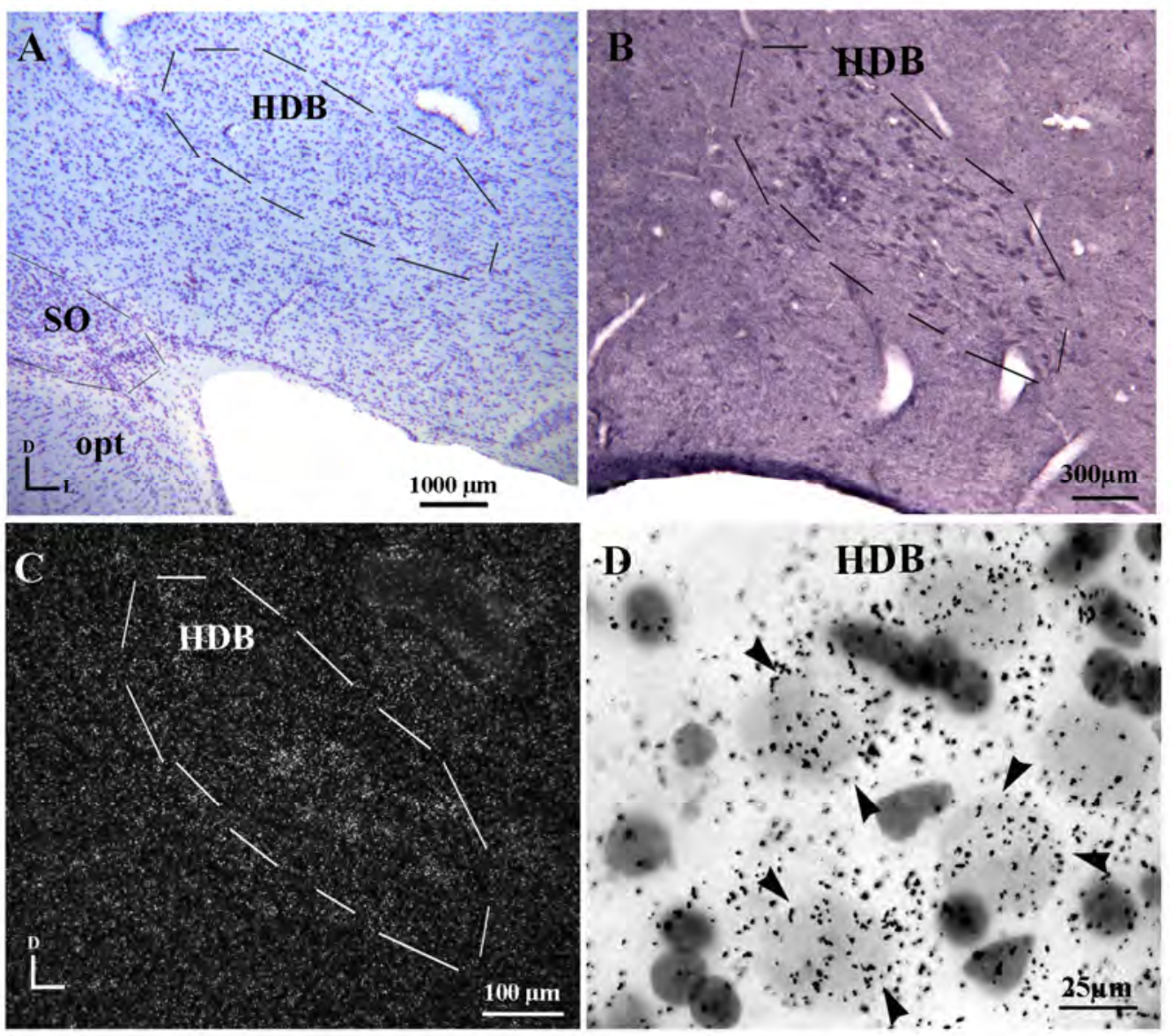

LEGENDA: Fotomicrografias em campo claro (B e D) e campo escuro (C) mostrando o núcleo horizontal da banda diagonal (HDB) com corpos neuronais imunorreativos para TCAP-1 (imagem B) e com déposito de grânulos de prata decorrentes da hibridização com sonda do RNAm para TCAP-1 (imagem C e D - cabeças de setas). Em (A) fotomicrografia em campo claro do corte histológico corado pela técnica de nissl (tionina $0.25 \%$ ) para auxiliar na localização neuroanatômica do HDB. Coordenadas do bregma -04.05 mm de acordo com Paxinos, 2009 - Atlas The Rhesus Brain Monkey.

FONTE: Torres, KR (2012). 
Figura 13 - Imunorreatividade e expressão do RNAm para TCAP-1 no núcleo geniculado lateral dorsal (DLG).

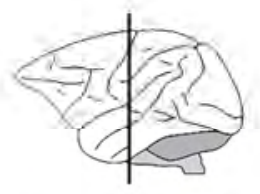

Bregma $-12.60 \mathrm{~mm}$
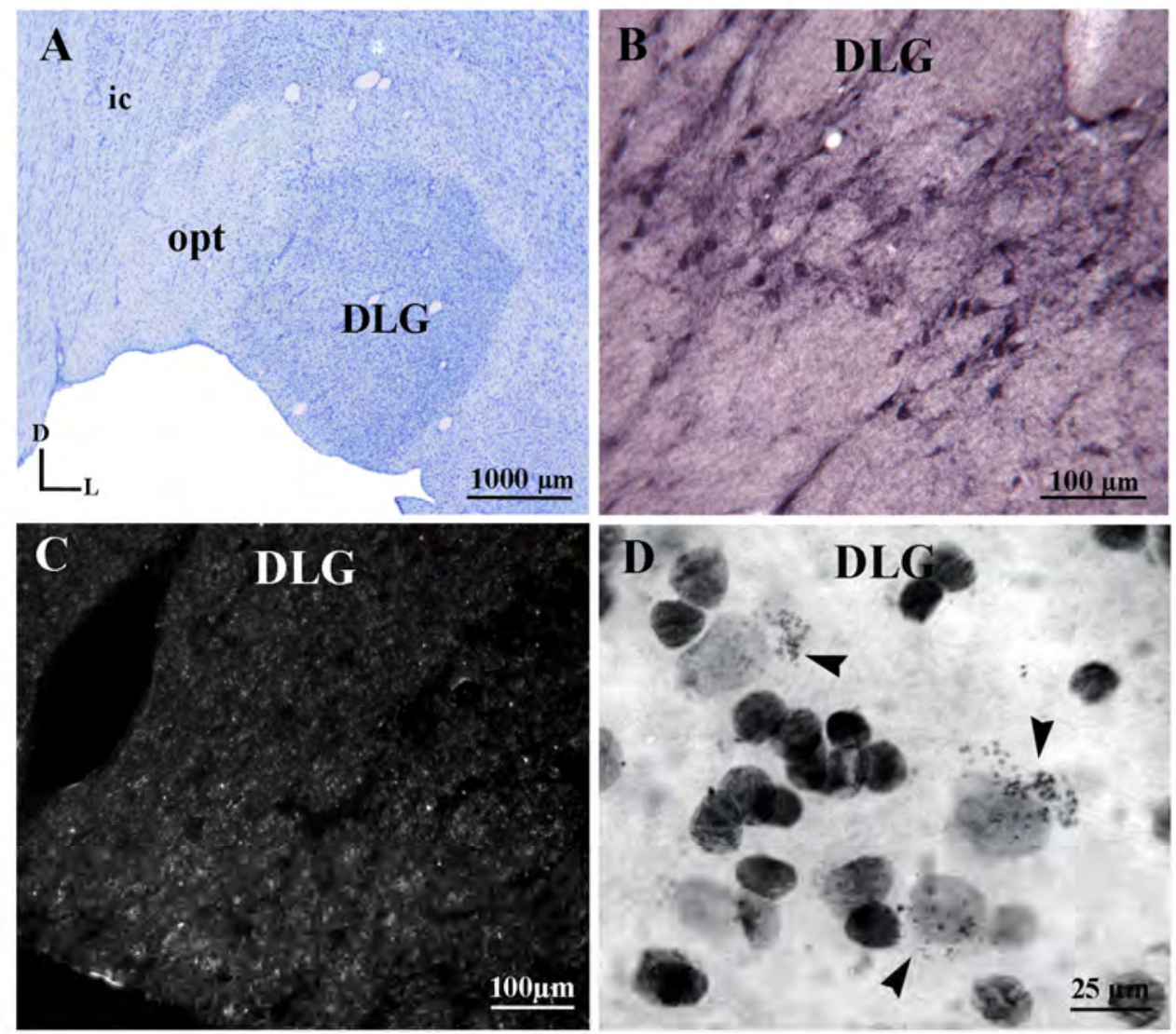

LEGENDA: Fotomicrografias em campo claro (B e D) e campo escuro (C) mostrando o núcleo geniculado lateral dorsal (DLG) com corpos neuronais imunorreativos para TCAP-1 (imagem B) e com déposito de grânulos de prata decorrentes da hibridização com sonda do RNAm para TCAP-1 (imagem C e D - cabeças de setas). Em (A) fotomicrografia $\mathrm{cm}$ campo claro do cortc histológico corado pela técnica de Nisst (tionina $0,25 \%$ ) para auxiliar na localização neuroanatốmica do DLG. Abreviaturas- D. dorsal: DLG, núcleo geniculado lateral dorsal ic. cápsula interna. opt, trato óptico. Coordenadas do bregma $-12.60 \mathrm{~mm}$ de acordo com Paxinos, 2009 - Atlas The Rliesus Brain Monkey.

FONTE: Torres, KR (2012). 
Figura 14 - Imunorreatividade e expressāo do RNAm para TCAP-1 no núcleo supra-óptico (SO).

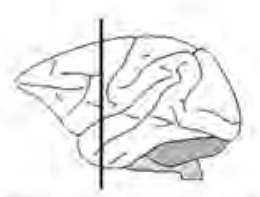

Bregma -04.50 $\mathrm{mm}$
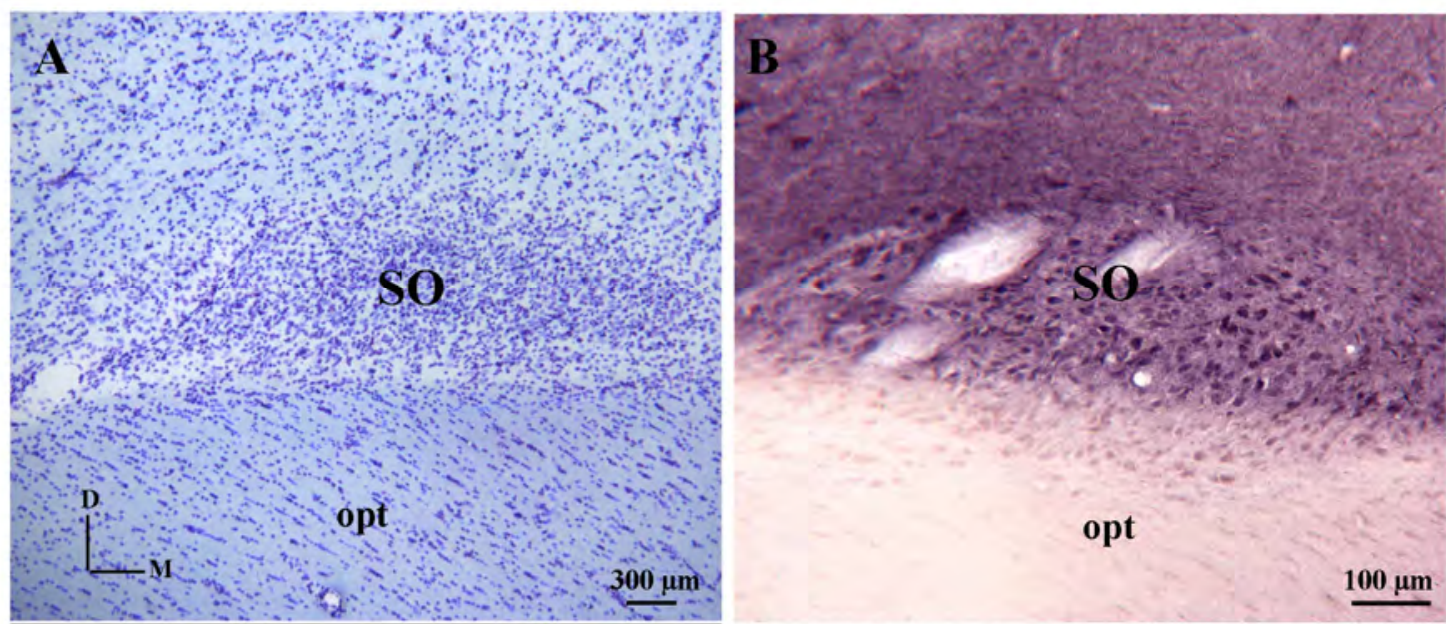

opt

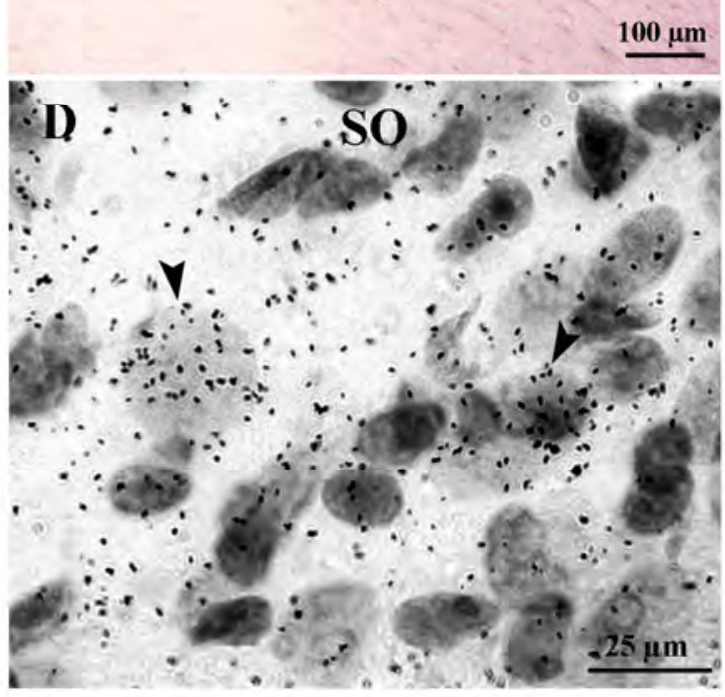

LEGENDA: Fotomicrografias em campo claro (B e D) e campo escuro (C) mostrando o núcleo supra-óptico (SO) com corpos neuronais imunorreativos para TCAP-1 (imagem B) e com déposito de grânulos de prata decoirentes da hibridização com sonda do RNAm para TCAP-1 (imagem C e D - cabeças de setas). En (A) fotomicrografia em campo claro do corte histológico corado pela técnica de Nissl (tionina $0,25 \%$ ) para auxiliar na localização neuroanatômica do SO. Abreviaturas: D, dorsal; $\mathrm{M}$, medial; SO, núcleo supra-óptico; opt, trato óptico. Coordenadas do bregma -04.50 mm de acordo com Paxinos, 20()9 - Atlas The Rhesus Brain Monkey.

FONTE: Torres, KR (2012), 
Figura 15 - Distribuição dos neurônios TCAP-1 imunorreativos em regiões do tronco encefálico do Cebus apella.
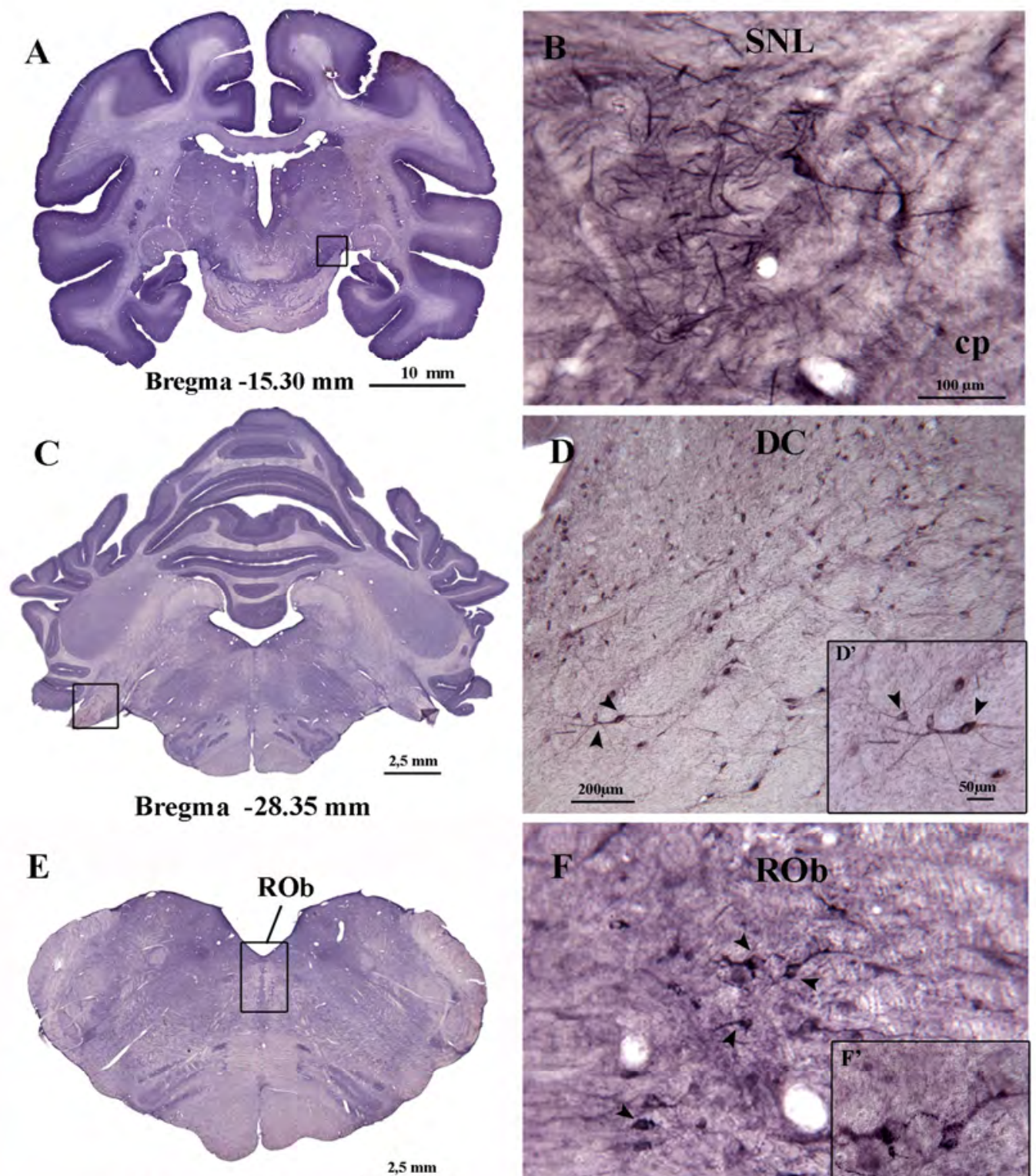

Bregma - $30.15 \mathrm{~mm}$

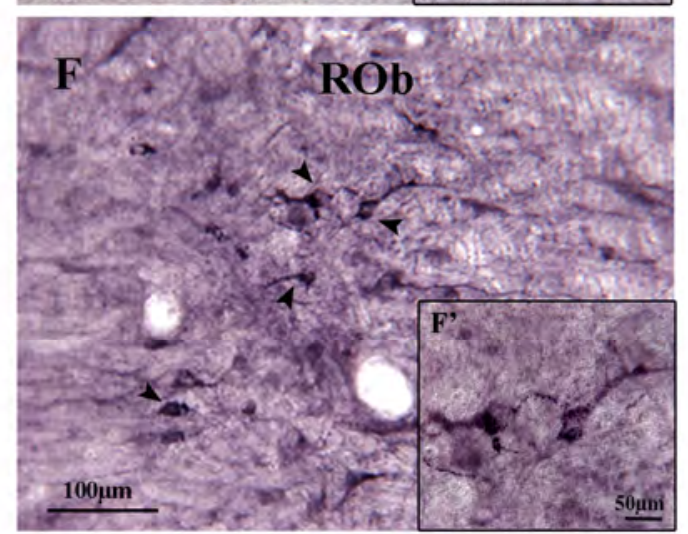

LEGENDA: Fotomicrografias en campo claro (B, D/D' e F/F' evidenciando neurônios TCAP-1 imunorreativos (TCAP-1-ir) no tronco encefálico do Cebus apella. As imagens macroscópicas de regiōes do tronco encéfalico (A. C c E) auxiliam na localização dos neurōnios TCAP-1-ir. Em (B. D/ D' e F/F') evidencia-se as células e prolongamentos neuronais TCAP-1-ir na substância negra, parte lateral (SNL), no núcleo coclear dorsal (DC) e no núcleo obscuró da rafe (ROb). respectivannente. Coordenadas do bregma de acordo com Paxinos, 2009 - Allas The Rhesus Brain Monkey.

FONTE: Torres, KR (2012). 
Figura 16 - Imunorreatividade e expressão do RNAm para TCAP-1 na substância negra, parte reticular (SNR),

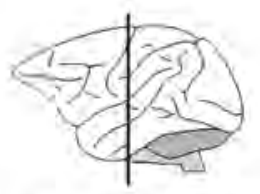

Bregma $-12,60 \mathrm{~mm}$

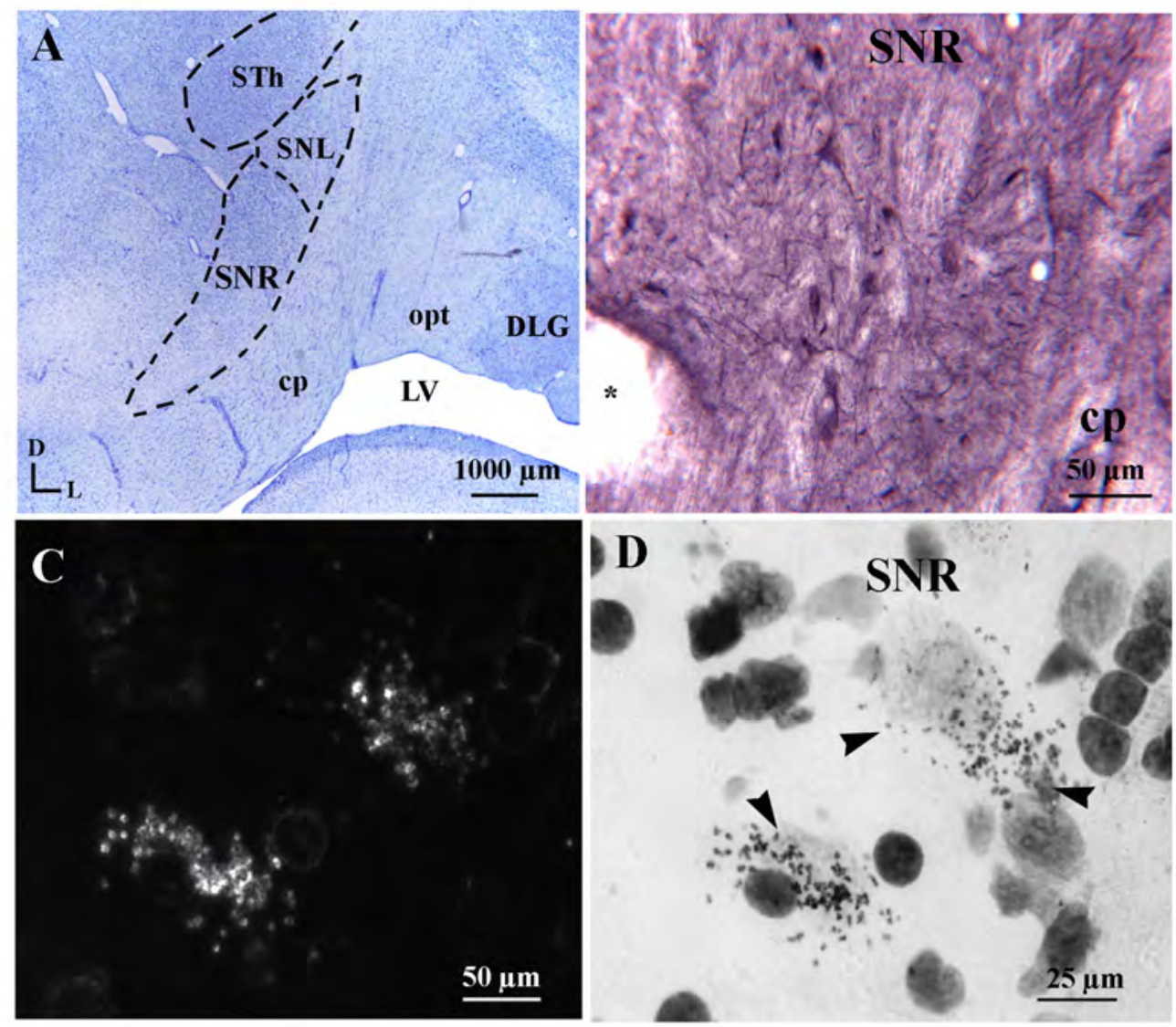

LEGENDA: Fotomicrografias em campo claro (B e D) e campo escuro (C) mostrando a substancia negra, parte reticular (SNR) com corpos neuronais imunorreativos para TCAP-1 (imagem B) e com déposito de grânulos de prata decorrentes da hibridização com sonda do RNAm para TCAP-1 (imagem C e D- cabeças de setas). Em (A) fotomicrografia em campo claro do corte histologico corado pela técnica de Nissl (tionina $0,25 \%$ ) para auxiliar na localização neuroanatómica do SNR $\left({ }^{*}\right)$ artefato do tecido. Coordenadas do bregma $-12.60 \mathrm{~mm}$ de acordo com Paxinos, 2009 - Atlas The Rhesus Brain Monkey.

FONTE: Torres, KR (2012). 
Figura 17 - Distribuiço dos neuronios TCAV-1 imumorreativos en regibes do cerebelo do Cebus ajpel/a.
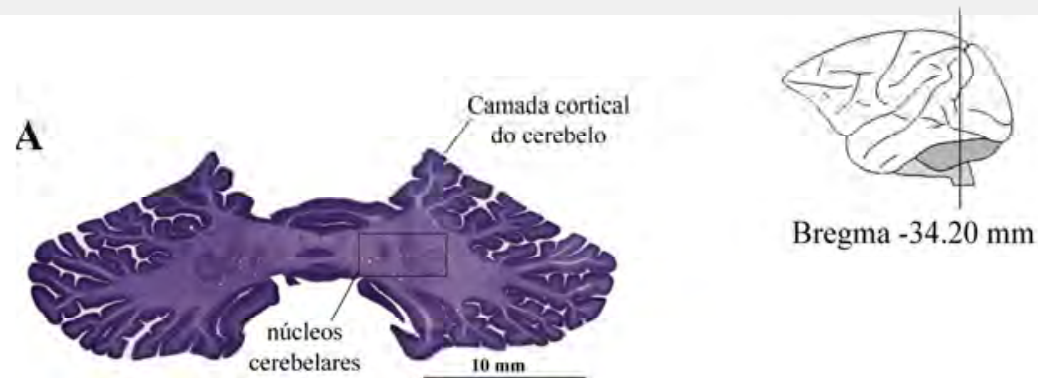

Bregma $-34.20 \mathrm{~mm}$
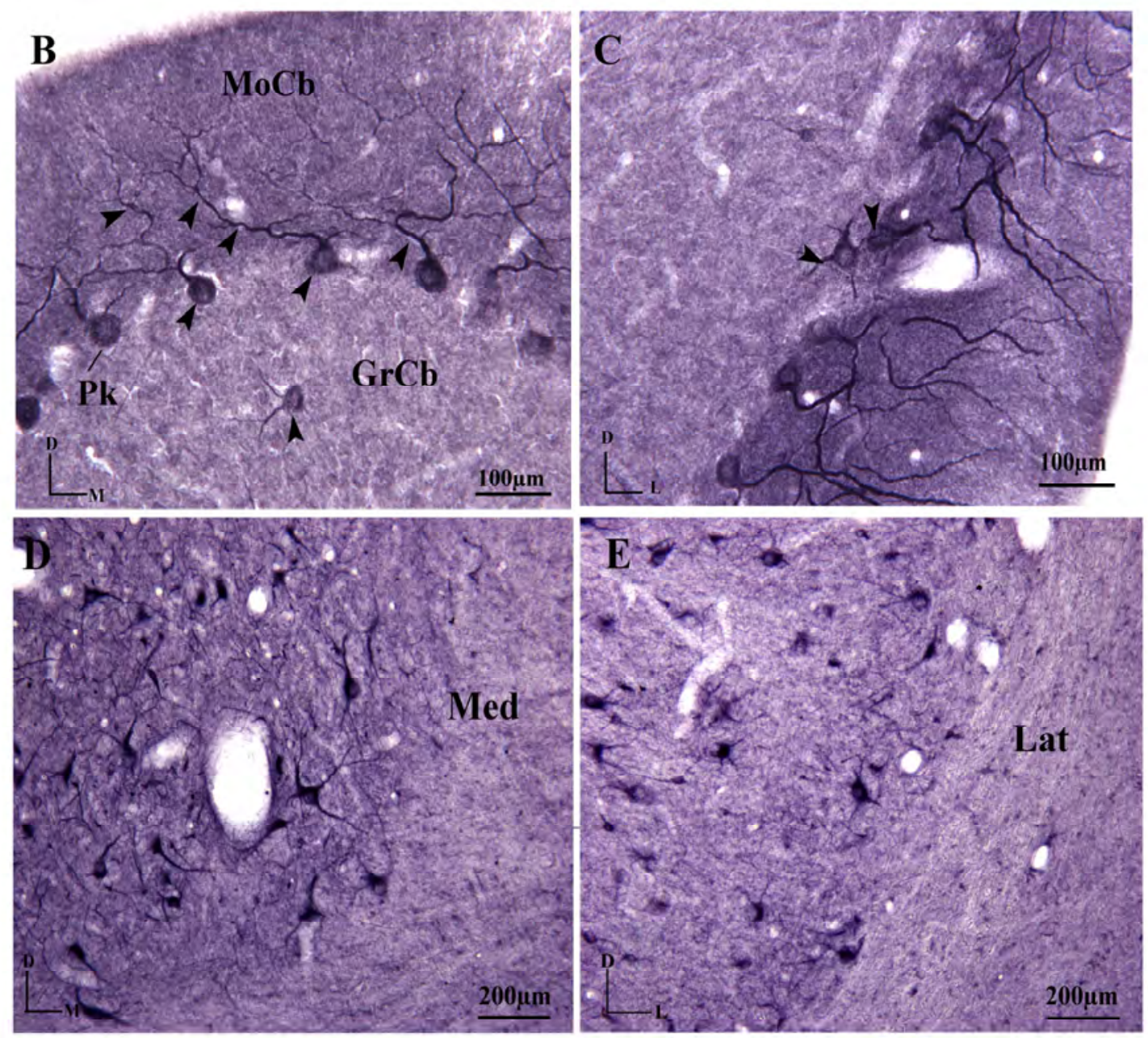

LEGENDA: Fotomicrografias em campo claro mostrando neurônios TCAP-1 imunorreativos na região cortical e dos núcleos do cerebelo do Cébus apella. (A) Imagem macroscópica do cerébelo para localização das regiōes do cótex e núcleos cerebelares imuomarcadus. As inagen (B e C) mostram corpos ueuronais TCAP-1-ir na canada de Purkinge do cerebolo (PR) e aa camada geamular do cerebelo (GrCb), cabeças de setas. Nas imagens (D e E) notam-se corpos neuronais TCAP-1-ir no núcleo cerebelar medial (Med) e nucleo lateral do cerebelo (Lat). Abreviaturas: D, dorsal: GrCb. camada granular do cerebelo; L, lateral; Lat, núcleo lateral do cerebelo; M, medial; Med, núcleo cerebelar medial: Mocb caunada molecular do cerebelo: Pk, canada de Purkinje do cerebelo. Cacrienadas do bregma -34.20 stm de acordo com Paxinos, 2009 - Adlas The Rhesus Brain Monkey,

FONTE: Torres, KR (2012). 
Figura 18 - Desenho representativo da distribuição do TCAP-1 em algumas regiões do sistema nervoso central (SNC) do Cebus apella.

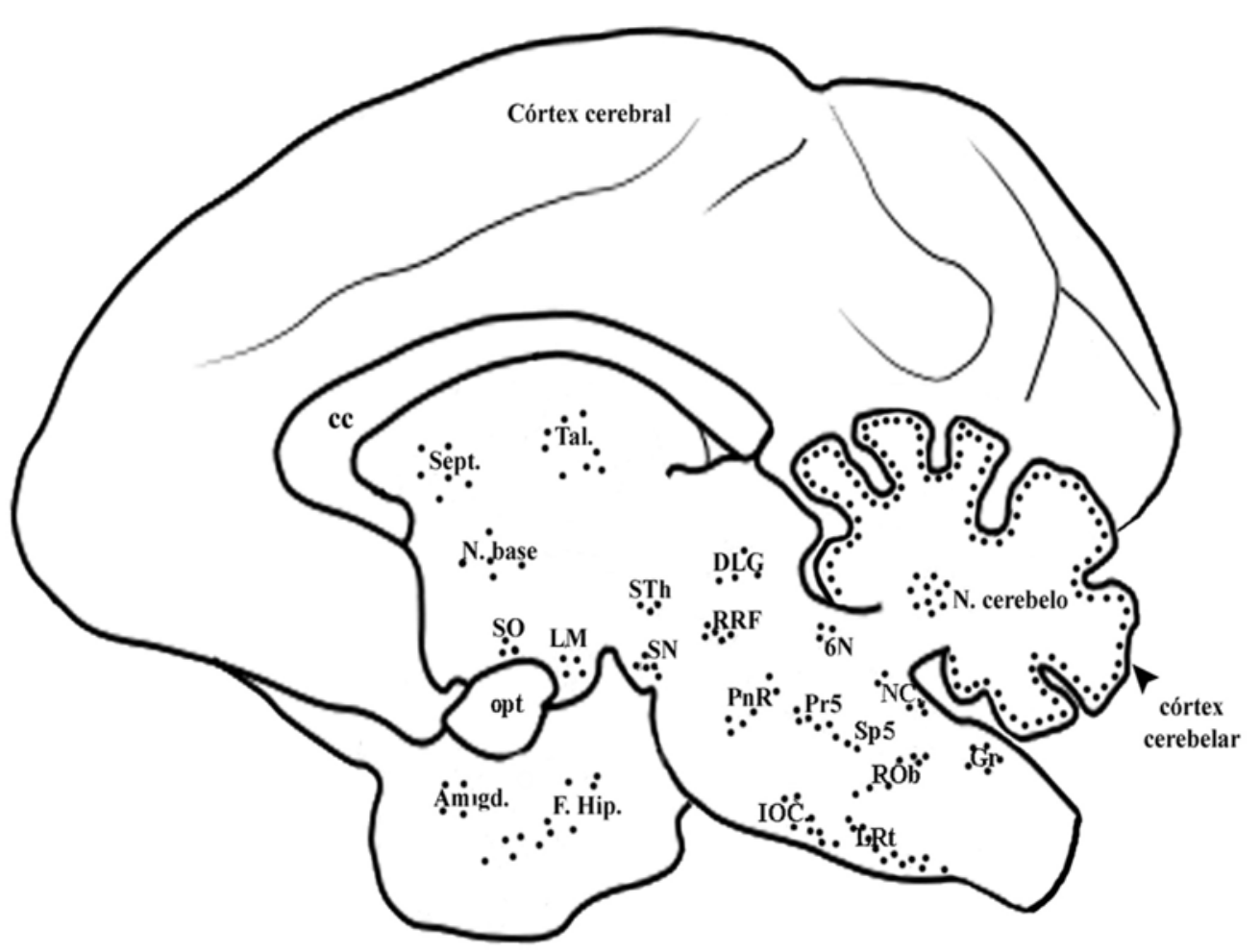

LEGENDA: Vista medial de um corte sagital do SNC do Cebus apella com os corpos neuronais imunorreativos para TCAP-1 (TCAP-1-ir) representados pelos pontos. Abreviaturas: $6 \mathrm{~N}$, núcleo do nervo abducente; Amígd., amígdala; cc, corpo caloso; DLG, núcleo geniculado lateral dorsal; F. Hip., formação hipocampal; Gr, núcleo grácil; IOC., complexo olivar inferior; LM, núcleo mamilar lateral; LRt, núcleo reticular lateral; N. base, núcleos da base; N. cerebelo, núcleos do cerebelo; NC, núcleos cocleares; opt, trato óptico; PnR, núcleo pontino da rafe; Pr5, núcleo principal do trigêmio; ROb, núcleo obscuro da rafe; RRF, campo retrorubral; Sept., área septal; SN, substância negra; SO, núcleo supra-óptico; Sp5, núcleo espinal do trigêmio; STh, núcleo subtalâmico; Tal., núcleos talâmicos.

FONTE: Torres, KR (2012). 


\subsection{Distribuição do TCAP-1 e TEN 1 no SNC do Cebus apella}

A análise dos resultados das reações de imunoperoxidase e de dupla imunofluorescência demonstrou algumas diferenças principalmente no que se refere ao padrão de marcação das células neuronais TEN 1-ir e TCAP-1-ir. O resultado para TEN 1 sugere um padrão de imunorreatividade concentrada na periferia do corpo neuronal, ou seja nas proximidades da membrana plasmática, enquanto que TCAP-1 apresenta-se amplamente difuso no citosol das células neuronais (figura 19). Este padrão de imunorreatividade para TCAP-1 foi verificado em todas as regiões encefálicas descritas acima. O padrão para TEN 1 foi bem característico em algumas regiões do SNC como tronco encefálico e cerebelo.

Quanto à localização da imunorreatividade foi notado que TCAP-1 encontra-se amplamente distribuído em todas as regiões encefálicas sendo verificada em muitas destas regiões correspondência com a distribuição da TEN 1. A imunorreatividade para TEN 1 foi encontrada em núcleos da região telencefálica como núcleo horizontal da banda diagonal (HDB), globo pálido interno (IGP), núcleo medial da amígdala (Me) e área amigdalóide anterior (AA) e na formação hipocampal, mais especificamente nas camadas CA1-CA3. Com exceção do núcleo subtalâmico (STh) e núcleo geniculado lateral dorsal (DLG) não foi verificado imunorreatividade para TEN 1nas demais regiões diencefálicas. No tronco encefálico verificamos neurônios TEN 1-ir na substância negra reticular e lateral (SNR e SNL), no núcleo coclear dorsal (DC), núcleo reticular lateral (LRt) e núcleo reticular gigantocelular . Na camada cortical do cerebelo, camada de células de Purkinje (Pk), e nos núcleos do cerebelo foi verificado neurônios TEN-1-ir. 
Figura 19 - Padrão de imunorreatividade e co-localização da TEN 1 e TCAP-1.
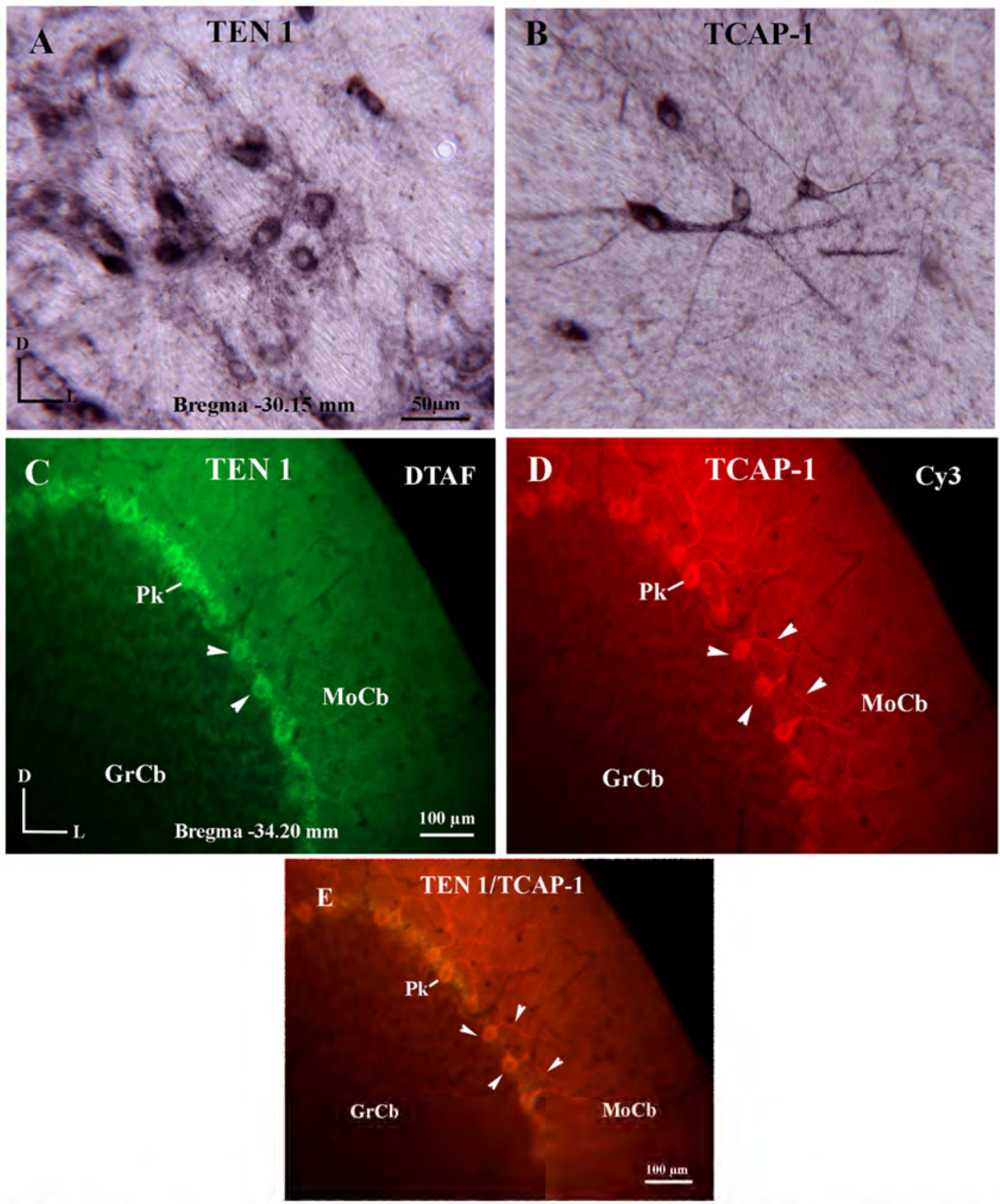

LEGENDA:Fotomicrografias em campo claro (A e B) e em epifluorescência (C,D e E) mostrando o padrão de imunomarcação dos neurônios TEN 1 imunorreativos (TEN 1-ir) e TCAP-1 imunorreativos (TCAP1-ir). As imagens (A) e (B) do núcleo coclear dorsal (DC) e (C), (D) e (E) da camada de Purkinje do cerebelo $(\mathrm{Pk})$, respectivamente, evidenciam o padrão de marcação da TEN 1 e do TCAP-1. As imagens $(A)$ e $(C)$ evidenciam o padrão de marcação da TEN 1 que se apresentam próximo da membrana plasmática. As imagens (B) e (D) evidenciam padrão de marcação para TCAP-1 que se apresenta difuso pelo corpo e prolongamentos celulares. A imagem (E) sobreposição das imagens (C) e (D) mostra a co-localização da TEN 1 e TCAP-I no corpo neuroal. Abreviaturas: D. dorsal; DC. mícleo coclear dorsal; $\mathrm{GrCb}$, camada granular do cerebelo; $\mathrm{L}$, Jateral; $\mathrm{MoCb}$, camada molecular do cerebelo; Pk, camada de Purkinje do cerebelo. Coordenadas do bregma de acordo com Paxinos. 2009 - Atlas The Rhesus Brain Monkey.

FONTE: Torres, KR (2012). 


\subsection{Considerações sobre o controle da técnica de imuno-histoquímica}

O uso da técnica de imuno-histoquímica é uma valiosa ferramenta para localização de proteínas ou outras moléculas em tecidos e cultura de células, sendo utilizado tanto em pesquisas científicas quanto em exames de diagnóstico. $\mathrm{O}$ uso desta técnica foi descrita inicialmente no ano 1942 por Coons, et al. (1942) para localização de pneumococos no fígado. A partir desta data iniciou-se ampla utilização da técnica de imuno-histoquímica acompanhada pela busca de procedimentos controles da mesma, uma vez que, um dos elementos cruciais deste procedimento é garantir a especificidade do anticorpo primário no reconhecimento do seu antígeno e assim assegurar a convincente relação entre produto da reação e o antígeno (Burry, 2011). Além da realização de todas as etapas da técnica de imuno-histoquímica outros procedimentos controles garantem determinar a especificidade da técnica como o controle do anticorpo primário e do anticorpo secundário (Holmseth, Lehre e Danbolt, 2006; Burry, 2011).

O controle do anticorpo primário se baseia na determinação da concentração ideal do anticorpo primário (teste de titulação) e na determinação da especificidade do anticorpo primário através da adsorção com seu antígeno (teste de adsorção). A titulação permite assegurar uma adequada concentração do anticorpo primário, impedindo que o excesso ou a insuficiente quantidade deste resulte em marcações falso-negativo ou falsopositivo (Hoffman, Le e Sita, 2008). Assim sendo, foi estabelecido que as concentrações ideais dos anticorpos anti-TCAP-1 e anti-TEN1 foram de 1:1700 e 1:500, respectivamente, em virtude da convincente e uniforme imunomarcação nos corpos neuronais e reduzida/ausente marcação de fundo, conforme estabelecido por Hoffman et al. (2008) quando se utiliza o teste de titulação para determinar a concentração ideal do anticorpo primário na técnica de imuno-histoquímica.

$\mathrm{Na}$ adsorção a concentração fixa do anticorpo primário é previamente adsorvido com concentrações crescentes do seu antígeno, sendo notada, a ausência de ligação do anticorpo primário pré adsorvido no antígeno tecidual devido à saturação dos seus sítios de ligação (Saper e Sawchenko, 2003). Este padrão foi observado no teste de adsorção para TCAP-1 o qual resultou na ausência completa de imunorreatividade, nas maiores 
concentrações do peptídeo TCAP-1, demonstrando uma nítida especificidade do anticorpo primário no reconhecimento do seu antígeno.

O segundo controle proposto para técnica de imuno-histoquímica é referente ao anticorpo secundário que é realizado através da incubação do tecido com as soluções empregadas na técnica, incluindo anticorpo secundário, porém sem a incubação prévia no anticorpo primário. Isto auxilia na confirmação de que a imunorreatividade é oriunda da ligação do anticorpo secundário no anticorpo primário (Burry, 2011). Neste projeto a omissão do anticorpo primário tanto para TCAP-1 quanto para TEN 1 não resultou em imunomarcações, eliminado a possibilidade de reação cruzada do anticorpo secundário, complexo avidina-biotina e do cromógeno com constituintes teciduais.

\subsection{Considerações sobre o padrão de marcação}

Os resultados advindos da técnica de imuno-histoquímica para TEN 1 e de dupla imunofluorescência para TEN 1 e TCAP-1 evidenciam que a imunorreatividade para TEN 1 apresenta-se concentrada principalmente próxima a membrana plasmática na região do corpo neuronal. Este padrão de imunorreatividade para a TEN 1 também foi constatado em estudos feito em aves, artrópodes, roedores e nematelmintos (Caenorhabditis elegans), sendo sugestivo de uma proteína transmembrana (Levine et al., 1994; Levine, Weiss e Wides, 1997; Oohashi et al., 1999; Rubin et al., 1999; Drabikowski, Trzebiatowska e Chiquet-Ehrismann, 2005). O padrão de marcação para TCAP-1 mostra-se diferente da TEN 1; estando a imunorreatividade do TCAP-1 difusamente distribuído no citosol celular coincidindo com o padrão verificado por Chand, 2011 (em fase de elaboração) ${ }^{2}$.

\subsection{Considerações sobre a especificidade da sonda}

A sonda utilizada na técnica de hibridização foi desenhada para detectar o RNAm para TCAP-1 presente no SNC do Cebus apella. Assim, através da análise de

\footnotetext{
${ }^{2}$ Chand D, Al Chawaf A, Tan LA, Ng T, Casatti C, Song L, Kollara A, Brown T, Rotzinger S, Belsham DD, Boutros P, Vaccarino FJ, Barsyte-Lovejoy D, Lovejoy DA. C-terminal region of teneurin-1 in mouse hippocampus: Cellular and tissue locations, binding site and regulation of dendritic arborization. Journal of Neuroscience.
} 
identidade foi possível verificar que a porção gênica da sonda reconhece o RNAm para TCAP-1 do Cebus apella e mostra-se conservada entre as espécies, apresentando elevada identidade entre as sequências gênicas do TCAP-1 de primatas não humanos e humanos. Estes resultados reforçam especificidade da sonda utilizada para TCAP-1 tanto para a espécie Cebus apella quando para o RNAm do TCAP-1. Estas considerações colaboram com os dados da literatura que analisaram e/ou discutiram o sistema peptidérgico TCAP-1/TEN1 e o descreveram como um sistema preservado entre artrópodes, aves, roedores e humanos e com maior grau de identidade em espécies filogeneticamente evoluídas. (Baumgartner e ChiquetEhrismann 1993; Baumgartner et al., 1994; Levine et al., 1994; Minet et al., 1999; Rubin et al., 1999; Minet e Chiquet-Ehrismann, 2000; Fascetti e Baumgartner, 2002; Oohashi et al., 1999; Zhou et al., 2003; Wang et al., 2005; Kenzelmann et al., 2008; Lovejoy, Rotzinger e Lovejoy-Barsyte, 2009a).

\subsection{Considerações comparativas: neuroanatômicas e funcionais do TCAP-1 em roedores e primatas não-humanos (Cebus apella)}

Os resultados do presente trabalho são os primeiros a detalhar a distribuição do sistema peptidérgico TCAP-1/TEN 1 no SNC de primata não-humano adulto Cebus apella, uma vez que, dados na literatura descreveram a preservação deste sistema ao longo das espécies porém não realizaram mapeamento sistematizado em seu principal sítio de distribuiç̧ão que é o SNC.

A descrição de uma nova família de peptídeos bioativos oriundos do terminal carboxila das teneurinas (TCAPs) ocorreu em estudos preliminares que buscavam a descoberta de peptídeos que apresentassem homologia ao CRF, que é um importante neuropeptídeo regulador das respostas comportamentais, neuroendócrinas e autônomicas do estresse (Rotzinger, Lovejoy e Tan, 2010; Qian et al., 2004). Nesses estudos foi constatado que a porção carboxi-terminal de todas as proteínas teneurinas apresentavam elevada identidade com a família do CRF e exibiam sítios de clivagem que poderia resultar na liberação de um peptídeo, o qual denominaram de TCAPs (Teneurin C-Terminal Associated Peptide) (Qian et al., 2004; Lovejoy et al., 2006a, 2006b). Foram descritos a existência de quatro TCAPs (TCAP-1 a 4) que estão associados a respectiva proteína teneurina (teneurina 1 a 4), sendo que TCAP-1 e TEN 1 são mais abundantes no SNC e seus papéis funcionais tem 
sido gradativamente descritos principalmente para o TCAP-1 (Lovejoy, Al Chawaf e Cadinouche, 2006a; Trubiani et al., 2007; Tan et al., 2008; Lovejoy, Rotzinger e LovejoyBarsyte, 2009a).

Estudos funcionais foram os primeiros a serem realizados para verificar o papel do peptídeo TCAP-1 em culturas de células hipotalâmicas e hipocampais (in vitro) e no comportamento emocional (in vivo). Foi verificado in vitro, que a versão sintética do TCAP1 é capaz de desempenhar várias funções bioativas como regulação do crescimento dos neuritos e das proteínas do citoesqueleto (Al Chawaf et al., 2007a), aumentar os níveis de AMPc e proliferação celular em cultura de neurônios imortais quando aplicado em baixas concentrações (Wang et al., 2005); além de um papel neuroprotetor após estresse celular induzido por alteração de pH (Trubiani et al., 2007).

Estudos in vivo que utilizaram de testes comportamentais como o teste de sobressalto acústico foram importantes para avaliar o potencial efeito de fármacos no controle de estados de depressão e ansiedade. Animais que são naturalmente ansiosos/depressivos ou que são expostos ou induzidos a tal situações apresentam maior sensibilidade ao estímulo acústico diminuindo o limiar para a resposta reflexa de sobressalto (Rotzinger, Lovejoy e Tan, 2010). Diante disto, foi verificado que a administração aguda i.c.v. de TCAP-1 no núcleo basolateral da amígdala de ratos foi capaz de induzir mudanças ao teste de sobressalto. Animais que, previamente ao teste de sobressalto, são naturalmente ansiosos apresentaram redução na resposta de sobressalto após essa administração do TCAP-1 no núcleo basolateral da amígdala (Wang et al., 2005). Animais exibindo quadro de ansiedade induzido pela administração i.c.v. de CRF apresentaram redução na resposta de ansiedade, após a administração crônica de TCAP-1 i.c.v, sugerindo que o peptídeo TCAP-1 interage com CRF promovendo efeito ansiolítico (Tan et al., 2008). Assim, foi notado que administrações de TCAP-1 no SNC mostraram-se efetivas para controlar estados ansiogênicos, confirmado por meio de testes comportamentais. Outra via de administração desse peptídeo, como a intravenosa, também mostrou-se eficaz na redução da ansiedade induzida por injeções de CRF i.c.v (Al Chawaf et al., 2007b). Estes resultados sugerem que o TCAP-1 apresenta adequada bioatividade e biodisponibilidade, imprescindíveis para futuras aplicações desse peptídeo como um fármaco ansiolítico (Lovejoy, comunicação pessoal) ${ }^{3}$.

\footnotetext{
${ }^{3}$ Lovejoy DA. Universidade de Toronto, Canadá, 2011.
} 
A distribuição do TCAP-1 no SNC até o momento foi realizada em roedores por Wang e colaboradores em 2005 e os resultados de distribuição na região hipocampal de camundongos e ratos foi confirmado por Chand, 2011 (em fase de elaboração) ${ }^{4}$. Wang e colaboradores (2005) identificaram que o RNAm para TCAP-1 encontra-se em regiões do SNC de roedores que estão associadas com a regulação da emoção, ansiedade e motivação como camadas CA1, 2 e 3 do hipocampo, giro denteado da formação hipocampal, córtex piriforme e núcleo central e basolateral da amígdala. Outras regiões encefálicas descritas por estes autores foram a camada de células de Purkinje do cerebelo, bulbo olfatório, núcleo ventromedial do hipotálamo, núcleo subtalâmico, núcleos do nervo vago e hipoglosso.

Os resultados de distribuição neuroanatômica do RNAm para TCAP-1 no Cebus apella apresentou similaridades com o estudo de Wang, et al. (2005). Entretanto, algumas regiões de expressão do RNAm para TCAP-1 no SNC não foram coincidentes entre roedores e primata não-humano tais como giro denteado da formação hipocampal, núcleo basolateral da amígdala, núcleo do nervo hipoglosso e núcleo ventromedial do hipotálamo os quais mostraram expressão no SNC de rato. Entretanto, inúmeras outras regiões apresentaram expressão do RNAm para TCAP-1 no Cebus apella que não foram descritas no encéfalo de ratos. Dentre estas regiões podemos citar resumidamente a presença de RNAm nas camadas III e V do isocórtex, nas áreas amigdalohipocampal, núcleos da base, região septal, região do subículo da formação hipocampal, núcleos talâmicos, núcleos cerebelares e em vários núcleos do tronco encefálico.

Considerando as expressões do RNAm para TCAP-1 no SNC do Cebus apella e do rato, pode ser considerado que este peptídeo mantém-se preservado, principalmente em áreas encefálicas associados com o sistema límbico.

\subsection{Considerações neuroanatômicas e funcionais da distribuição de TCAP-1 em primatas não-humanos (Cebus apella)}

Os resultados deste estudo demonstraram que a distribuição do peptídeo e do RNAm para TCAP-1 encontram-se amplamente distribuídos no encéfalo do Cebus apella e

\footnotetext{
${ }^{4}$ Chand D, Al Chawaf A, Tan LA, Ng T, Casatti C, Song L, Kollara A, Brown T, Rotzinger S, Belsham DD, Boutros P, Vaccarino FJ, Barsyte-Lovejoy D, Lovejoy DA. C-terminal region of teneurin-1 in mouse hippocampus: Cellular and tissue locations, binding site and regulation of dendritic arborization. Journal of Neuroscience.
} 
devido a isto, esta secção buscou estabelecer possíveis correlações funcionais atribuídas tanto ao TCAP-1 quanto a alguns dos territórios encefálicos que apresentaram este peptídeo. Além disso, estudos de distribuição das TENs no SNC tem mostrado que estas se encontram em circuitos internucleares envolvidos em funções específicas sugerindo que estas proteínas participam da interação homofílicas entre os neurônios destes circuitos desde a neurogênese até a fase adulta (Rubin et al., 1999; Oohashi et al., 1999; Rubin et al., 2002; Zhou et al., 2003; Tucker e Chiquet-Ehrismann, 2006; Kenzelmann et al., 2007; Kenzelmann et al., 2008). Devido a isso, é possível que a família de peptídeos TCAPs também possa estar distribuído em circuitos neuronais envolvidos com funções específicas entre elas a da modulação do comportamento emocional. Assim sendo, a discussão que se segue também apresentará alguns circuitos internucleares que expressam simultaneamente TCAP-1 e podem ou não estar envolvidas com a modulação do comportamento emocional.

A imunorreatividade e expressão do RNAm para TCAP-1 no SNC do Cebus apella foi encontrada em regiões neuroanatômicas envolvidas no controle da motricidade como córtex motor primário-área 4(F1), pálido ventral (VP), globo pálido (GP), núcleo subtalâmico (STh) e substância negra (SN). Estudos com administração de TCAP-1 têm mostrado que este peptídeo não altera o comportamento basal em testes como campo aberto e labirinto em cruz elevada, que são testes locomotores de exploração utilizados para avaliar a capacidade ansiolítica ou ansiogênica de novos agentes terapêuticos (Tan et al., 2008; 2009). Porém frente a um agente estressor, como a admiministração i.c.v de CRF, seguida de administração endovenoso de TCAP-1 é notado redução do comportamento ansiogênico induzido pelo CRF nos testes acima citados, demonstrando que TCAP-1 pode estar envolvido na modulação da resposta motora durante situaçãoes estressoras (Al Chawaf et al., 2007). Além disso, outras funções têm sido atribuídas às clássicas regiões de controle da motricidade, tal como o controle da hiperalgesia através da estimulação elétrica do córtex motor primário (Lucas, Ji e Masri, 2011). O mecanismo proposto para esta função é que a área motora 4(F1) apresenta densa projeção para a zona incerta (ZI), que é responsável por mediar a função analgésica em alguns processos nociceptivos (Masri et al 2009). É interessante ressaltar que o 4(F1) e a ZI apresentaram imunorreatividade ao TCAP-1, sendo sugestiva a participação deste peptídeo nesta via de modulação da dor. Outras funções não motoras tem sido descrito para o STh e o VP, tais como controle motivacional, cognitivo e emocional (Le Jeune et al., 2010; Temel, 2010; Turner et al., 2008). A estimulação elétrica no 
STh tem sido muito utilizada como terapia complementar em pacientes com doença de Parkinson para melhorar a habilidade motora porém, muitos pacientes apresentam mudanças comportamentais como depressão e mania (Temel, 2010). Isto talvez se deva a interconexão do STh com áreas motoras e regiões límbicas principalmente no que se refere a sua conexão recíproca com o VP, que é considerado o maior circuito de projeção para áreas límbicas (Haber et al., 1985). Também tem sido verificado que a $\mathrm{SN}$ representa a maior fonte dopaminérgica para o núcleo basolateral da amígdala e a degeneração desta via, que é verificado na porção reticular da substância negra de pacientes com Parkinson, resulta em prejuízos neuronais tanto na execução motora quanto na modulação do humor, acarretando em sintomas de ansiedade (Drevets, Price e Furey, 2008).

Estudos têm verificado que mediadores clássicos do SNC como dopamina, serotonina, noradrenalina e acetilcolina apresentam projeções para o sistema límbico sendo importantes para regulação do humor (Carrasco e Van de Kar, 2003; Drevets, Prince e Furey, 2008). As projeções dopaminérgicas, oriundas principalmente da área tegmental ventral e da parte compacta da substância negra, fazem sinapses na região do córtex pré-frontal, amígdala, formação hipocampal entre outras regiões (Pezze e Feldon, 2004). Os resultados de distribuição de TCAP-1 no Cebus apella demonstram que este peptídeo encontra-se em várias áreas do tronco encefálico, entre elas parte compacta da substância negra e área tegmental ventral, bem como em regiões encefálicas que são alvo de projeções dopaminérgicas como córtex pré-frontal, amígdala e formação hipocampal. Estes resultados colaboram com estudos funcionais que demostraram a participação da via dopaminérgica no comportamento emocional como caracterizado em estudos de medo condicionado na qual é verificado a participação da substância negra na consolidação da memória frente a um estímulo agressivo (Baldi e Bucherelli, 2010; Baldi, Mariottini e Bucherelli, 2007) e em estudos de estimulação elétrica da área tegmental ventral que resultou na excitabilidade do núcleo central da amígdala, ocasionando respostas de medo exagerado (Gelowitz e Kokkinidis, 1999).

O córtex pré-frontal, amígdala e formação hipocampal também são alvo de projeção serotoninérgica oriunda principalmente dos núcleos da rafe e de projeções colinérgicas oriundas dos núcleos da região septal. A serotonina é um neurotransmissor sintetizado principalmente pelos núcleos da rafe e possui papel chave no comportamento de sono e alerta em situações normais, assim como atua em situações de distúrbios afetivos como depressão e ansiedade (Waselus, Valentino e Van Bockstaele, 2011). Dentre as regiões 
encefálicas produtoras de serotonina, destacamos o núcleo dorsal da rafe (DR) que possui cerca de 50-60\% de todos os neurônios encefálicos produtores de serotonina. Estudos neuroanatômicos têm evidenciado que os neurônios deste núcleo que são imunorreativos a serotonina também possuem terminais positivos para o CRF. Além disso, foi verificado que a expressão de fos induzida por CRF i.c.v foi modulada no DR após administração de TCAP-1 i.c.v sugerindo a participação deste peptídeo em áreas associadas com resposta ao estresse (Jacobs e Azmitia, 1992; Gonçalvez et al., 2009; Tan et al., 2009; Waselus, Valentino e Van Bockstaele , 2011). Estes estudos contribuem para uma possível participação de TCAP-1 em vias serotoninérgicas responsáveis pela modulação e resposta a ansiedade. A possível contribuição do TCAP-1 em vias serotoninérgicas é plausível devido os resultados de distribuição de TCAP-1 no encéfalo do Cebus apella constatar a presença deste peptídeo nos núcleos da rafe e em vias de projeção serotoninérgica. Porém, futuros estudos de colocalização entre TCAP-1 e serotonina seriam de grande valia para elucidar e melhor confirmar a participação deste peptídeo na via serotoninérgica.

Outros resultados advindos do mapeamento do TCAP-1 no encéfalo do Cebus apella demonstraram que este peptídeo está presente em núcleos com células metabolizadoras de acetilcolina e noradrenalina, que como veremos participa, juntamente com a dopamina e a serotonina, das vias de modulação da ansiedade e estresse. A distribuição de TCAP-1 no Cebus apella foi encontrada nos núcleos colinérgicos da região septal, como o núcleo horizontal da banda diagonal (HDB), o no núcleo basal (Meynert) (B) e o núcleo septal medial (MS). Estes núcleos em associação com outros núcleos da mesma região, apresentam importante função na memória, atenção, motivação e cognição (Mufson et al., 2003; Hong e Jang, 2010). Estudos têm evidenciado a participação do sistema colinérgico em desordens de humor sendo notada a hiperatividade deste sistema em pacientes depressivos (Janowsky e Overstreet, 1995; Drevets, Price e Furey, 2008). A noradrenalina, oriunda principalmente do núcleo locus coeruleus (LC), projeta-se para todo o córtex cerebral e para áreas límbicas apresentando importante papel na regulação de distúrbios do humor como a depressão (Graeff, 1993). O LC é considerado a região chave do tronco encefálico envolvido na resposta de alerta ao estímulo estressor por ativar o eixo hipotálamo-hipófise-adrenal em situações de estresse agudo (Ziegler, Cass e Herman, 1999). Como verificado, a presença de TCAP-1 no LC e em núcleos colinérgicos do Cebus apella reforça a provável participação deste peptídeo em vias associadas com a regulação do humor, porém, como já descrito, acreditamos que 
futuros estudos, entre eles o de co-localização de TCAP-1 com os clássicos mediadores do SNC, contribuirão para confirmação funcional do TCAP-1 em vias de controle da emoção.

O córtex pré-frontal atua na circuitaria neuronal associada com as desordens de humor sendo notado que tanto a divisão medial quanto a lateral possuem participação nos sintomas da depressão, porém, com distintos papéis devido às diferentes conexões dentro do SNC (Koenigs e Grafman, 2009; Prince e Dravets, 2010). Resumidamente, a divisão lateral é associada com funções cognitivas e de execução devido às suas conexões com a área pré-motora e córtex parietal (Koenigs e Grafman, 2009; Ray e Zald, 2011). A divisão medial tem sido associada com funções emocionais e afetivas devido às suas conexões com núcleos hipotalâmicos e amígdala através de circuitos clássicos descritos nas desordens de humor (circuito cortico-tálamo-límbico e/ou circuito cortico-estriato-pálidotalâmico-límbico) (Soares e Mann, 1997; Price e Drevets, 2010). Também foi verificado que algumas áreas do córtex pré-frontal medial possuem projeções direta para a amígdala como constatado na área 9 do córtex pré-frontal (Aggleton et al., 1980; Stefanacci e Amaral, 2002). Além disso, o córtex pré-frontal também estabelece conexão direta com núcleos hipotalâmicos como o hipotálamo posterior e lateral e conexão indireta (via núcleos hipotalâmicos descritos) com núcleos autonômicos do tronco encefálico como a formação reticular, núcleo parabraquial, núcleos da rafe e substância cinzenta periaqueductal (RempelClower e Barbas, 1998; Ongür, An e Price, 1998; Barbas et al., 2003; Ray e Zald, 2011). Portanto, a via descendente córtex pré-frontal/hipotálamo/tronco encefálico pode influenciar o sistema nervoso autônomo durante situações emocionais (Barbas et al., 2003). Interessante que a imunorreatividade e a distribuição do RNAm para TCAP-1 foi verificada em corpos neuronais da divisão lateral e medial do córtex pré-frontal, incluindo a área 9, assim como nos núcleos pertecentes ao circuitos de projeções do córtex pré-frontal como amígdala (central e medial), hipotálamo (posterior e lateral) e núcleos autonômicos do tronco encefálico (como formação reticular e núcleos da rafe) sendo portanto sugestivo a participação do TCAP-1 na modulação da via do córtex pré-frontal e consequentemente na regulação das respostas comportamentais associada ao estresse. Essa suposição é reforçada devido estudos com administração de CRF i.c.v em ratos verificarem que a expressão de fos induzida por CRF i.c.v foi atenuada no córtex pré-frontal medial e no núcleo central da amígdala após administração de TCAP-1 i.c.v (Tan et al., 2009). 
Além disso, o núcleo motor dorsal do nervo vago, outro núcleo envolvido com a neurocircuitaria das respostas autonômicas, apresentou imunorreatividade e a expressão do RNAm para TCAP-1. Este núcleo está envolvido no controle e na resposta comportamental autonômica associado à emoção devido os núcleos $\mathrm{Ce}$ e Me estarebelecerem conexões com este e com outros núcleos autonômicos presente no tronco encefálico (Price e Drevets, 2010). Desta maneira, o desequilíbrio autonômico verificado em pacientes depressivos pode ser reflexo da disfunção do circuito neuronal que tem nos núcleos do complexo amigdalóide, em especial o núcleo central e medial da amígdala, o centro regulador das respostas autonômicas associada à emoção (Drevets, Prince e Furey, 2008).

Dentre as áreas límbicas nas quais foram encontrados o RNAm e o peptídeo TCAP-1 no Cebus apella, a formação hipocampal é a que apresenta singularidade. Isto se deve aos estudos in vitro que demonstraram a atuação do TCAP-1 na morfologia dendrítica de neurônios hipocampais devido a regulação de proteínas do citoesqueleto (Al Chawaf et al., 2007a). Estudos in vivo verificaram que TCAP-1 exerce papel modulatório em situações de estresse possivelmente por bloquear a atuação do CRF no hipocampo ou em outras áreas límbicas ou por regular a remodelação de redes neuronais como verificado in vitro uma vez que neurônios piramidais do hipocampo apresentam elevada neuroplasticidade frente a estímulos estressores ou de aprendizagem (Mahajane e Desiraju,1988; Watanabe, Gould e McEwen, 1992; Wang et al., 2005; Al Chawaf et al., 2007a; Tan et al., 2008; Tan et al., 2009).

Os resultados de distribuição do TCAP-1 na região talâmica do Cebus apella tem mostrado distribuição na maioria dos grupos nucleares talâmicos, incluindo núcleos do grupo talâmico mediodorsal e anterior. Funcionalmente os núcleos talâmicos constituem o principal centro de transmissão de informações sensoriais, motoras, aprendizado, memória e emoção dentro SNC (Herrero, Barcia e Navarro, 2002). A participação das áreas talâmicas, em especial núcleo talâmico mediodorsal, nos circuitos neuroanatômicos da depressão tem mostrado que este é um centro integrador das respostas emocionais via circuito corticotálamo-límbico e/ou via circuito cortico-estriato- pálido-talâmico-límbico (Drevets e Raichle, 1992). Com base em nossos resultados podemos sugerir uma possível participação de TCAP1 nas inúmeras informações que trafegam pelos núcleos talâmicos e em especial nas informações associadas com a emoção. 
Resultados de distribuição do TCAP-1 foram verificados nos neurônios do córtex cerebelar, principalmente na camada de células e Purkinje (Pk) e nos núcleos do cerebelo. A imunorreatividade também esteve presente em células fusiformes contidas na camada granular do cerebelo $(\mathrm{GrCb})$ e logo abaixo dos corpos neuronais das células de Purkinje. Devido a localização e morfologia destas células acreditamos ser as células de Lugaro que são uma nova classe de interneurônios inibitórios, pouco numerosos (as células de Lugaro podem fazer sinapse com mais de 100 células de Golgi) e presentes na GrCb, responsáveis pela a sincronização da atividade das células de Golgi (Sotelo, 2011). Assim, para melhor identificar se TCAP-1 está realmente nas células de Lugaro seria de grande valia futuros estudos de colocalização de glicina e GABA que são mediadores presentes nestes interneurônios e que já foram descritos no cortex cerebelar de primatas não-humano (Crook et al., 2006). Funcionalmente o cerebelo, além de classicamente estar envolvido no processamento motor, também atua em funções não motoras como processamento e modulação nociceptivo, cognição e modulação das emoções (Dickson et al., 2010; Moulton et al., 2010; Stoodley e Schmahmann, 2010; Bauer, Kerr e Swain, 2011). A redução da nocicepção foi verificada em primatas não-humano e roedores, através da aplicação de estímulos elétricos e farmacológicos na região cortical do cerebelo (lobo anterior) e do núcleo cerebelar medial em ratos (Siegel e Wepsic, 1974; Saab e Willis, 2003). Também é notado em estudos de neuroimagem funcional que durante o processo nociceptivo ocorre ativação dos núcleos do cerebelo e de regiões cerebelares corticais, como o lóbulo cerebelar VI que é descrito como área de integração sensório-motora, além do lóbulo Crus I e Crus II que estão associados com a cognição (Moulton et al., 2010). Outra atuação não motora descrita para o cerebelo é a regulação do comportamento emocional devido à existência de conexões com o sistema límbico em especial com amígdala, hipocampo e região septal (Bauer, Kerr e Swain, 2011; Turner et al, 2007). Essa modulação comportamental foi observada em pacientes que apresentaram mudança de personalidade após lesões no lobo posterior e no verme do cerebelo (Schmahmann e Sherman, 1998). Em virtude destas funções não motoras atribuídas ao cerebelo, descritas tanto para sua porção cortical quanto para os núcleos, é plausível sugerir uma possível participação do TCAP-1 no que se refere a modulação do comportamento emocional uma vez que este peptídeo encontra-se distribuído tanto em regiões corticais e dos núcleos cerebelares do primata não-humano Cebus apella. Além disso, os animais que receberam injeções de TCAP-1 (i.c.v ou endovenoso) não apresentaram significantes 
alterações de motricidade. Consequentemente, pode ser sugerido que a distribuição desse peptídeo no cerebelo do Cebus apella pode contribuir para a função límbica verificada nesta região encefálica. Ressaltamos que embora seja descrito a atuação do cerebelo no comportamento emocional, os estudos utilizados como referência sugerem estudos complementares a fim de confirmar o papel de cada região cerebelar na atuação não motora.

Os resultados de distribuição do peptídeo TCAP-1 foi constado em muitas outras regiões encefálicas. A ampla distribuição neuroanatômica do TCAP-1 no SNC do primata não-humano Cebus apella em regiões associadas com vias autonômicas, sensoriais, motoras e do comportamento emocional sugere que este peptídeo possa estar atuando na complexa resposta verificada em situações de desordem de humor como depressão e ansiedade através da modulação, direta ou indireta, destas respostas.

\subsection{Considerações sobre a distribuição de TEN 1/TCAP-1 em primatas não-humanos (Cebus apella)}

Este trabalho realizou mapeamento sistematizado no SNC do peptídeo TCAP-1 devido à sua importância funcional no controle comportamental e a carência de estudos neuroanatômicos que pudessem suportar estas funções. Porém, também foi realizado a descrição da TEN1 em cortes representativos do SNC para constatar se a distribuição de TCAP-1/TEN1 encontra-se em regiões neuroanatômicas distintas como descrito na literatura (Wang et al., 2005). Os resultados desta análise mostram que a diferença entre TCAP-1 e TEN1, aparentemente, se encontram no padrão de marcação e não na distribuição neuroanatômica que tem se mostrado correspondente em muitas regiões encefálicas colaborando com os estudos atuais de Chand, 2011a; 2011 b (em fase de elaboração) ${ }^{5}$.

\footnotetext{
${ }^{5}$ Chand D, Al Chawaf A, Tan LA, Ng T, Casatti C, Song L, Kollara A, Brown T, Rotzinger S, Belsham DD, Boutros P, Vaccarino FJ, Barsyte-Lovejoy D, Lovejoy DA. C-terminal region of teneurin-1 in mouse hippocampus: Cellular and tissue locations, binding site and regulation of dendritic arborization. Journal of Neuroscience.2011a.

${ }^{5}$ Chand D, Song L, Casatti C, Kollara A, Barsyte-Lovejoy D, Ackloo S, Boutros PC, Evans K, Brown TJ, Belsham DD, Lovejoy DA. C-terminal region of teneurin-1 co-localizes with dystroglycan and modulates hippocampal neurite outgrowth through ERK-dependent stathmin and filamin A modulation of the cytoskeleton. Journal of Neuroscience;Development/Plasticity/Repair.2011b.
} 
A distribuição da TEN 1 no SNC por meio da técnica de imuno-histoquímica e a co-localização da TEN 1/TCAP-1 através da dupla imunofluorescência foram realizados em cortes histológicos do SNC adjacente aos utilizados para TCAP-1. A distribuição da TEN 1 foi encontrada nos núcleos do cerebelo desse primata não-humano (Med e Lat) coincidindo com os dados prévios de Oohashi (1999) e Zhou (2003) que verificaram tal proteína nos núcleos do cerebelo de roedores adultos porém sem descrever os núcleos específicos. Quanto ao córtex cerebelar do Cebus apella foi encontrado evidência desta proteína na camada de Purkinje do cerebelo coincidindo com o estudo feito em aves (Kenzelmann et al., 2008) e diferindo dos estudos em roedores que verificaram a presença da TEN 1 na camada granular e molecular do cerebelo (Oohashi et al., 1999; Zhou et al., 2003). Algumas regiões encefálicas relacionadas com o processamento sensorial apresentaram TEN 1-ir, tais como o núcleo geniculado lateral dorsal (DLG) e o núcleo coclear dorsal (DC) que participam da via visual e auditiva, respectivamente. Estudos anteriores feitos em aves verificaram a presença do RNAm e da proteína TEN 1 em regiões e núcleos do SNC que participam das vias de processamento visual como retina, tecto óptico do mesencéfalo e núcleo rotundo do tálamo; vias de processamento auditivo como os núcleos laminaris e magnocelularis e vias de processamento olfatório como o bulbo olfatório e córtex piriforme (Minet, Rubin et al., 1999; Rubin, Tucker et al., 1999; Kenzelmann, Chiquet-Ehrismann et al., 2008). Em embriões de drosófilas a distribuição da TEN 1 também tem sido constatada nos neurônios do sistema visual (Baumgartner, 1994; Minet, Rubin et al., 1999). Até o momento, os resultados mostraram a conservação da proteína TEN 1 no SNC do Cebus apella, principalmente em regiões envolvidas com vias sensoriais.

Desta forma, a distribuição neuroanatômica da TEN 1 e TCAP-1 no SNC do Cebus apella apresentou correspondência em algumas regiões encefálicas porém com padrão de imunomarcação característico para cada sistema, sendo que a imunorreatividade para TCAP-1 encontra-se predominante no citosol e TEN 1 na membrana plasmática colaborando com recentes estudos realizados por Chand, 2011a;2011b (em fase de elaboração) ${ }^{6}$. Além

\footnotetext{
${ }^{6}$ Chand D, Al Chawaf A, Tan LA, Ng T, Casatti C, Song L, Kollara A, Brown T, Rotzinger S, Belsham DD, Boutros P, Vaccarino FJ, Barsyte-Lovejoy D, Lovejoy DA. C-terminal region of teneurin-1 in mouse hippocampus: Cellular and tissue locations, binding site and regulation of dendritic arborization. Journal of Neuroscience.2011a.

${ }^{6}$ Chand D, Song L, Casatti C, Kollara A, Barsyte-Lovejoy D, Ackloo S, Boutros PC, Evans K, Brown TJ, Belsham DD, Lovejoy DA. C-terminal region of teneurin-1 co-localizes with dystroglycan and modulates
} 
disso, é notado que TCAP-1 é funcionalmente e estruturalmente distinto da TEN 1 (Chand, 2011 b, em fase de elaboração) ${ }^{6}$ sendo possível sugerir que embora haja correspondência de distribuição de ambos os sistemas no SNC do Cebus apella, estes possam exercer distintos papéis dentro do SNC.

Devido a expressão da TEN-1 em tecidos não neuronais e principalmente neuronais durante a fase embrionária, alguns autores sugerem a importância desta proteína para o desenvolvimento; porém, o papel funcional da TEN-1 durante a fase adulta ainda é pouco conhecida embora seja notado a presença desta no SNC de animais adultos (Tucker e Chiquet-Ehrismann, 2006; Tucker et al., 2007). Estudos sugerem que na fase adulta a TEN 1 possivelmente atuaria na manutenção dos neurônios adultos e de suas conexões axonais bem como na regeneração neuronal pós-lesão (Kenzelmann, Chiquet-Ehrismann e Tucker, 2007). Por outro lado, o TCAP-1 se mostraria como um neuromediador que atuaria como modulador das respostas comportamentais associada ao sistema límbico, através de uma via secretora regulatória; além de um modulador neuroprotetor liberado durante alterações teciduais potencialmente capazes de resultar em morte neuronal (Wang et al., 2005; Al Chawaf et al., 2007; Tan et al., 2008; 2009).

hippocampal neurite outgrowth through ERK-dependent stathmin and filamin A modulation of the cytoskeleton. Journal of Neuroscience;Development/Plasticity/Repair.2011b. 
7 CONCLUSÕES 
Com base em nossos resultados podemos concluir que:

1. A expressão do RNAm e a presença do peptídeo TCAP-1 no SNC de Cebus apella encontram-se em áreas que estão associadas direta ou indiretamente com a modulação da resposta ao estresse e ansiedade assim como em áreas responsáveis pelo controle motor, sensorial e autonômico;

2. TEN 1 e TCAP-1 apresentam correspondência de distribuição em várias áreas encefálicas; entretanto com padrão de imunomarcação celular distinto;

3. Os sistemas peptidérgicos TCAP-1 e TEN 1 mostra-se conversado entre as espécies. 


\section{REFERÊNCIAS}

Aggleton JP, Burton MJ, Passingham RE. Cortical and subcortical afferents to the amygdala of the rhesus monkey (Macaca mulatta). Brain Res. 1980;190:347-68.

Al Chawaf, A, St Amant K,Belsham D, Lovejoy DA. Regulation of neurite growth in immortalized mouse hypothalamic neurons and rat hippocampal primary cultures by teneurin C-terminal-associated peptide-1. Neuroscience. 2007a;144:1241-54.

Al Chawaf A, Xu K, Tan LA, Vaccarino FJ, Lovejoy DA, Rotzinger S. Corticotropinreleasing factor (CRF)-induced behaviors are modulated by intravenous administration of teneurin C-terminal associated peptide-1 (TCAP-1). Peptides. 2007b;28:1406-15.

Arborelius L, Owens MJ, Plotsky PM, Nemeroff CB. The role of corticotropin-releasing factor in depression and anxiety disorders. J Endocrinol. 1999;160:1-12.

Bagutti C, Forro G,Ferralli J, Rubin B, Chiquet-Ehrismann R. The intracellular domain of teneurin-2 has a nuclear function and represses zic-1-mediated transcription. J Cell Sci. 2003;116:2957-66.

Baldi E, Bucherelli C. Substantia nigra, nucleus basalis magnocellularis and basolateral amygdala roles in extinction of contextual fear conditioning in the rat. Neurobiol Learn Mem. 2010;94:199-205.

Baldi E, Mariottini C, Bucherelli C. Substantia nigra role in fear conditioning consolidation. Neurobiol Learn Mem. 2007;87:133-139.

Barbas H, Saha S, Rempel-Clower N, Ghashghaei T. Serial pathways from primate prefrontal cortex to autonomic areas may influence emotional expression. BMC Neurosci. 2003;10:4-25.

Bauer DJ, Kerr AL, Swain RA. Cerebellar dentate nuclei lesions reduce motivation in appetitive operant conditioning and open field exploration. Neurobiol Learn Mem. 2011;95:166-175. 
Baumgartner S, Chiquet-Ehrismann R. Ten a, a Drosophila gene related to tenascin, shows selective transcript localization. Mech Dev. 1993;40:165-176.

Baumgartner S, Martin D, Hagios C, Chiquet-Ehrismann R. Ten m, a Drosophila gene related to tenascin, is a new pair-rule gene. EMBO J. 1994;13:3728-40.

Burry RW. Controls for Immunocytochemistry: An Update. J Histochem Cytochem. 2011;59:6-12.

Buwalda B, Van Kalkeren AA, de Boer SF, Koolhaas JM. Behavioral and physiological consequences of repeated daily intracerebroventricular injection of corticotropin-releasing factor in the rat. Psychoneuroendocrinology. 1998;23:205-218.

Carrasco, GA, Van de Kar, LD. Neuroendocrine pharmacology of stress. Eur J Pharmacol. 2003;463:235-72.

Carvalho-Barros RA. Estudo anatômico do plexo lombar, sacral e coccígeo do macaco Cebus apella - origem, composição e nervos resultantes. [dissertação (Mestrado em Anatomia dos Animais Domésticos)]. São Paulo (Brasil): Faculdade de Medicina Veterinária e Zootecnia da Universidade de São Paulo; 2002.

Conejo NM, González-Pardo H, López M, Cantora R, Arias JL. Induction of c-Fos expression in the mammillary bodies, anterior thalamus and dorsal hippocampus after fear conditioning. Brain Res Bull. 2007;74:172-77.

Coons AH, Creech HJ, Jones RN, Berliner E. The demonstration of pneumococcal antigen in tissues by the use of fluorescent antibody. J Immunol. 1942;45:159-70.

Crook J, Hendrickson A, Robinson, FR. Co-localization of glycine and gaba immunoreactivity in interneurons in Macaca monkey cerebellar cortex. Neuroscience. 2006; 141:1951-9.

Crosby ECH, Humphrey T, Lauer EW. Correlative Anatomy of nervous system. New York: Macmillan Company; 1962. 
Dickson PE, Rogers TD, Del Mar N, Martin LA, Heck D, Blaha CD, Goldowitz D, Mittleman G. Behavioral flexibility in a mouse model of developmental cerebellar Purkinje cell loss. Neurobiol Learn Mem. 2010;94:220-28.

Drabikowski K, Trzebiatowska A, Chiquet-Ehrismann R. Ten-1, an essential gene for germ cell development, epidermal morphogenesis, gonad migration, and neuronal pathfinding in Caenorhabditis elegans. Dev Biol. 2005;282:27-38.

Drevets WC, Price JL, Furey ML. Brain structural and functional abnormalities in mood disorders: implications for neurocircuitry models of depression. Brain Struct Funct. 2008;213:93-118.

Drevets WC, Raichle ME. Neuroanatomical circuits in depression: implications for treatment mechanisms.Psychopharmacol Bull. 1992;28:261-74.

Eidelberg E, Saldias CA. A stereotaxic atlas for Cebus monkeys. J Comp Neurol. 1960;115:103-23.

Fascetti N, Baumgartner S. Expression of Drosophila Ten-a, a dimeric receptor during embryonic development. Mech Dev. 2002;114:197-200.

Gelowitz DL, Kokkinidis L. Enhanced amygdala kindling after electrical stimulation of the ventral tegmental area: implications for fear and anxiety. J Neurosci. 1999; 19:RC41.

Gonçalves L, Nogueira MI, Shammah-Lagnado SJ, Metzger M. Prefrontal afferents to the dorsal raphe nucleus in the rat. Brain Res Bull. 2009;78:240-47.

Graeff, FG. Role of 5-HT in defensive behavior and anxiety. Rev Neurosci. 1993;4:181-82.

Haber SN, Groenewegen HJ, Grove EA, Nauta WJ. Efferent connections of the ventral pallidum: evidence of a dual striato pallidofugal pathway. J Comp Neurol. 1985;235:322-35.

Herrero MT, Barcia C, Navarro JM. Functional anatomy of thalamus and basal ganglia. Childs Nerv Syst. 2002;18:386-404.

Hill WCO. Primates: comparative anatomy and taxonomy.. UK: Edinburgh at the University Press; 1960. vol. 2. [s.p.] 
Hoffman GE, Le WW, Sita LV. The importance of titrating antibodies for immunocytochemical methods. Curr Protoc Neurosci. 2008;45:2.12.1-2.12.26.

Holmseth S, Lehre KP, Danbolt NC. Specificity controls for immunocytochemistry. Anat Embryol (Berl). 2006;211:257-66.

Hong JH, Jang SH. Neural pathway from nucleus basalis of Meynert passing through the cingulum in the human brain. Brain Res. 2010;1346:190-4.

Jacobs BL, Azmitia EC. Structure and function of the brain serotonin system. Physiol Rev. 1992;72:165-229.

Janowsky DS, Overstreet DH. The role of acetylcholine mechanisms in mood disorders. Raven Press. 1995.

Kataoka Y, Shibata K, Gomita Y, Ueki S. The mammillary body is a potential site of antianxiety action of benzodiazepines. Brain Res. 1982;241:374-77.

Kenzelmann D, Chiquet-Ehrismann R, Leachman NT, Tucker RP. Teneurin-1 is expressed in interconnected regions of the developing brain and is processed in vivo. BMC Dev Biol. 2008;8:30-44.

Kenzelmann D, Chiquet-Ehrismann R, Tucker RP. Teneurins, a transmembrane protein family involved in cell communication during neuronal development. Cell Mol Life Sci. 2007; 64:1452-56.

Kinel-Tahan Y, Weiss H, Dgangy O, Levine A, Wides R. Drosophila odz gene is required for multiple cell types in the compound retina. Dev Dyn. 2007;236:2541-54.

Koenigs M, Grafman J. The functional neuroanatomy of depression: distinct roles for ventromedial and dorsolateral prefrontal cortex. Behav Brain Res. 2009;201:239-243.

Kupferschmidt DA, Lovejoy DA, Rotzinger S, Erb S. Teneurin C-terminal associated peptide-1 blocks the effects of corticotropin-releasing factor on reinstatement of cocaine seeking and on cocaine-induced behavioural sensitization. Br J Pharmacol. 2011;162:574-83.

Le Jeune F, Péron J, Grandjean D, Drapier S, Haegelen C, Garin E, Millet B, Vérin M. Subthalamic nucleus stimulation affects limbic and associative circuits: a PET study. Eur J Nucl Med Mol Imaging. 2010;37:1512-20. 
Leamey CA, Glendining KA, Kreiman G, Kang ND, Wang KH, Fassler R, Sawatari A, Tonegawa S, Sur M. Differential gene expression between sensory neocortical areas: potential roles for Ten_m3 and Bc16 in patterning visual and somatosensory pathways. Cereb Cortex. 2008;18:53-66.

Levine A, Bashan-Ahrend A, Budai-Hadrian O, Gartenberg D, Menasherow S, Wides R. Odd Oz: a novel Drosophila pair rule gene. Cell. 1994;77:587-98.

Levine A, Weiss C,Wides R. Expression of the pair-rule gene odd Oz (odz) in imaginal tissues. Dev Dyn. 1997;209:1-14.

Lossie AC, Nakamura H, Thomas SE, Justice MJ. Mutation of 17Rn3 shows that Odz4 is required for mouse gastrulation. Genetics. 2005;169:285-99.

Lovejoy DA, Al Chawaf A, Cadinouche MZ. Teneurin C-terminal associated peptides: an enigmatic family of neuropeptides with structural similarity to the corticotropin-releasing factor and calcitonin families of peptides. Gen Comp Endocrinol. 2006a;148:299-305.

Lovejoy DA, Jahan S. Phylogeny of the corticotropin-releasing factor family of peptides in the metazoa. Gen Comp Endocrinol. 2006b;146:1-8.

Lovejoy DA, Rotzinger S, Lovejoy-Barsyte D. Evolution of complementary peptide systems: teneurin C-terminal-associated peptides and corticotropin-releasing factor superfamilies. Ann N Y Acad Sci. 2009a;1163:215-20.

Lovejoy, DA. Structural evolution of urotensin-I: reflections of life before corticotropin releasing factor. Gen Comp Endocrinol. 2009b;164:15-19.

Lucas JM, Ji Y, Masri R. Motor cortex stimulation reduces hyperalgesia in an animal model of central pain. Pain. 2011;152:1398-1407.

Mahajan DS, Desiraju T. Alterations of dendritic branching and spine densities of hippocampal CA3 pyramidal neurons induced by operant conditioning in the phase of brain growth spurt. Exp Neurol. 1988;100:1-15. 
Manocha S, Shantha Tr, Bourne Gh. A stereotaxic atlas of the brain of the cebus monkey (Cebus apella). London: Oxford University Press. 1968. 97 p.

Masri R, Quiton RL, Lucas JM, Murray PD, Thompson SM, Keller A. Zona incerta: a role in central pain. J Neurophysiol. 2009;102:181-91.

Minet AD, Chiquet-Ehrismann R. Phylogenetic analysis of teneurin genes and comparison to the rearrangement hot spot elements of E. coli. Gene. 2000;257:87-97.

Minet AD, Rubin BP, Tucker RP, Baumgartner S, Chiquet-Ehrismann R.. Teneurin-1, a vertebrate homologue of the Drosophila pair-rule gene ten-m, is a neuronal protein with a novel type of heparin-binding domain. J Cell Sci. 1999;112:2019-32.

Moulton EA, Schmahmann JD, Becerra L, Borsook D. The cerebellum and pain: passive integrator or active participator?. Brain Res Rev. 2010;65:14-27.

Mufson EJ, Ginsberg SD, Ikonomovic MD, DeKosky ST. Human cholinergic basal forebrain: chemoanatomy and neurologic dysfunction. J Chem Neuroanat. 2003;26:233-42.

Nagle CA, Denari JH. The reproductive biology of capuchin monkey (Cebus spp): International Zoo Yerbook. 1982. [s.p.]

Nunes SM, Ferralli J, Choi K, Brown-Luedi M, Minet AD, Chiquet-Ehrismann R. The intracellular domain of teneurin-1 interacts with MBD1 and CAP/ponsin resulting in subcellular codistribution and translocation to the nuclear matrix. Exp Cell Res. 2005;305:122-32.

Ongür D, An X, Price JL. Prefrontal cortical projections to the hypothalamus in macaque monkeys. J Comp Neurol. 1998;401:480-505.

Oohashi T, Zhou XH, Feng K, Richter B, Morgelin M, Perez MT, Su WD, ChiquetEhrismann R, Rauch U, Fassler R. Mouse ten-m/Odz is a new family of dimeric type II transmembrane proteins expressed in many tissues. J Cell Biol. 1999;145:563-77. 
Paxinos G, Mai JK. The Human Nervous System. 2th ed. Elsevier Academic Press; 2004.

Paxinos G, Xu-Feng H, Petrides M, Toga AW. The Rhesus Monkey Brain in stereotaxic coordinates. 2th ed. London Academic Press; 2009. 416 p.

Pezze MA, Feldon J. Mesolimbic dopaminergic pathways in fear conditioning. Prog Neurobiol. 2004;74:301-20.

Price JL, Drevets WC. Neurocircuitry of Mood Disorders. Neuropsychopharmacology. 2010;35:192-216.

Qian X, Barsyte-Lovejoy D, Wang L, Chewpoy B, Gautam N, Al Chawaf A, Lovejoy DA. Cloning and characterization of teneurin C-terminus associated peptide (TCAP)-3 from the hypothalamus of an adult rainbow trout (Oncorhynchus mykiss). Gen Comp Endocrinol. 2004;137:205-16.

Ray RD, Zald DH. Anatomical insights into the interaction of emotion and cognition in the prefrontal cortex. Neurosci Biobehav Rev. 2011 (in press).

Rempel-Clower NL, Barbas H. Topographic organization of connections between the hypothalamus and prefrontal cortex in the rhesus monkey. J Comp Neurol. 1998;398:393-419.

Rosene DL, Roy NJ, Davis BJ. A cryoprotection method that facilitates cutting frozen sections of whole monkey brains for histological and histochemical processing without freezing artifact. J Histochem Cytochem. 1986;34:1301-15.

Rothwell NJ. Central effects of CRF on metabolism and energy balance. Neurosci Biobehav Rev. 1990;14:263-71.

Rotzinger S, Lovejoy DA, Tan LA. Behavioral effects of neuropeptides in rodent models of depression and anxiety. Peptides. 2010;31:736-56.

Rubin BP, Tucker RP, Brown-Luedi M, Martin D, Chiquet-Ehrismann R. Teneurin 2 is expressed by the neurons of the thalamofugal visual system in situ and promotes homophilic cell-cell adhesion in vitro. Development. 2002;20:4697-05. 
Rubin BP, Tucker RP, Martin D, Chiquet-Ehrismann R. Teneurins: a novel family of neuronal cell surface proteins in vertebrates, homologous to the Drosophila pair-rule gene product Ten-m. Dev Biol. 1999;216:195-209.

Saab CY, Willis WD. The cerebellum: organization, functions and its role in nociception. Brain Res Brain Res Rev. 2003;42:85-95.

Saper CB, Akil H, Watson SJ. Lateral hypothalamic innervation of the cerebral cortex: immunoreactive staining for a peptide resembling but immunochemically distinct from pituitary/arcuate alpha-melanocyte stimulating hormone. Brain Res Bull. 1986;16:107-120.

Saper CB, Sawchenko PE. Magic peptides, magic antibodies: guidelines for appropriate controls for immunohistochemistry. J Comp Neurol. 2003;465:161-3.

Schmahmann JD, Sherman JC. The cerebellar cognitive affective syndrome. Brain. 1998;121:561-79.

Siegel P, Wepsic JG. Alteration of nociception by stimulation of cerebellar structures in the monkey.Physiol Behav. 1974;13:189-94.

Soares JC, Mann JJ. The functional neuroanatomy of mood disorders. J Psychiat Res. 1997;31:393-432.

Sociedade Brasileira de Anatomia. Terminologia Anatômica. 1ed. São Paulo: Manole; 2001. 248 .

Sotelo C. Camillo Golgi and Santiago Ramon y Cajal: the anatomical organization of the cortex of the cerebellum. Can the neuron doctrine still support our actual knowledge on the cerebellar structural arrangement? Brain Res Rev. 2011;66:16-34.

St John JL, Rosene DL, Luebke JI. Morphology and Electrophysiology of Dentate Granule Cells in the Rhesus Monkey: Comparison with the Rat. J Comp Neurol. 1997;387:136-47.

Stefanacci L, Amaral DG. Some observations on cortical inputs to the macaque monkey amygdala: an anterograde tracing study. J Comp Neurol. 2002;451:301-23.

Stoodley CJ, Schmahmann JD. Evidence for topographic organization in the cerebellum of motor control versus cognitive and affective processing. Cortex. 2010;46:831-44. 
Tan LA, Xu K, Vaccarino FJ, Lovejoy DA, Rotzinger S. Repeated intracerebral teneurin Cterminal associated peptide (TCAP)-1 injections produce enduring changes in behavioral responses to corticotropin-releasing factor (CRF) in rat models of anxiety. Behav Brain Res. 2008; 188:195-200.

Tan LA, Xu K, Vaccarino FJ, Lovejoy DA, Rotzinger S. Teneurin C-terminal associated peptide (TCAP)-1 attenuates corticotropin-releasing factor (CRF)-induced c-Fos expression in the limbic system and modulates anxiety behavior in male Wistar rats. Behav Brain Res. 2009;201:198-206.

Temel Y. Limbic effects of high-frequency stimulation of the subthalamic nucleus. Vitam Horm. 2010;82:47-63.

Trubiani G, Al Chawaf A, Belsham DD, Barsyte-Lovejoy D, Lovejoy DA. Teneurin carboxy (C)-terminal associated peptide-1 inhibits alkalosis-associated necrotic neuronal death by stimulating superoxide dismutase and catalase activity in immortalized mouse hypothalamic cells. Brain Res. 2007;1176:27-36.

Tucker RP, Chiquet-Ehrismann R. Teneurins: a conserved family of transmembrane proteins involved in intercellular signaling during development. Dev Biol. 2006;290:237-45.

Tucker RP, Kenzelmann D, Trzebiatowska A, Chiquet-Ehrismann R. Teneurins: transmembrane proteins with fundamental roles in development. Int J Biochem Cell Biol. 2007;39:292-97.

Turner BM, Paradiso S, Marvel CL, Pierson R, Boles Ponto LL, Hichwa RD, Robinson RG. The Cerebellum and Emotional Experience. Neuropsychologia. 2007;45:1331-41.

Turner MS, Gray TS, Mickiewicz AL, Napier TC. Fos expression following activation of the ventral pallidum in normal rats and in a model of Parkinson's Disease: implications for limbic system and basal ganglia interactions. Brain Struct Funct. 2008;213:197-213.

Vann SD, Aggleton JP. The mammillary bodies: two memory systems in one? Nat Rev Neurosci. 2004;5:35-44. 
Wang L, Rotzinger S, Al Chawaf A, Elias CF, Barsyte-Lovejoy D, Qian X, Wang NC, De Cristofaro A, Belsham D, Bittencourt JC, Vaccarino F, Lovejoy DA. Teneurin proteins possess a carboxy terminal sequence with neuromodulatory activity. Brain Res Mol Brain Res. 2005;133:253-265.

Waselus M, Valentino RJ, Van Bockstaele EJ. Collateralized dorsal raphe nucleus projections: a mechanism for the integration of diverse functions during stress. J Chem Neuroanat. 2011; 41:266-280.

Wasserman D, Wasserman J, Sokolowski M. Genetics of HPA-axis, depression and suicidality. Eur Psychiatry. 2010;25:278-280.

Watanabe Y, Gould E, McEwen BS. Stress induces atrophy of apical dendrites of hippocampal CA3 pyramidal neurons. Brain Res. 1992;588:341-345.

Young TR, Leamey CA. Teneurins: important regulators of neural circuitry. Int J Biochem Cell Biol. 2009;41:990-993.

Zhou XH, Brandau O, Feng K, Oohashi T, Ninomiya Y, Rauch U, Fassler R. The murine Ten-m/Odz genes show distinct but overlapping expression patterns during development and in adult brain. Gene Expr Patterns. 2003;3:397-405.

Ziegler DR, Cass WA, Herman JP.Excitatory influence of the locus coeruleus in ypothalamicpituitary-adrenocortical axis responses to stress. J Neuroendocrinol. 1999;11:361-369. 